\title{
Removal of Micropollutants by Ozone-Based Processes
}

\author{
Ján Derco ${ }^{1, *} \mathbb{0}$, Andreja Žgajnar Gotvajn ${ }^{2}$, Ol'ga Čižmárová ${ }^{1}$, Jozef Dudáš ${ }^{1}$, Lenka Sumegová ${ }^{3}$ \\ and Katarína Šimovičová ${ }^{3}$ \\ 1 Institute of Chemical and Environmental Engineering, Faculty of Chemical and Food Technology, SUT, \\ Radlinského 9, 81237 Bratislava, Slovakia; olga.cizmarova@stuba.sk (O.Č.); jozef.dudas@stuba.sk (J.D.) \\ 2 Faculty of Chemistry and Chemical Technology, University of Ljubljana, Večna pot 113, \\ SI-1000 Ljubljana, Slovenia; andreja.zgajnar@fkkt.uni-lj.si \\ 3 Water Research Institute, Bratislava, Nábr. arm. gen. L. Svobodu 5, 81249 Bratislava, Slovakia; \\ lenka.sumegova@vuvh.sk (L.S.); katarina.simovicova@vuvh.sk (K.Š.) \\ * Correspondence: jan.derco@stuba.sk; Tel.: +421-2-59325231
}

Citation: Derco, J.; Gotvajn, A.Ž.;

Čižmárová, O.; Dudáš, J.; Sumegová,

L.; Šimovičová, K. Removal of

Micropollutants by Ozone-Based

Processes. Processes 2021, 9, 1013.

https://doi.org/10.3390/pr9061013

Academic Editor: Maria Jose Martin de Vidales

Received: 13 May 2021

Accepted: 4 June 2021

Published: 8 June 2021

Publisher's Note: MDPI stays neutral with regard to jurisdictional claims in published maps and institutional affiliations.

Copyright: (c) 2021 by the authors. Licensee MDPI, Basel, Switzerland. This article is an open access article distributed under the terms and conditions of the Creative Commons Attribution (CC BY) license (https:/ / creativecommons.org/licenses/by/ $4.0 /)$.

\begin{abstract}
Micropollutants and emerging substances pose a serious problem to environmental sustainability and remediation, due to their widespread use and applications in everyday life. This group of chemicals is diverse but with common toxic and harmful properties. Their concentration in the environment is often very low; however, due to their recalcitrant nature, they are persistent in air, water, and soil. From an engineering point of view, the challenge is not straightforward. It is difficult to remove these contaminants from complex mixtures of substances by conventional methods used in wastewater and drinking water treatment. Ozonation and ozone-based AOPs are accepted processes of degradation of resistant substances or at least enhancement of their biodegradability. The aim of this review paper is to present research trends aimed at solving problems in the research and application of ozone-based processes in the removal of micropollutants from wastewater, thus preventing leakage of harmful substances into surface water, soil, and groundwater and facilitating the reuse of wastewater. Priority substances, micropollutants and emerging pollutants, as well as processes and technologies for their transformation and elimination, are briefly specified. Results obtained by the authors in solving research projects that were aimed at eliminating selected micropollutants by ozonation and ozone-based AOPs are also presented. This review focuses on selected alkylphenols, petroleum substances, and organochlorine pesticides.
\end{abstract}

Keywords: biodegradability; combined and integrated processes; ozonation; ozone-based AOPs; micropollutants; persistent pollutants; priority substances; toxicity; wastewater and sludge treatment

\section{Introduction}

The daily use and applications of chemicals, including micropollutants (MP) and so-called emerging substances (ES), have made them ubiquitous in the environment. They belong to a variety of chemical groups and their lists are particularly long.

Micropollutants are characterized by the fact that, despite relatively low concentrations ( $\mu \mathrm{g} \cdot \mathrm{L}^{-1}$ to $\mathrm{ng} \cdot \mathrm{L}^{-1}$ ), they have significant negative effects on ecosystems and humans. These effects may include acute and chronic toxicity, bioaccumulation and bioconcentration in food chains, genotoxicity, or endocrine effects [1]. They are found in aquatic environments all over the world and can have negative effects on plants, animals, and humans.

The EU watch list of potential priority substances that need to be monitored to determine their environmental risk was launched in 2015. A study of Barbosa et al. reviewed data on their worldwide occurrence and options for their removal from an aqueous environment. Emerging pollutants (EPs) and micropollutants (MPs) from the group of pesticides, pharmaceuticals, personal care products, and industrial chemicals have been brought to attention due to their adverse effect on the equilibrium of different environmental compartments [2]. 
In recent years, many substances have been classified as priority hazardous substances because of their potential effects on human health [1,3]. The adoption of the Water Framework Directive [4] represents an instrument that defines and enables the sustainable protection of water resources. The decision of the European Parliament and of the Council [5] established a list of 33 priority substances or groups of substances, including priority hazardous substances, which present a significant risk to water pollution or the aquatic environment, including risks to waters used for the abstraction of drinking water. In the daughter directive [6], the list of priority substances was extended to 45 .

Although there are no legal discharge limits for micropollutants into environment, some regulations have been published in the last year.

Under the Water Framework Directive (WFD), environmental quality standards (EQS) have been established for 45 priority substances and eight other pollutants. When the Directive on Environmental Quality Standards was amended in 2013, a watch list mechanism was established to require temporary monitoring of other substances for which evidence suggested a possible risk to or via the environment, to inform the selection of additional priority substances [2].

The directive [6] also emphasizes the need to develop new technologies for water and wastewater treatment to address the problem of pollution by priority and specific pollutants for river basins. Since conventional urban wastewater treatment plants (WWTPs) are not specially designed and operated to remove residual concentrations of micropollutants, new technologies, such as many advanced oxidation processes (AOPs), have been investigated [7]. Ozonation is now gaining increased attention after its recent application to urban WWTPs in Switzerland [8].

Some of the included substances in the directive [6] belong to persistent organic pollutants and are on the list of the Stockholm convention [9-11]. They are toxic, slowly biodegradable, and accumulative in organisms, as well as terrestrial and aquatic ecosystems. These compounds, in many cases, enter the aquatic ecosystem after their discharge from industry. Some of them are harmful to ecosystems and human health. Due to their bioaccumulation in animal tissues, they undergo bioaccumulation at the top of the food chain.

An emerging task for municipal wastewater treatment plants will be to act as a barrier and to prevent the emission of harmful substances into aquatic environment. Conventional and advanced wastewater treatment processes are designed primarily to eliminate organics and nutrients. However, attention is increasingly being focused on priority and relevant substances and emerging pollutants, since even low concentrations of these substances can have adverse impacts on aquatic ecosystems. Thus, the incapability of biological wastewater treatment to remove hazardous, toxic, and biologically resistant pollutants effectively shows that new treatment processes are needed to be developed [3,12].

Switzerland has already committed to upgrading the technology at many of its sewage treatment plants to cut the most significant point-source discharges of micropollutants to its lakes and rivers. In 2016, a new Swiss law on water protection entered into force with the aim of reducing the discharge of MPs from wastewater treatment plants [13]. The aim is to reduce at least $80 \%$ of the MP discharge into the environment by implementing various post-treatment methods in the sewage plants operations. In the testing phase, several MPs (herbicides and pharmaceuticals) were monitored. Some of these compounds, such as diclofenac and clarithromycin, are on the EU watch list [2]. The problem of pharmaceutical pollution is also being dealt with in Sweden, where the Primozone company received funding (in 2004) for mobile test plant operation at 10 locations in 2014 and 2015. This test plant tested the efficiency of ozonation on the removal of 24 pharmaceutical compounds. The test results showed that the ozonation removed up to $95 \%$ of the pharmaceutical residue using a dose of $5 \mathrm{~g}$ of ozone per cubic meter of water. Of the test compounds, one, diclofenac, is on the EU watch list. This and four others are also among those in the Swiss list of test compounds: carbamazepine, citalopram, hydrochlorothiazide, and metoprolol [8]. A survey and a description of advanced wastewater treatment for of 
pharmaceutical residues and other hazardous substances are available in [14]. With the development of new analytical and instrumental methods and sophisticated equipment that allow the determination of pollutant content at very low concentrations, there has been increased public and professional attention toward micropollutants (MPs) and emerging pollutants (EPs) in the aqueous environment.

Micropollutants enter the environment due to human activity and can be divided into several groups: drugs (human and veterinary), pesticides and biocides (e.g., alachlor, atrazine, dieldrin), personal care products and synthetic fragrances, oil products, and various industrial chemicals and additives [15]. Micropollutants enter municipal wastewater (WW) during bathing, cleaning, or washing, from toilets, and through used and unused pharmaceuticals and medicines. Due to the serious negative effects on the environment, low concentrations, and, in many cases, the complex chemical structure, the issue of MP removal poses an urgent and current challenge for the research of appropriate treatment technologies, aquatic environmental impacts, and pathways of leakage into groundwater sources [12].

Emerging pollutants are defined as synthetic or naturally occurring chemicals that are not routinely monitored in the environment, but which have the potential to enter the environment and cause known or suspected adverse environmental and/or health effects [16]. In several cases, it is known that the release of new pollutants into the environment has been going on for a long time, but they could not be recognized until new detection methods were developed. The synthesis of new chemicals or changes in the use and disposal of existing chemicals can create new sources of emerging pollutants. The vast majority of MPs and EPs are currently not included in routine monitoring programs and their fate, behavior, and ecotoxicological effects are often not well understood. They can be released from point sources of pollution, e.g., from WWTPs in urban or industrial areas, or from diffuse sources through atmospheric deposition or from plant and animal production.

The synthesis of new chemicals or changes in the use and disposal of existing chemicals can create new sources of emerging pollutants [17]. EPs are classified into more than 20 classes related to their origin [18]. In 2012, approximately 143,000 compounds were registered on the European market, many of which end up in the aquatic environment at some point in their life cycle. Most of them are not removed in conventional WWTPs; they can persist or form new products in the aquatic environment via reactions with other anthropogenic or natural compounds such as humic substances under environmental conditions (sunlight etc.), and they can be bioactive and bioaccumulative [19-24].

MPs and EPs are the focus of intensive research on a laboratory, pilot, and operational scale. A list of 242 chemicals was included in [25], of which around $70 \%$ are pharmaceuticals and personal care products and $30 \%$ are industrial products, including perfluorinated compounds, pesticides, herbicides, and food additives. About $70 \%$ of medicines come from households, 20\% from livestock farming, 5\% from hospital WWs, and the remaining 5\% from unspecified sources [26].

Different advanced treatment methods have been applied for the removal and/or destruction of these pollutants in water and wastewater. These include chemical oxidation, adsorption, and membrane filtration. The highly effective method for the removal of a wide spectrum of emerging and hazardous (micro)pollutants is chemical oxidation with the use of ozone, either directly or indirectly. Despite the high removal/degradation efficiency, chemical oxidation methods are relatively expensive for complete mineralization of pollutants, due to the formation of increasingly (bio)resistant oxidation byproducts. However, the combination of chemical oxidation and traditional biological treatment has proven to be an attractive alternative. Ozonation modified in numerous possible ways in a pretreatment process can convert persistent and bioresistant organic compounds into bioavailable intermediates, which would be consequently treated by biological treatment processes. On the other hand, oxidation processes can also be very effective in terms of polishing of final effluent to remove remaining micropollutants and intermediates formed in different treatment stages (Figure 1). 


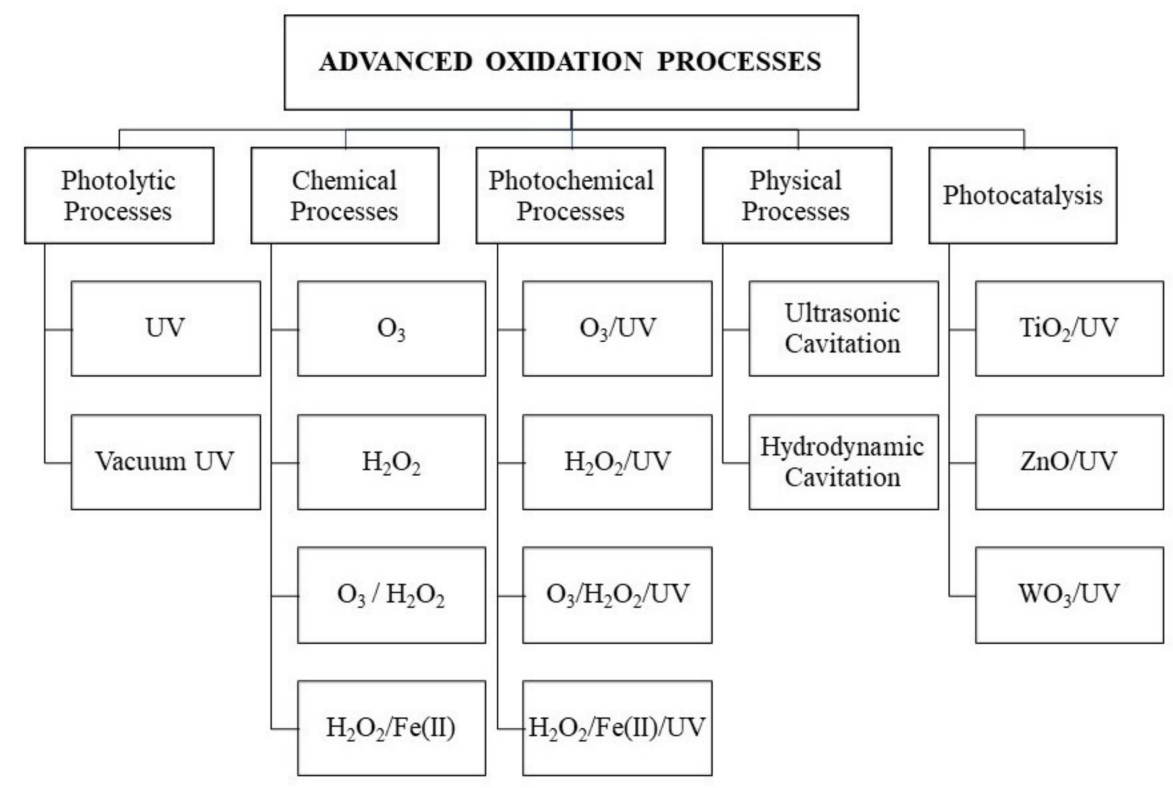

Figure 1. Classification of advanced oxidation processes [27-31].

\section{Ozonation and Ozone-Based Processes}

Ozone reacts easily and nonspecifically with both organic and inorganic compounds due to its high reduction potential (2.07 V vs. SHE) and reactivity [32-34]. It removes odor, colors, COD (chemical oxygen demand), phenols, and cyanides, reduces haze, surfactant, and suspended solid content, and increases the concentration of dissolved oxygen. It is a strong oxidant capable of causing cell lysis and disinfection, reducing the content of suspended solids (SS), and increasing the content of soluble COD $[15,35,36]$.

Ozone targets molecules containing electron-rich moieties (ERMs) such as phenols, olefins, and amines. Ozone can also react via a radical oxidation pathway due to its selfdecomposition in water. Consequently, the effect of ozone and the $\mathrm{HO}^{\bullet}$ (hydroxyl radical) intermediates can achieve high removal efficiencies of micropollutants using low ozone input [36]. Moreover, the transformation products formed upon direct ozonation or indirect radical reaction are less biologically active than the initial compounds [37].

Qiang et al. [38] found ozone-based processes suitable for the degradation of micropollutants present within activated sludge and initiated further research focused on the removal of other compounds adsorbed onto biological sludge.

Ozone is readily produced from air or oxygen using the electric discharge method. A major limitation of the ozonation process is the relatively high cost of its generation [39].

\subsection{Ozone Reactions}

Ozone is a strong oxidant that can react through two different reaction mechanisms. Depending on process parameters $(\mathrm{pH})$, the presence of other substances, and type/structure of pollutants [40], ozone reacts as molecular ozone (direct reactions of ozone) or through the formation of secondary oxidants such as free-radical intermediates (indirect reactions) [32,40,41].

Usually, under acidic conditions $(\mathrm{pH}<4)$, direct electrophilic attack by molecular ozone prevails [28]. With increasing $\mathrm{pH}$, the rate of $\mathrm{HO}^{\bullet}$ radical formation increases. At $\mathrm{pH} \geq 10$, the reaction mechanism changes to an indirect one [42].

The course of ozonation is significantly influenced by water/wastewater composition. Present substances may initiate, promote, or inhibit the radical chain reactions. The initiators include $\mathrm{HO}^{-}, \mathrm{H}_{2} \mathrm{O}_{2} / \mathrm{HO}^{2-}, \mathrm{Fe}^{2+}$, formates, and humic substances. These substances induce the formation of a superoxide radical $\left(\mathrm{O}_{2}{ }^{\bullet}\right)$ from the ozone molecule. Promoters are, for example, $\mathrm{R}_{2}-\mathrm{CH}-\mathrm{OH}$, aryl-R, formates, and humic compounds. Ozone molecules induce the regeneration of superoxide radicals from hydroxyl radicals. The main inhibitors 
of ozonation are $\mathrm{CH}_{3}-\mathrm{COO}^{-}$, alkyl- $\mathrm{R}$, and $\mathrm{HCO}^{3-} / \mathrm{CO}_{3}{ }^{2-}$. These substances are capable of scavenging hydroxyl radicals without subsequent regeneration to superoxide ions. Carbonates and bicarbonates also inhibit ozonation due to a reaction with $\mathrm{HO} \mathrm{O}^{\bullet}$ radicals.

The direct reaction of organics with ozone occurs when the water either contains only a small amount of initiators or contains a large amount of radical scavengers that end the of ozone self-decomposition [27].

Molecular ozone is a rather selective oxidant of organic compounds with a small reaction rate constant [27]. It can react directly with certain functional groups of organic compounds found in water and wastewaters, such as unsaturated and aromatic hydrocarbons substituted with hydroxyl, methyl, and amine groups giving rise, to degradation products. Olefins are more reactive with molecular ozone than aromatic compounds with the same substituent. Because of this high selectivity, many industrial wastewater treatment oxidation processes can be performed using molecular ozone.

Although the ozone self-decomposition rate in aqueous media is dependent on $\mathrm{pH}$ (at high $\mathrm{pH}$, ozone undergoes rapid decomposition), Nakano et al. [43] found that neither the acidic $\mathrm{pH}$ nor the high solubility of ozone affected the degradation/removal efficiency of the studied substances. They studied the process of ozonation of selected hazardous substances in the organic solvents and compared it with the process of ozonation in the aqueous environment in terms of degradation efficiency. It is evident that most of the ozonation studies were performed in an aqueous environment. Concentrations of most target substances are very low and coexist in water with ozone-depleting substances which are present in relatively high concentrations (e.g., $\mathrm{CO}_{2}$, carbonates, bicarbonates), thus reducing ozonation efficiency. Most of the target organic compounds are hydrophobic; hence, they are easy to separate via extraction into an organic solvent directly from water or from activated carbon after adsorption from water. The compounds separated and concentrated in an organic solvent decompose more efficiently via the action of ozone than in water.

Tsai et al. [44] studied the effect of chemical properties of commonly used organic solvents (acetic acid, ethyl acetate, methyl acetate, propionic acid, acetonitrile) on the decomposition rate of non-dissociated and dissociated chlorinated hydrocarbons. Results showed that the decomposition rate for dissociated and non-dissociated substances is different, indicating that the ozonation rate depends on the nature of the organic solvent.

\subsection{Ozonation in Water Treatment}

Ozone is widely used for water treatment, where its disinfecting and oxidizing properties are widely utilized. It improves sensory properties and removes various bacteria and organic and inorganic substances, as well as undesirable color [45]. Figures 2 and 3 were taken during yet unpublished research by the authors as examples of effective decolorization in ozonation experiments with industrial pharmaceutical wastewater. The color of the wastewater (Figure 3) was monitored spectrophotometrically as absorbance (A) at three different wavelengths: 436,525 , and $620 \mathrm{~nm}$. Since the use of conventional disinfectants such as halogens can lead to the production of toxic byproducts, ozone application is, in many cases, a more suitable alternative. The ozonation is usually followed by filtration on granular activated carbon (GAC) or sand filters, which are standard methods of surface water treatment for drinking purposes.

Camel and Bermond [46] summarized the main applications of ozone-based processes in the treatment of surface and ground waters for drinking water preparation. The first step in this process is the removal of organic substances, e.g., humic substances and micropollutants, from raw water to prevent unwanted degradation processes in the distribution of drinking water. These processes could result in bad odors and tastes, and premature ozone consumption could lead to microbial regrowth in distribution systems. Consequently, additional treatment processes such as sand or granular activated carbon filtration are required to meet the drinking water requirements. 


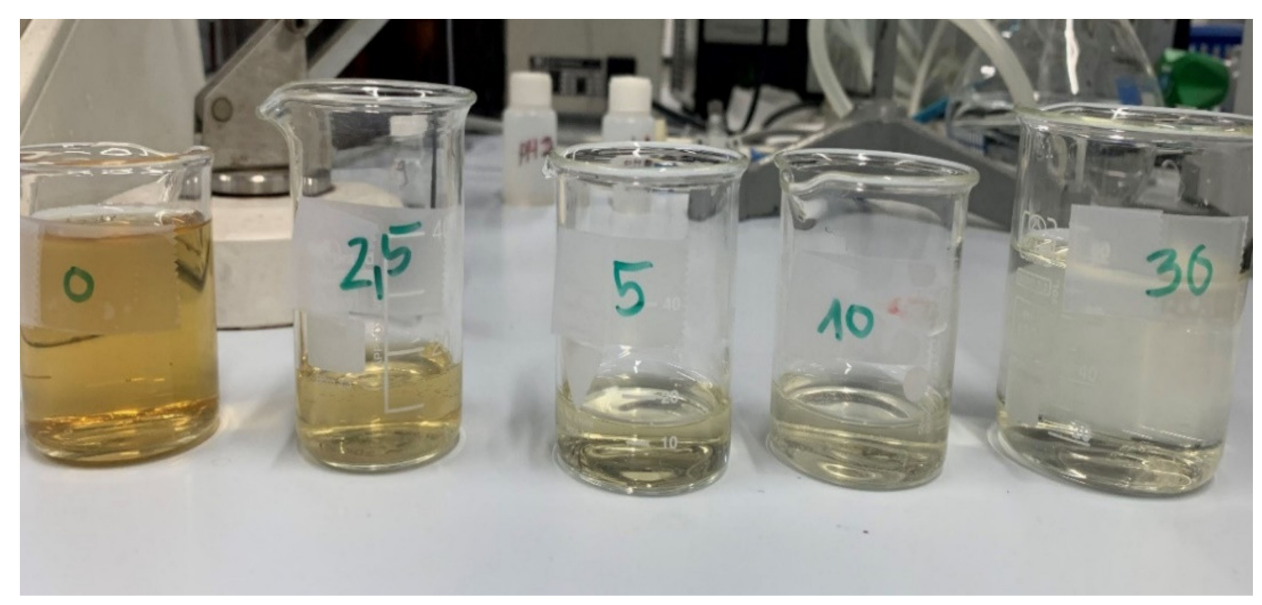

Figure 2. Reduction in color due to the time of ozonation: $0,2.5,5,10$, and $30 \mathrm{~min}$.

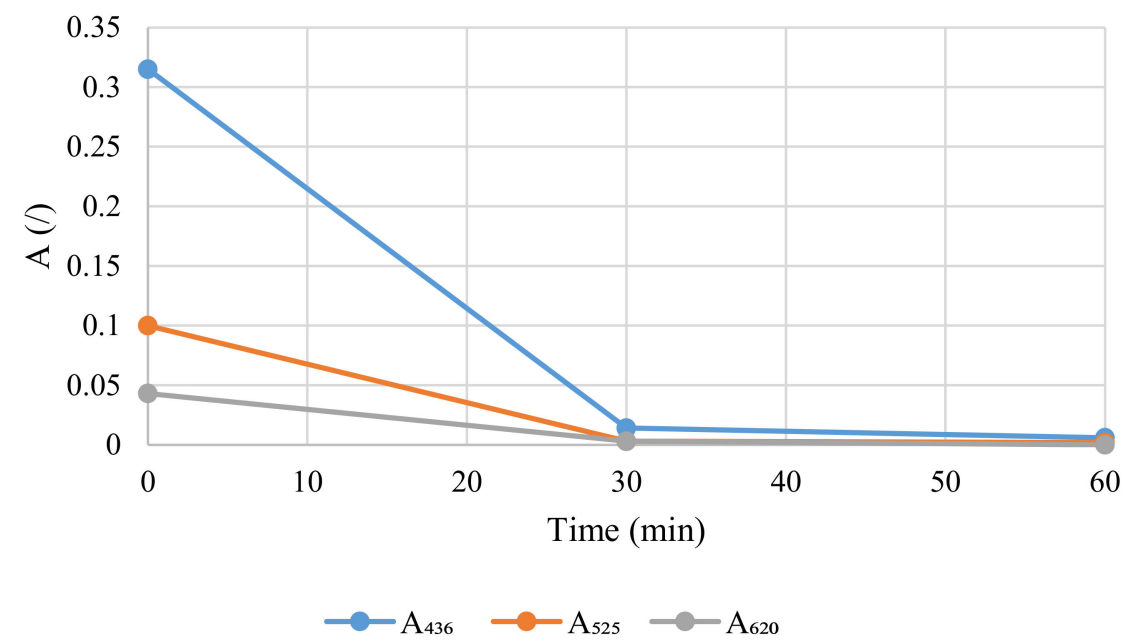

Figure 3. Changes in absorbance (A) vs. the time of ozonation.

Gunten [47] provided an overview of the decomposition of ozone in water and its effects on oxidation processes with ozone and secondary oxidants $\left(\mathrm{HO}^{\bullet}\right.$ radicals) during the ozonation of drinking water. The oxidation kinetics of selected micropollutants and the possibility of using this information to evaluate the fate of these compounds during the ozonation of drinking water was presented. The oxidation of inorganic micropollutants (e.g., $\mathrm{Fe}^{2+}, \mathrm{Mn}^{2+}, \mathrm{H}_{2} \mathrm{~S}, \mathrm{NO}_{2}$ ) by ozone is usually fast and very efficient. The most significant exception is ammonia, which is only slowly oxidized by ozone and $\mathrm{HO}^{\bullet}$ radicals. The oxidation of organic micropollutants can be divided into compounds that can be directly (very effectively) oxidized by ozone and those that do not react with ozone. For ozoneresistant compounds, advanced ozone-based oxidation processes (AOPs, $\mathrm{O}_{3} / \mathrm{H}_{2} \mathrm{O}_{2}$ or $\mathrm{O}_{3} / \mathrm{UV}$ ) can be used for the oxidation. However, in these processes, much of the oxidative capacity is lost due to the matrix. Thus, achieving mineralization of organic compounds is not realistic. Accordingly, thorough analysis of the degradation products must be performed to evaluate the overall gain of the process in terms of degradation of the parent compounds and formation of potentially harmful products.

Audenauert et al. [48] developed a simplified kinetic model describing ozone decomposition, organic carbon removal, disinfection, and bromate formation during ozonation used to treat drinking water. Module calibration and simulation calculations were based on an operational database from a full-scale ozonation system. The results of simulation calculations based on these data showed that this model allows predicting excessive ozone concentration, removal of organic matter, deactivation of bacteria, and bromate formation. Parametric sensitivity analysis revealed a significant influence of kinetic and stoichiometric 
parameters on the output of the model. Some parameters related to bromates and bacteria were shown to be only, but largely, sensitive to their associated concentrations. The oxidation of organic carbon by ozone appears to be advantageous for the application of model control and optimization strategies, as it allows online monitoring of the variables and subsequent acquisition of a large amount of accurate data in real time. This model can also be used as a basis to develop a more detailed model including radical reactions [49] and combined AOPs $\left(\mathrm{O}_{3}, \mathrm{UV}, \mathrm{H}_{2} \mathrm{O}_{2}\right)$ to predict the course and optimize processes.

\subsection{Ozonation in Wastewater Treatment}

Ozone can cause cell lysis and disinfection, a reduction in suspended solids (SS), and an increase in the content of soluble COD [15,35,36]; thus, it can be very efficient in the processes of municipal and industrial wastewater treatment. Ozonation and other ozonation-based processes can be used as a single-step treatment approach, as a pretreatment method followed by other conventional methods, or as a post-treatment step to achieve effluent limits and especially remove MPs that have not yet been addressed in treatment strategies and legislation.

Among the publications focused on the practical use of MP removal technologies, research aimed at extending existing municipal WWTPs using additional tertiary treatment processes dominate [50]. The reason is that municipal WWTPs are the largest point sources of MPs in terms of their distribution to individual compartments of the aquatic ecosystem.

The advantage of chemical oxidation processes, including ozone-based processes, is that they can lead to the complete mineralization of organic substances to carbon dioxide and water or to the transformation of hydrophobic organic compounds into more polar compounds [51-53], thus enhancing biotreatability.

Ozonation represents one of the alternatives for the removal of biologically resistant and toxic compounds from wastewater. It possesses oxidizing properties desirable for its use in wastewater treatment. It is a powerful oxidant capable of oxidative degradation of many organic compounds; it is readily available, is soluble in water, and leaves more biodegradable byproducts. However, total mineralization of organics by ozone is very expensive. Thus, new developed processes apply ozone only for the elimination of toxic compounds and for partial oxidation of resistant organic pollutants from wastewaters, followed by additional biological processes [28].

A major limitation of the implementation of ozonation processes is the economically inconvenient ozone generation coupled with the instability of produced ozone. Due to its instability, ozone must always be generated on site. However, the maximum concentration of the ozone produced from air or oxygen is approximately $4-8 \%$, coupled with the very low (5-10\%) energetic efficiency of the production and the requirement of a dry input of air or oxygen. Process efficiency is highly dependent on the efficient gas-liquid mass transfer, which is quite difficult to achieve due to the relatively low solubility of ozone in aqueous solutions. Schematics of typical equipment used for ozonation and typical operating parameters were presented by Gogate and Pandit [54].

Schaar et al. [55] and Ibáňez et al. [56] considered the ozonation of wastewater at the outlet of a WWTP to be a promising technology for reducing MP emissions. Eggen et al. [24] also confirmed the ozonation of wastewater at the outlet of a WWTP to be a promising option since it presented a significant reduction in toxicity and MP emissions in discharged WW of real WWTPs. Ozonation of excess sludge also caused increased removal of endocrine-disrupting compounds absorbed into the sludge. Qiang et al. [38] presented the results of research of the suitability of the use of ozone for the degradation of endocrine disruptors present in activated sludge and initiated further research work aimed at removing other compounds adsorbed on sludge. Gradclément et al. [57] considered the ozonation of wastewater at the outlet of a WWTP to be a promising enhancement of biological processes to remove MP, where it can also be combined with other physical-chemical or chemical processes. 
The main disadvantage of ozonation is the insufficient mineralization of pollutants and the formation of transformation products. However, ozone promotes the partial oxidation of pollutants [58]. Thus, newly developed processes apply ozone only for the elimination of hazardous compounds and/or for partial oxidation of resistant wastewater organic pollutants to improve their characteristics.

\subsubsection{Enhancement of Biodegradability}

Ozone mainly promotes the partial oxidation of pollutants, but its action depends upon many parameters. In addition to direct reaction (ozonolysis), it can also react via radical mechanisms such as other AOPs. The combination of ozonation with homogeneous or heterogeneous catalysis which can increase the production of hydroxyl radicals represents a potential solution when the enhancement of biodegradability is considered. Natural organic compounds and/or carbonates in soil and/or underground water can also act as catalysts depending on their concentration and $\mathrm{pH}$.

Controlled ozonation processes which can inactivate inhibitory compounds in wastewater treatment and improve the bioavailability of recalcitrant organic molecules by fragmentation are applied. Thus, cheaper methods for removing resistant and toxic substances include a combination of partial ozone oxidation and subsequent mineralization by biological processes [59-64]. Partial/controlled oxidation changes the structure and chemical properties of organic substances by breaking them down into smaller fragments. Oxygen is incorporated into the reaction products to form alcohols, carboxylic acids, and other oxygenates. Compounds with a specific functional group, such as aromatic rings and $\mathrm{C}=\mathrm{C}$ bonds, are prone to react with ozone to form carbonyl compounds and, in the case of aromatic hydrocarbons, to form aliphatic acids [65]. Ozone oxidation products are, in many cases, more readily biodegradable than products produced by other oxidizing agents [66]. At the same time, the biodegradability of the contained organic substances is improved (increase in the value of the $\mathrm{BOD}_{5} / \mathrm{COD}$ ratio). In addition to improved biodegradability, oxidation by ozone may also contribute to a reduction in the potential toxicity of these waters $[59,62]$. This allows the subsequent use of biological processes to remove remained pollutants (e.g., nitrification process). Ozonation is also one of the most frequently investigated and applied methods of post-treatment of seepage water after biological treatment [67].

The changes in municipal landfill leachate biodegradability were also studied by Derco et al. [68]. The maximum observed $\mathrm{BOD}_{5}$ value, measured in ozonated biologically pretreated landfill leachate using a respirometric method, was $244 \mathrm{mg} \cdot \mathrm{L}^{-1}$. Biodegradability expressed as $\mathrm{BOD}_{5} / \mathrm{COD}$ ratio increased from zero up to a maximum value of 0.21 , corresponding to an ozone consumption of $0.7 \mathrm{mg}$ per $\mathrm{mg}$ of COD reduced.

\subsubsection{Reduction in Toxicity}

The main purpose of chemical pretreatment is the partial oxidation/fragmentation of bioresistant compounds to produce biodegradable intermediates. The mineralization degree should be minimal during pretreatment to avoid unnecessary expenditures on chemicals and energy, thus reducing operating costs. This is important because electricity costs account for about $60 \%$ of the total operating costs. Organics that are highly or completely resistant to conventional biological treatment can be totally mineralized using a combined chemical-biological system. However, during ozonation, formation of toxic metabolites has already been noted by several authors, and, despite the good removal rates of contaminants, which was confirmed sometimes even with efficient mineralization, the toxicity increased. Hence, it is necessary to upgrade physical-chemical monitoring of any treatment efficiency with biological tests to detect such changes and to avoid significant environmental impact.

In the study of Peolmas et al. [69], pre- and post-ozonation of wastewater from truck cleaning was investigated. Laboratory experiments with biological treatment were accomplished with activated sludge in sequencing batch reactors. Two strategies were 
applied: (i) influent pretreatment with ozone followed by activated sludge treatment, and (ii) activated sludge treatment followed by polishing with ozone. An $80 \%$ decrease in ecotoxicity was observed for algal growth inhibition and a $10 \%$ decrease was seen for Daphnia immobilization for ozone post-treated influent in comparison to the pretreated one. Prolonged $(7 \mathrm{~h})$ effluent ozone polishing tests were conducted at two $\mathrm{pH}$ set points to assess the impact of radical formation during ozone treatment. The authors concluded that ozone as a pretreatment step had no significant influence on ecotoxicity and COD removal, whereas effluent polishing could reduce ecotoxicity and improve environmental effluent characteristics.

The study of Park et al. [70] compared chlorination and ozonation in terms of the ecotoxicity of byproducts when wastewater is disinfected. It was confirmed that the concentration of three halomethanes increased with longer contact time $(24 \mathrm{~h})$, while the concentration of halo-acetic acids (HAAs) was not affected by longer contact time regardless of the process applied. Ecotoxicity was determined using Daphnia magna and correlated to the formed formaldehyde concentrations. The authors concluded that both the disinfection efficiency and the byproduct formation potential should be considered to avoid harmful impacts on aquatic environments when a disinfection method is used for the final treatment of the wastewaters.

Wu et al. [71] studied the ozonation of wastewater in the presence of bromide where bromate is the expected byproduct. The cytotoxicity, genotoxicity, and DNA/RNA oxidative damage to Chinese hamster ovary cells of organic extracts from ozonated wastewater in the absence or presence of bromide were studied. Detoxification was effective in the case of ozonation without bromide, while the cytotoxicity and genotoxicity of effluents spiked with bromide significantly increased. When the bromide concentration in the effluent was $2000 \mu \mathrm{g} \cdot \mathrm{L}^{-1}$, ozonation resulted in 1.4-1.5 times the cytotoxicity and 1.5-5.0 times the genotoxicity of the non-ozonated secondary effluent. Both parameters were correlated with an increase in the formation of total organic bromine (TOBr). It was concluded that, during the ozonation of wastewaters containing bromide, particular attention should be paid to the organic byproducts such as TOBr.

Kharel et al. [72] explored the ozone dose dependency of the formation and successive removal of ozonation products in a pilot- and full-scale ozonation system after activated sludge treatment. The concentrations of several $\mathrm{N}$-oxides (erythromycin $\mathrm{N}$-oxide, venlafaxine $\mathrm{N}$-oxide, and tramadol N-oxide) increased up to an ozone dose of $0.56-0.61 \mathrm{mg}_{\text {ozone }} \cdot \mathrm{mg}_{\mathrm{DOC}}{ }^{-1}$ while they decreased at elevated doses of $0.7-1.0 \mathrm{mg}_{\text {ozone }} \cdot \mathrm{mg}_{\mathrm{DOC}}{ }^{-1}$. The same outcome was confirmed in the case of determined transformation products (diclofenac 2,5-quinone imine, 1-(2,6-dichlorophenyl)indolin-2,3-dione, 1-(2-benzoic acid)-(1H,3H)-quinazoline2,4-dione). The formation maximum of a given compound occurred at a specific ozone dose characteristic for each compound, but it was not affected by the composition of the wastewater used in the experiments.

\subsubsection{Municipal Wastewater}

The main goal of wastewater treatment plants (WWTPs) is to remove organic pollution and nutrients to meet specific discharge requirements. However, in recent years, attention has shifted to micropollutants (MPs), because even low concentrations of MPs can have an adverse effect on the environment. Ozone-based processes appear to be promising technologies for the removal of these substances as part of tertiary wastewater treatment. Published results have shown that municipal wastewater treatment plants are also the most important point source of priority substances and micropollutants into the environment because of the low removal efficiencies of many of these compounds [24,38,73]. Currently, only half of the micropollutants are eliminated in conventional WWTPs, mainly by degradation and sorption onto sludge. There are also many compounds with hydrophilic characteristics that do not adsorb onto the sludge and are persistent or transformed into mostly unknown products. To reduce the negative environmental impact and to improve the quality of the discharged wastewater, appropriate measures should be introduced [24]. 
Among the publications focused on practical applications of MP removal technologies, work aimed at extending existing municipal WWTPs to other tertiary processes dominates [50]. The reason for this solution is that municipal WWTPs are collecting these compounds in a certain area via wastewaters and, in the case of their poor removal, represent the largest point sources of MPs in individual components in the aquatic ecosystem; however, they can serve as primary barriers against the spread of MPs.

Deblonde et al. [74] monitored data on the concentrations and removal efficiencies of 50 pharmaceutical compounds, six phthalates, and bisphenol A at inflows and outflows in WWTPs. The phthalate removal efficiency was above $90 \%$ for most of the compounds studied. The rate of antibiotic removal was about $50 \%$, and that for bisphenol A was $71 \%$. Analgesics, anti-inflammatory drugs, and beta-blockers were found to be the most resistant (30-40\% removal efficiency).

Hollender et al. [20,75] studied the removal efficiencies of 220 micropollutants in a real WWTP, which was extended to tertiary ozonation, followed by a sand biofilter. During ozonation, compounds with an aromatic nucleus, amino groups, and double bonds, e.g., were eliminated at an ozone dose of $0.47 \mathrm{~g}$ ozone $\cdot \mathrm{g}^{-1} \mathrm{DOC}$ (sulfamethoxazole, diclofenac, carbamazepine). More resistant compounds, such as atenolol and benzotriazole, were removed more efficiently only at higher doses of ozone $\left(0.6 \mathrm{~g}_{\mathrm{ozone}} \cdot \mathrm{g}^{-1} \mathrm{DOC}\right)$. Only a few micropollutants (e.g., triazine herbicides) passed the treatment unchanged on a larger scale. The energy consumption for tertiary ozonation was around $0.035 \mathrm{kWh} \cdot \mathrm{m}^{-3}$, which corresponds to $12 \%$ of the energy consumption in a typical medium WWTP with nutrient removal [20].

The Neugut WWTP $(1,050,000$ PE) was the first in Switzerland to introduce long-term ozonation aimed at the removal of MPs. A specific ozone dose of $0.55 \mathrm{~g}_{\text {ozone }} \cdot \mathrm{g}^{-1}$ DOC was determined to ensure an average reduction in the concentration of 12 selected indicator substances by $80 \%$. Subsequent monitoring of 550 substances confirmed the high efficacy of this dose. After ozonation, additional biological treatment is required to eliminate the possible ecotoxic effects caused by biodegradable transformation products and oxidation byproducts [13].

\subsubsection{Integrated Processes}

Because conventional activated sludge-based processes are often insufficient to remove most organic micropollutants (MP), various alternative technologies can be implemented to remove them, such as integrated processes that combine two or more different methods [57]. An additional problem is related to the substances adsorbed on activated sludge which can affect the efficiency of its management and ways of final disposal because they can be released into the environment during its application in agriculture. The conclusions of the Ninth Implementation Report and the programs for the implementation of Council Directive 91/271/EEC on the treatment of municipal wastewater (COM, 2017) show that $58 \%$ of sewage sludge is reused, mostly in agriculture. Handling of this sludge can cause the release of hazardous, harmful, and toxic substances into soil and groundwater [76]. In fact, the application of stabilized sludge into soil remains the final solution in many countries even with a longer perspective [77].

Another way of their entry in the environment is the stripping of volatile components (reaction intermediates and products) during conventional wastewater treatment, followed by their wide-range mobility.

In addition, the treatment of excess sludge produced significantly increases the cost (approximately $25-60 \%$ of the total cost) of wastewater treatment [38,78-81]. Recently, the research and the development of new methods and strategies for the utilization, minimization, and disposal of excess sludge have been in focus. Ozone treatment is one of the studied and partially applied processes for excess sludge control. During ozonation of the sludge, cell membranes are disrupted, and the intracellular material is released into the liquid phase [82]. This enhances the first step of the process hydrolysis. As a result, toxicity is reduced and biogas production potential is increased as it has been proven in the 
study [83]. In the Figure 4 unpublished data on biogas production based on the methodology used in in the study of Boševski et al. [83] are presented. It can be clearly seen that contamination of the sludge with toxic compounds decreased biogas gain while ozonation led to increased hydrolysis of treated sludge resulting in better biogas production. At the same time also degrade pollutants and prevent their release into the environment. Ozonation of sludge is presented as the most cost-effective technology with regard to the disintegration performance $[84,85]$. One of the possible uses of ozonated sludge is in biological nitrogen removal, where it can perform as an external carbon source, thereby extensively reducing the operational cost of this process [35]. Thus, one of the investigated and to some extent applied processes of reducing the production of excess activated sludge is the use of ozone.

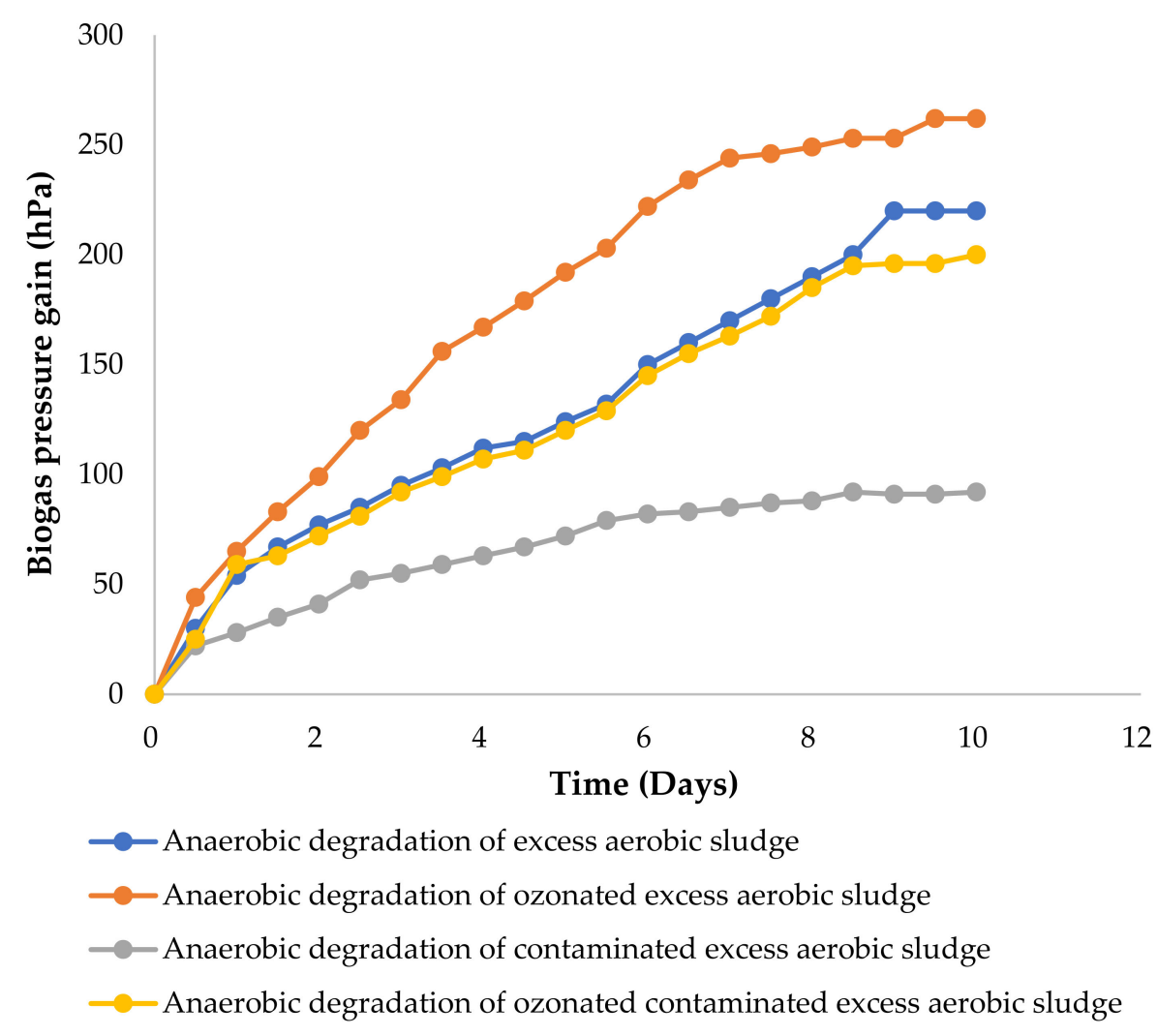

Figure 4. Biogas production in a system with aerobic sludge, ozonated aerobic sludge, aerobic sludge contaminated with model antibiotic, and ozonated contaminated aerobic sludge: Illustration of the concept.

Moreover, excess sludge generated during wastewater treatment affects the wastewater treatment economy, increasing the total cost by $25-60 \%$ [34,78-81]. This is one of the reasons why new, alternative plans for sludge management have been initiated.

The possibilities of reducing the production of excess sludge have been intensively investigated, resulting in several publications. State-of-the-art sludge reduction technologies applied in both wastewater and sludge treatment lines were presented by Wang et al. [86]. According to these authors, in the future, effort should be placed toward sludge reduction technologies for the removal of organic micropollutants and heavy metals.

Kosowski et al. [87] investigated the effect of ozone on the physicochemical and microbiological parameters of sludge. The experiments were performed in a counter current reactor, which ensures optimal mass transfer and contact time of ozone with insoluble substances (flocs of activated sludge). A reduction in the number of colonyforming units (CFU) was achieved. Sludge dewatering improved. The COD and $\mathrm{BOD}_{5}$ values increased with the process time, while the total content of insoluble particles in the sludge did not change. 
The same was also noted in the study of Marce et al. [88], who studied ozonation as a treatment of activated sludge supernatant liquid from a coastal WWTP containing various micropollutants, mainly pharmaceuticals. The aim of their study was to correlate the dependency of applied ozone dosage on the effectiveness of micropollutant removal, as well as activated sludge characteristics. The authors observed that, even with low transferred ozone doses, removal efficiencies of the studied micropollutants reached up to $99 \%$. Furthermore, the applied ozone dosage had positive effect on activated sludge, increasing COD solubilization, as well sludge volume index. Many studies dealing with excess sludge treatment considered ozonation as one of the easiest and fastest modern technologies for micropollutant removal, excess sludge reduction, and prevention of subsequent release of these compounds into the environment $[12,38,76,79,89]$.

Another focus of research in this area is related to the possibilities of using ozone for an on-step integrated process of decomposition of MPs after their adsorption on activated sludge and simultaneous disintegration of cells of excess sludge microorganisms to reduce their quantity. A positive impact of the accumulation and biosorption of hydrophobic organic substances to activated sludge is that it results in their elimination from wastewater. However, the contaminated sludge presents a new challenge, especially if the contamination is reversibly bound. A novel trend in excess sludge management is the combination of biological and chemical processes, which leads to a reduction in excess sludge production, while also providing the transformation/degradation of pollution sorbed onto this sludge [88].

During laboratory research focused on the utilization of ozone for the degradation 2-mercaptobenzothiazole (2-MBT) in an integrated process after its adsorption on activated sludge and simultaneous disintegration of the excess sludge to reduce its production, a $99 \%$ efficiency of its removal from excess activated sludge was observed after $20 \mathrm{~min}$ of ozonation [90].

Despite approximately the same 2-MBT removal efficiencies at different reaction time values (20 and $60 \mathrm{~min}$ ), the effect of the samples on the respiratory activity of activated sludge was significantly different. With an increase in the time of ozonation, lower inhibitory effects of the ozonized sample of the mixture of activated sludge and 2-MBT on the respiratory activity of non-ozonized/reference activated sludge microorganisms, greater tolerance of these MOs to higher substrate concentrations (ozonized mixture of activated sludge and 2-MBT), and greater values of specific respiratory rate with this ozonized substrate were observed [91].

\subsubsection{Combined Processes}

Ozonation can be combined with a variety of different processes, e.g., energy enhancement using light (UV photochemical methods), addition of $\mathrm{H}_{2} \mathrm{O}_{2}, \mathrm{Fe}^{2+} / \mathrm{H}_{2} \mathrm{O}_{2}$ (photoFenton processes), and addition of other catalysts $\left(\mathrm{Fe}^{3+}, \mathrm{Fe}^{0}, \mathrm{TiO}_{2}\right.$, etc.). There are also several nonphotochemical methods available. Combined chemical and biological oxidation processes have a well-known potential for removing recalcitrant and anthropogenic substances from wastewater. It should be noted that AOPs can sometimes produce byproducts, which may inhibit the biological processes when integrating the ozonation process into biological treatment systems [90].

A combined ozonation and bentonite coagulation process was investigated as a method of concurrently removing humic acid and $o$-dichlorobenzene from drinking water. Bentonite improved the coagulation process, resulting in an enhancement in the removal efficiency of humic acid [92].

Laboratory tests have shown that ozone can be successfully used to remove micropollutants from sewage [20]. The wastewater treatment plant in Regensdorfe, Switzerland is a successful example of such a system. It has been shown that ozonation is an effective way of removing a wide range of organic micropollutants from sewage. More than $90 \%$ of substances were transformed at relatively low ozone doses of about 0.6 to $0.8 \mathrm{~g}_{\mathrm{ozone}} \cdot \mathrm{g}_{\mathrm{DOC}}{ }^{-1}$. Antibiotics, hormones, analgesics, etc. were almost completely removed. It was confirmed 
that, after ozonation, a further step is required, sandblast sand filtration to remove reactive oxidation products. Another advantage of this process is that, in addition to removing micropollutants, ozone removes not only bacteria but also scent, color, and foam. A $10-20 \%$ cost increase was associated with ozonation in the WWTP process line compared to the operation costs required for the original technology.

Chys et al. [93] investigated the combination of three different filtration methods and ozonation as an enhanced tertiary treatment of municipal wastewater after biological treatment. Filtration methods, such as trickling filtration (TF) and slow sand filtration (SSF), proved to be ineffective for the removal of MP present in the wastewater. A third applied filtration method - filtration by activated biocarbon (BAC) — expressed $99 \%$ removal efficiency; however, operational costs were too high for successful full-scale implementation. The ozonation process removed $90 \%$ of MP from wastewater but resulted in increased nonselective toxicity of the effluent. The best technique for MP removal and the prevention of toxicity of secondary effluent was SSF followed by the ozonation process. To maintain the process control, the authors provided innovative mathematical correlation models for the monitoring and control of micropollutant removal when applying the enhanced tertiary treatment.

A significant increase in genotoxicity was observed during ozone applications explained as a consequence of the formation of various hazardous transformation products [89]. However, this effect could be efficiently eliminated using a sequential sand filter $[20,52,94,95]$. Results indicated a greater decrease in toxicity of landfill leachate by ozone compared to the Fenton reaction. The experimental results presented by Wang et al. [96], Hollender and Escher [75], and Hollender et al. [20] support the expectation that a combined process of ozone/biofiltration may enhance the overall treatment efficiency of secondary effluent treatment.

The production of excess sludge in biological treatment processes cannot be avoided. The application of stabilized sludge to the soil remains the ultimate solution in many countries, even in the longer term [77]. However, its application can cause the release of hazardous, harmful, and toxic substances into soil and groundwater [76]. In addition, substances adsorbed on activated sludge can be released into the environment in the form of volatile components, as well as reaction intermediates and products. An overview of state-of-the-art sludge reduction technologies used in wastewater treatment technology lines was provided by Wang et al. [86]. Prospectively, these technologies should also focus on the removal of organic micropollutants.

The work of Bernal-Martínez et al. [97] is the first on ozone utilization to remove toxic and carcinogenic substances from waste biological sludge. The results showed that, through ozonation of the anaerobically stabilized sludge and its recirculation into the stabilization reactor, an increase in the removal of polycyclic aromatic hydrocarbons (PAH) by $11 \%$ was achieved. In combination with hydrogen peroxide, the efficiency of PAH removal increased by $31 \%$.

The results of Vranitzky and Lahnsteiner [98] also confirmed that the ozonation of anaerobically stabilized sludge and its recirculation into the stabilization reactor, in addition to the increasing the reduction in organic solids, increased biogas production and reduced the content of micropollutants, such as nonylphenol ethoxylates (NPEOs) and PAHs. This could enable safe reuse of stabilized sludge in agriculture and landscaping applications. The same trend was also observed in the study of Ak et al. [99]. They showed that the anaerobic stabilization of excess activated sludge after ozonation virtually doubles the volume of biogas produced compared to the usual stabilization process. The ozonation of excess sludge also caused the increased removal of endocrine-disrupting compounds absorbed onto sludge.

Qiang et al. [38] confirmed that ozone treatment is suitable for the degradation of EDCs present in the activated sludge, and further research work focused on the removal of other compounds adsorbed onto sludge was initiated. 
Nie et al. [100] used two continuously activated sludge laboratory treatment plants. One was operated in conjunction with excess sludge ozonation, while the other was operated as a control system. The results show that ozone led to a zero production of excess sludge in the system. Although ozonation caused a relatively lower specific rate of oxygen consumption by activated sludge microorganisms, it had little effect on the performance of the system in terms of COD and nitrous substance removal. The sludge reduction system with ozonation was more favorable than the control system for the removal of target EDCs, and, at the same time, it eliminated the risk of surplus sludge with residual EDC content.

\subsection{Ozonation of Micropollutants}

Conventional mechanical-biological wastewater treatment plants are unable to completely remove most MPs; therefore, they pass to various compartments of the ecosystems where their impact can be significant and long-term even at relatively very low concentrations [101].

Ozonation causes a reduction in the concentration of many trace organic compounds from effluent wastewater $[20,102-106]$ via direct and indirect oxidation reactions.

An emerging task for municipal wastewater treatment plants (WWTPs) is to act as a barrier for micropollutants and prevent the emission of potentially harmful substances into the aqueous environment. However, the occurrence of new still "uncontrolled" micropollutants, such as endocrine disruptors, pharmaceuticals, and personal care products, require the use of advanced wastewater treatment processes, especially in cases where a surface water is used to produce drinking water. Since biological wastewater treatment processes cannot effectively remove toxic and biologically resistant pollutants, this necessitates the development of new wastewater treatment processes [52,107,108].

Luo et al. [12] summarized the occurrence of MPs in the aquatic environment. The removal efficiency of selected MPs from WWTPs in 14 countries/regions ranged from $12.5 \%$ to $100 \%$. Biological treatment can efficiently remove polar persistent micropollutants. The efficiency of these processes can be increased by changing technological and operational parameters (sludge age, hydraulic residence time, temperature, and redox conditions) or it can be enhanced by a combination with other different treatment technologies, i.e., hybrid system. Although advanced processes such as activated carbon adsorption, AOPs, nanofiltration, reverse osmosis, and membrane bioreactors can achieve higher and more consistent MP removal, they usually result in high operational costs, and some of them generate byproducts and concentrated waste streams.

Eggen et al. [24] presented a national strategy for the elimination of MPs in wastewater treatment following the results of full-scale case studies using ozonation or powderactivated carbon treatment, as well as an amendment to the Water Protection Act in March 2014, in which the Swiss government decided to introduce technical measures at selected municipal WWTPs to reduce the burden of MPs and toxicity in discharged wastewater. The costs of wastewater treatment depend on the state of the reconstructed WWTP and technology. It is expected that, in Switzerland, after modernization, the average cost of wastewater treatment, including the removal of macronutrients, is expected to increase by $10-20 \%$ compared to the initial cost of WWTPs with a capacity of $>80,000$ population equivalent (PE) and 20-50\% for WWTPs with a load of 8000 to $80,000 \mathrm{PE}$, depending on the specific conditions and the chosen technology. WWTPs with a capacity of $<8000 \mathrm{PE}$ will be reconstructed and modernized only exceptionally. The annual cost of sewerage and wastewater treatment in Switzerland is expected to increase by 6\%. The modernization of cleaning processes will cause increased energy consumption between $5 \%$ and $30 \%$. The total national electricity consumption is expected to increase by $0.1 \%$. This increase in energy consumption will be offset by the increased energy efficiency of treatment and the production of renewable energy (biogas and solar energy) at the WWTPs.

The evaluation of applied advanced oxidation methods for the removal of priority substances [7], as defined in the EU Directive [6], showed that ozone alone promotes the partial oxidation of pollutants and increases their biodegradability, but their complete 
mineralization is usually not achieved. This deficiency can be solved by a combination of homogeneous and heterogeneous catalysts (catalyzed/adsorption ozonation) or the addition of $\mathrm{H}_{2} \mathrm{O}_{2}$ or other AOPs (e.g., photocatalysis). Another way to reduce operating costs when applying ozone-based procedures is its use in several nodes of the WWTP technological line, i.e., increasing the efficiency of the use of supplied ozone.

Rodríguez et al. [109] provided the environmental optimization of ozonation for urban wastewater spiked with micropollutants such as diuron, ibuprofen, diclofenac, sulfamethoxazole, erythromycin, bezafibrate, gemfibrozil, atenolol, carbamazepine, hydrochlorothiazide, caffeine, and dipyrone metabolite $N$-acetyl-4-amino-antipiryne. Optimal reaction conditions were determined, and removal efficiencies above $80 \%$ were achieved. However, the authors suggested that the efficient use of ozone was not in correlation with pollutant removal. They assessed the environmental impact of the optimized ozonation process as a function of potential toxicity reduction and toxicity reduction per unit of mass of greenhouse gas emissions. Results showed that maximizing toxicity removal led to higher greenhouse gas emissions, suggesting an environmental tradeoff between effectiveness and environmental consideration.

Suarez et al. [110] investigated the removal of antimicrobial agent triclosan by an ozonation process with the aim of determining reaction kinetics, possible reaction pathways, and changes in microbial activity of the investigated compound. The authors determined that the triclosan reaction with aqueous ozone follows a second-order reaction rate whereby the ozone initially attacks the phenol moiety of triclosan. A microbial assay of the treated sample indicated that direct ozonation successfully eliminated triclosan's antimicrobial activity. Indirect ozone reactions via the formation of radical intermediates were also investigated. However, the authors declared that triclosan removal occurred mainly due to direct ozonation, as indirect ozonation accounted only for 35\% of the observed removal. Results of this study suggested that direct ozonation is sufficient for both actual removal of triclosan and elimination of its microbial activity.

Chys et al. [111] developed and applied robust correlation models for ozone-based removal of micropollutants (MPs) for full-scale municipal WWTPs. Application of these models on a pilot scale offers predictions of MP removal solely using a second-order reaction rate constant with ozone. The model is based on $\mathrm{UVA}_{254}$ and fluorescence monitoring of MP abatement.

Lee and Gunten [37] compared the oxidative transformation of MPs present in municipal WWTP influent by means of selective and nonselective oxidants. All studied micropollutants contain electron-rich moieties (ERM), and wastewater also contains varying organic compounds common in municipal wastewaters which compete for oxidants. According to the second-order rate constants, the authors indicated that nonselective oxidants (hydroxyl radicals) show nearly diffusion-controlled reactivity with all organic moieties present in the wastewater sample. Selective oxidants, such as chlorine, chlorine dioxide, ozone, and ferrate(VI), react only with substances with ERM; therefore, the same dose of selective and nonselective oxidant led to higher MP removal efficiency in the case of the former.

Schaar et al. [55] investigated the ozonation process as tertiary municipal wastewater treatment for the removal of various micropollutants (MPs). MPs present in wastewater were bisphenol A, 17-ethinylestradiol, and various pharmaceuticals. Conventional wastewater treatment upgraded to best available technology (BAT) standard was efficient in the removal of most MPs. However, substances such as carbamazepine and diclofenac were not degraded and required further treatment. The ozonation process proved to be an effective method for the removal of bioresistant and recalcitrant MPs present in WWTP effluent.

Chys et al. [112] analyzed the variability of WWTP effluents and trace MP quantity and quality for the effective implementation of ozonation treatment. Variability in effluent quality and quantity was determined in 15 Belgian WWTPs. The authors declared that accurate information about pollution resulted in optimized tertiary ozone treatment in terms of ozone dosage, instantaneous ozone demand, etc. Results also suggested that, 
in addition to the characterization of organic effluent load, further parameters such as alkalinity and $\mathrm{pH}$ are necessary for the optimization of ozone treatment and differential dosing strategy.

Rivas et al. [113] investigated various tertiary ozone-based treatments of secondary WWTP effluent to further reduce COD and improve mineralization. The application of ozonation treatment resulted in the removal of 50\% COD and improved mineralization by $40 \%$. The combined process of $\mathrm{O}_{3} / \mathrm{H}_{2} \mathrm{O}_{2}$ enhanced the COD removal only slightly but led to an increase in mineralization by $70 \%$. Furthermore, a combination of ozone treatment with activated carbon and a $\mathrm{O}_{3} / \mathrm{UV}$ process was investigated, but it did not improve the ozonation efficiency. The authors concluded that applied systems were successful in the further removal of COD and mineralization enhancement, and they can be easily modeled by empirical mathematical equations.

Degradation of seven endocrine disruptors (nonylphenol, bisphenol A, bis(2-ethylhexyl) phthalate, dimethyl phthalate, dibutyl phthalate, diethyl phthalate, and benzyl butyl phthalate) was investigated in work of Balbanič et al. [114]. Two pilot-plant scale systems ((i) anaerobic biological treatment followed by aerobic biological treatment, ultrafiltration, and reverse osmosis; (ii) anaerobic biological treatment followed by membrane bioreactor and reverse osmosis) and four laboratory-scale AOPs (ozonation, photocatalysis with $\mathrm{TiO}_{2}$, Fenton, and photo-Fenton reaction) were applied. Results indicate that both pilot plants and the photo-Fenton reaction were successful in EDC removal (98-100\%), while the remaining processes were less effective $(70-90 \%)$.

In the work of Zimmermann et al. [115], secondary WWTP effluent was treated in a full-scale ozonation reactor with the aim of disinfecting and further oxidizing treated wastewater. Oxidation kinetics, ozone utilization, disinfection efficiency, and byproduct formation were investigated for seven different ozone doses ranging from 0.21 to $1.24 \mathrm{~g}_{\text {ozone }} \cdot \mathrm{g}^{-1}$ DOC. Substances with high ozone reactivity (carbamazepine, diclofenac) were eliminated completely within the gas bubble column, while substances with lower ozone reactivity were eliminated only at higher ozone doses. Oxidation efficiency was predicted by Monte Carlo simulations and proved to be 2.5 -fold higher than full-scale ozonation results. Secondary effluent treatment by ozonation resulted in the formation of bromate (potential human carcinogen) and $N$-nitrosodimethylamine (NDMA). Disinfection by ozonation treatment also resulted in a reduction in bacteria in terms of total cell count (TCC) and inactivation of E. coli.

Zucker et al. [116] used the Quench Flow Module (QFM) for the prediction of ozone performance in ozonation processes of a water matrix. QFM is a bench-scale experimental technique for measurement of the first 5-500 ms of ozone depletion in a system to accurately determine the ozone exposure in water ozonation reactions. Although the QFM was introduced as an efficient complete stirring tank reactor, ozone exposure ranged over three orders of magnitude when different selected test compounds with moderate reactivity toward ozone were used in the calculations. Effects were far beyond uncertainty ranges for the apparent second-rate kinetic constants and were observed with different ozone-injection techniques (QFM, bubble columns, batch experiments, and Venturi injection). These data suggested that previously proposed mixing effects were not responsible for the difference, and other still unobtained data might be relevant. Results also suggested that ozone exposure calculations from the relative residual concentrations of test compounds are not an effective option for the evaluation of ozone-based processes of secondary WWTP effluents.

In the work of Marce et al. [88], the role of ozonation as pretreatment or post-treatment of wastewater from a biological step in WWTP was discussed. The authors suggested that most applications of ozonation on WWTP occur in a post-treatment step. However, their work focused on the utilization of ozone in pretreatment. The results of their study were supported by aggregate parameters of chemical oxygen demand, biological oxygen demand, turbidity, and $\mathrm{UV}_{254}$ absorbance. Kinetics and ozone transfer parameters were also investigated. 


\section{Ozone-Based Advanced Oxidation Processes}

In general, AOPs are defined as oxidation processes, which can generate hydroxyl radicals in sufficient quantity to affect organic pollution [117]. Processes could involve energy enhancement in terms of light involvement (UV photochemical methods) in combination with ozone, $\mathrm{H}_{2} \mathrm{O}_{2}$, ozone $/ \mathrm{H}_{2} \mathrm{O}_{2}, \mathrm{Fe}^{2+} / \mathrm{H}_{2} \mathrm{O}_{2}$ (photo-Fenton process), and $\mathrm{TiO}_{2}$ [117]. There are also several nonphotochemical methods available $\left(\mathrm{Fe}^{2+} / \mathrm{H}_{2} \mathrm{O}_{2}\right.$ (Fenton process), ozonation, combination of ozone and $\mathrm{H}_{2} \mathrm{O}_{2}$, ozone with different catalysts, etc.). The state of the art of AOPs for wastewater treatment was presented in detail by Poyatos et al. [29]. Ribeiro et al. [7] summarized the data published in the last decade on the application of advanced oxidation processes (AOPs) for the removal of priority substances and some other pollutants defined in the Directive 2013/39/EU. The AOPs are accepted processes of degradation of resistant substances or at least their transformation into biodegradable substances. Processes based on the Fenton reaction are most common in priority compound removal from water. Heterogeneous photocatalysis is the second most common method of polluting substances removal defined in the Directive 2013/39/EU.

There are many ways to use ozone in combination with other techniques, such as ultrasonic/UV radiation or other hybrid methods [54,118,119].

The course of ozonation is significantly influenced by wastewater composition as mentioned in Section 2.1.

Mujtaba et al. [30] reviewed ozone-based processes $\left(\mathrm{O}_{3}, \mathrm{O}_{3} / \mathrm{H}_{2} \mathrm{O}_{2}, \mathrm{O}_{3} / \mathrm{UV}, \mathrm{O}_{3} / \mathrm{GAC}\right.$, $\mathrm{O}_{3} / \mathrm{US}, \mathrm{O}_{3} / \mathrm{UV} / \mathrm{H}_{2} \mathrm{O}_{2}$ ). These processes have proven to be very effective, particularly in removing and increasing the biodegradability of the various resistant substances present in wastewater. They are characterized by high oxidizing power and excellent disinfection properties, making them an attractive choice for the elimination of a wide range of contaminants. The paper presented an overview of mechanisms and applications of various ozone-based AOPs in the treatment of municipal/industrial wastewater and landfill leachate from solid waste landfills. The work can serve as a reference document for researchers working in the field of AOPs, focusing in particular on ozone-based AOPs for wastewater treatment and management systems.

An advantage of chemical oxidation processes, including ozonation, is that they can lead to a total degradation of chemical compounds to carbon dioxide or to transformation of (highly hydrophobic organics) organics to more polar biodegradable molecules [51,53,107,120]. Advanced oxidation processes (AOPs) belong to a group of very promising processes which involve the formation of highly reactive $\mathrm{HO}^{\bullet}$ radicals as an oxidant [29]. Ozone-based AOPs are the most commonly applied in drinking water treatment to oxidize resistant compounds such as pesticides, as well as aromatic and chlorinated compounds [47].

Ozone-based reactions have high oxidative potential. Ozone can react with organics directly (ozonolysis) or via a radical mechanism by means of hydroxyl radicals (e.g., at higher $\mathrm{pH}$, in combination with $\mathrm{H}_{2} \mathrm{O}_{2}$ or $\mathrm{UV}$, etc.). Direct reactions are selective, e.g., for compounds containing unsaturated bounds [49]. Indirect/radical reactions are nonselective [31]. Hydroxyl radicals produced by AOPs have a higher oxidation potential (2.8 V) than molecular ozone $(2.07 \mathrm{~V})$; therefore, they attack organic and inorganic molecules nonselectively at a very high reaction rate [121]. Selective reactions of ozone can be advantageous for controlled oxidation with the aim of decreasing/removing toxicity and increasing the biodegradability of pollutants since total mineralization by ozone is very expensive. Thus, new oxidation processes are developed for the elimination of toxic compounds and for the partial oxidation of persistent organic pollutants from wastewaters. Hence, organics that are highly or completely resistant to conventional biological treatment can be totally mineralized using a combined chemical-biological system [91].

Ormad et al. [122] monitored the effectiveness of pesticide removal by processes commonly used in drinking water treatment in Spain and in the river Ebro. The following processes were investigated: chlorine/ozone oxidation, chemical precipitation with $\mathrm{Al}_{2}\left(\mathrm{SO}_{4}\right)_{3}$, and adsorption on activated carbon (AC). Oxidation with chlorine removed $60 \%$ of the studied pesticides, and efficiency increased when this process was combined 
with separation methods such as flocculation or coagulation. The main disadvantage of this process, as well as of all processes with halogenated oxidizing agents, is the formation of trihalomethane. Ozonation removed $70 \%$ of the monitored pesticides, and efficiency increased to $90 \%$ for combined processes of $\mathrm{O}_{3} /$ coagulation, $\mathrm{O}_{3}$ / flocculation, etc.

Another study presented by Ormad et al. [123] monitored the effectiveness of pesticide removal after the addition of hydrogen peroxide and titanium dioxide to ozone, where the effectiveness of the removal of 44 pesticides present in natural water found in the river Ebro (Spain) was monitored.

Žgajnar Gotvajn et al. [124] investigated the effectiveness of the ozonation and $\mathrm{O}_{3} / \mathrm{H}_{2} \mathrm{O}_{2}$ processes in increasing the biotreatability of the persistent veterinary antibiotic tiamulin in a jet-loop reactor. At ozone doses of $69 \mathrm{gozone} \cdot \mathrm{g}^{-1} \mathrm{COD}$ and $220 \mathrm{~g}_{\text {ozone }} \cdot \mathrm{g}^{-1}$ TOC, the removal of COD and TOC was $26 \%$ and $17 \%$, respectively. The addition of hydrogen peroxide $\left(\mathrm{O}_{3} / \mathrm{H}_{2} \mathrm{O}_{2}\right)$ did not improve the removal efficiency of tiamulin according to the COD and TOC parameters (11-13\%). Changes in biodegradability were determined by respirometric measurements. In the sample treated with the $\mathrm{O}_{3} / \mathrm{H}_{2} \mathrm{O}_{2}$ process, the nitrification process was reduced, especially the formation of $\mathrm{N}^{-\mathrm{NO}_{2}}{ }^{-}$in the first phase of the process. The second stage of nitrification was suppressed by the addition of tiamulin, and ozonation again recovered the formation of $\mathrm{N}^{-\mathrm{NO}_{3}}{ }^{-}$. Simultaneously, a quadratic model was developed that describes the relationship between the rate of oxygen uptake and changes in ammonium nitrogen concentration due to oxidative treatment. The positive effect of ozone was also confirmed by ozonation of waste sludge contaminated with tiamulin, where the potential for biogas production increased sixfold. The results showed that $\mathrm{O}_{3}$ effectively increases the treatability of tiamulin in wastewater and sludge, while the $\mathrm{O}_{3} / \mathrm{H}_{2} \mathrm{O}_{2}$ process generally does not improve process performance.

The study of Ribeiro et al. [3] revealed that there are still many compounds, included in the list of priority substances or defined in Directive 2013/39/EU (such as pesticides aclonifen, bifenox, cybutryn, and quinoxyfen, organometallic tributyltin, dioxins and dioxin-like compounds, brominated diphenyl ethers, hexabromocyclododecans, and bis(2ethylhexyl) phthalate), which have not been studied with AOPs and require the attention of the scientific community. Priority issues are the evaluation of the synergistic, additive, and antagonistic effects between mixtures of compounds in real polluted water matrices, which better reflect real conditions in comparison to the removal of individual MPs.

The combination of membrane filtration with ozonation or AOPs can increase the degradation of biologically refractory compounds and, consequently, reduce the occurrence of membrane fouling. An efficient combination of membrane filtration with catalytic ozonation would be the implementation of a solid catalyst onto the membrane surface. From the studies presented in [125], it follows that this combined method can be efficient for a reduction in membrane fouling, as well as stimulation of MP removal.

The review by Ribeiro et al. [126] analyzed the impact of water matrix components on oxidation technologies (AOPs), including ozone-based processes aimed at the degradation of MPs. The efficiency of individual MP removal by AOPs is the result of the combined effect of water matrix components, which may have a neutral, inhibitory, or supportive effect on the process and mechanism via which these water components react. Organic species can serve either as inhibitors (by exposure to light, capture, or adsorption) or as promoters (increasing indirect photolysis or catalyst regeneration). Inorganic substances can also be either inhibitors (scavenging effects, formation of less active radicals than hydroxyl, iron complexation, surface adsorption) or promoters (e.g., formation of reactive oxygen species by nitrate ions, further catalysis by iron ions). The role and mechanisms of the individual components of water are still not fully understood. Therefore, further studies are needed to understand the wide range of reactions taking place in complex effluents and to increase the efficiency of AOPs in removing MPs.

Wang et al. [127] performed a systematic study of 943 organic semi-volatile MPs in more than 30 wastewater samples, such as primary, secondary, and tertiary effluents from municipal WWTPs in China. They observed that as much as $87 \%$ of the monitored MP 
total concentration was removed during secondary treatments. The studied advanced processes for the tertiary treatment of wastewater provided removal efficiencies of 32-99\% for different methods. Among these, ozone-based processes showed the highest removal efficiency for all micropollutants. However, some potentially harmful substances, such as PAHs, phosphates, phthalates, and benzothiazoles were still present in the final effluent. This study concluded that advanced tertiary treatment is necessary for the removal of a substantial number of MPs present in municipal wastewater.

Macova et al. [128] monitored the efficiency of organic micropollutant removal from WWTP secondary treatment effluent by means of tertiary advanced processes, such as coagulation, flocculation, flotation, filtration, and ozone-based processes. The authors assessed the efficiency of processes by ecotoxicological parameters such as toxic equivalent concentration (TEQ), which represents the concentration of the model compound that invokes a response identical to the unknown and unidentified mixture of micropollutants present in sample. Results showed that, during the primary and secondary treatment in WWTP, no significant decrease in micropollutant concentration occurred. However advanced tertiary treatment could drastically decrease the toxicity of the final effluent.

Sánchez-Polo et al. [129] presented an $\mathrm{O}_{3}$ /granular activated carbon (GAC) system for the enhancement of ozone transformation into radical intermediates ( $\mathrm{HO}^{\bullet}$ radicals). The effectivity of the $\mathrm{O}_{3} / \mathrm{GAC}$ system was compared with conventional AOPs such as $\mathrm{O}_{3} / \mathrm{HO}^{-}$and $\mathrm{O}_{3} / \mathrm{H}_{2} \mathrm{O}_{2}$. The results obtained showed that, under the studied experimental conditions, $\mathrm{O}_{3} / \mathrm{HO}^{-}$and $\mathrm{O}_{3} / \mathrm{H}_{2} \mathrm{O}_{2}$ processes were more efficient in ozone transformation enhancement than $\mathrm{O}_{3} / \mathrm{GAC}$. However, the $\mathrm{O}_{3} /$ GAC process was applied for the remediation of Lake Zurich water, where it led to the removal of micropollutants (both hydrophilic and hydrophobic), as well as a decrease in $\mathrm{CO}_{3}{ }^{2-} / \mathrm{HCO}_{3}{ }^{-}$and $\mathrm{DOC}$ concentrations.

Comninellis et al. [130] in their work summarized advances and trends in advanced oxidation technologies for water, wastewater, air, and soil treatment for research and development purposes. The authors discussed and identified certain topics for the advancement of research and development such as the developments of new materials, as well as modeling and scale-up.

Bui et al. [131] provided a review of advanced methods for the removal of various recalcitrant MPs from wastewaters applied on a large scale. Among the studied methods were AOPs, adsorption, membrane processes, and membrane bioreactors. The authors stated that despite the great number of papers on MP removal at a laboratory scale, only a few full- or even pilot- scale studies were performed. This review, therefore, serves as a reference for the possible practical application of advanced MP removal methods.

In the study of Jin et al. [132], kinetic data for direct and indirect ozone reactions with emerging micropollutants were summarized. Among emerging micropollutants, 24 compounds with different structures and applications (endocrine disruptors, personal care products, and pharmaceuticals) were selected, and their second-order reaction rate constants $\left(\mathrm{k}_{\mathrm{O} 3}\right.$ and $\left.\mathrm{k}_{\mathrm{HO}}\right)$ were determined. All compounds were highly reactive with hydroxyl radicals despite their structural diversity. Reactions with molecular ozone were highly selective in relation to electrophilic ozone reactions. Combined processes such as $\mathrm{UV} / \mathrm{H}_{2} \mathrm{O}_{2}$ or $\mathrm{O}_{3} / \mathrm{H}_{2} \mathrm{O}_{2}$ were suggested as viable alternatives for compounds with low ozone reactivity.

\section{1. $\mathrm{O}_{3} / \mathrm{HO}^{-}$(at Basic $\left.\mathrm{pH}\right)$}

Ozone decomposes in water to form $\mathrm{HO}^{\bullet}$ radicals which are stronger oxidizing agents than ozone itself, thus inducing so-called indirect ozonation. Ozone decomposition in water can be initiated by the hydroxyl anion, $\mathrm{HO}^{-}$, and indirect ozone oxidation is favored under alkaline $\mathrm{pH}$ conditions $[133,134]$.

The rate of $\mathrm{HO}^{\bullet}$ radical formation is dependent on $\mathrm{pH}$ [42]. Usually, under acidic conditions, direct ozonolysis prevails. At basic $\mathrm{pH}$, the reaction mechanism changes to indirect (radical pathway). Direct oxidation of organic compounds by ozone is a more selective reaction with a low reaction rate constant, compared to the radical mechanism [27]. 
The indirect reaction presents a radical mechanism, where radical intermediates are produced during ozone decomposition. The most commonly produced radical is the hydroxyl radical $\left(\mathrm{HO}^{\bullet}\right)$, a nonselective and highly reactive molecule with very high redox potential (2.7 V vs. SHE) [39]. The formed $\mathrm{HO}^{\bullet}$ radicals react with the dissolved organic substances. Many organic and inorganic compounds react with the $\mathrm{HO}^{\bullet}$ radical to form secondary radicals, which leads to termination of the radical chain reaction [135].

Beltrán et al. [136] investigated the ozonation process for the removal of the priority pollutant atrazine. The results of their work showed that the ozonation of atrazine at neutral $\mathrm{pH}$ took place mainly via a radical (indirect) mechanism. The overall rate constant of the direct reaction with ozone was very low $\left(6.31 \mathrm{M}^{-1} \cdot \mathrm{s}^{-1}\right)$ at $20^{\circ} \mathrm{C}$; hence, the radical mechanism may be a priority even at lower $\mathrm{pH}$ values. In addition, this process is dependent on the presence of impurities that promote the decomposition of ozone and/or promoters, releasing superoxide radical anions and hydroxyl radicals.

Begum and Gautam [137] used ozone in their work as a strong oxidizing agent in the degradation of lindane and endosulfan. They found that the optimal dose of ozone $\left(57 \mathrm{mg}_{\text {ozone }} \cdot \mathrm{min}^{-1}\right)$ for the degradation of endosulfan (89\%) and lindane $(43 \%)$. They found that the $\mathrm{pH}$ of the reaction systems greatly affected the degradation efficiency and confirmed that alkaline conditions supported the indirect ozonation mechanism; therefore, they chose $\mathrm{pH} 10$ as the optimal $\mathrm{pH}$ for endosulfan degradation, achieving $93 \%$ efficiency. The optimal $\mathrm{pH}$ for lindane degradation was $\mathrm{pH} 12$, where $82 \%$ efficiency was observed. Evaluating the kinetics of the processes, they concluded that the indirect ozonation of endosulfan and lindane is governed by a first-order reaction. Analysis by gas chromatography showed that endosulfan was degraded to methylcyclohexane and orthoxylene, and lindane was degraded to 1-hexene, indicating cleavage of the cyclic lindane molecule.

Another study [138] investigated the application of ozonation as a pretreatment for water containing pharmaceuticals. Experiments were carried out different water matrices. The degradation efficiencies of studied pharmaceuticals (antibiotics, estrogens, acidic, and neutral) were determined, and the effect of ozone dose and $\mathrm{pH}$ on the degradation efficiency was monitored. The efficiency of oxidation of antibiotics, estrogens, and neutral pharmaceuticals increased as the ozone dose and $\mathrm{pH}$ increased. Average specific ozone doses of $2.05 \mathrm{mg}_{\text {ozone }} \cdot \mathrm{mg}^{-1}$ DOC for antibiotics, $1.11 \mathrm{mg}$ ozone $\cdot \mathrm{mg}^{-1}$ DOC for estrogens, and $1.30 \mathrm{mg}_{\mathrm{ozone}} \cdot \mathrm{mg}^{-1} \mathrm{DOC}$ for neutral pharmaceuticals significantly reduced the acute toxicity of the water solutions and mineralized by more than $40 \%, 33 \%$, and $23 \%$ with respect to DOC, respectively, in $1 \mathrm{~min}$. The kinetics of the ozone reaction with pharmaceuticals was modeled as an overall second-order reaction with a rate constant in the interval $10^{3}$ to $10^{6} \mathrm{M}^{-1} \cdot \mathrm{s}^{-1}$. Ozone-based AOPs were successful in removing emerging pharmaceuticals from the water matrix. It was confirmed that ozonation is more effective than other conventional oxidation processes $\left(\mathrm{Cl}_{2}\right.$ and $\left.\mathrm{ClO}_{2}\right)$ in eliminating pharmaceuticals and in producing less toxic products and byproducts.

The study by Usharani et al. [139] presented the results of the ozonation of methylparathion in aqueous solutions at different $\mathrm{pH}$ performed with synthetic wastewater in a batch reactor. Ozonation was more effective in alkaline $\mathrm{pH}$. The degree of methylparathion conversion reached $98 \%$ after $2 \mathrm{~h}$ at $\mathrm{pH} 9$ and $81 \%$ and $60 \%$ at $\mathrm{pH} 7$ and 3 , respectively. Methylparathion degradation and COD reduction kinetics obtained during ozonation fit a pseudo-first-order mechanism. Pseudo-first-order rate constants at various $\mathrm{pH}$ values were in the range of $0.01-70.028 \mathrm{~min}^{-1}$. The rate constants for COD reduction were in the interval of $0.022-0.047 \mathrm{~min}^{-1}$. In addition, the relatively high values of correlation coefficient $R_{Y X}$ confirmed the applicability of this pseudo-first-order model to methylparathion oxidation via ozonation.

\section{2. $\mathrm{O}_{3} / \mathrm{H}_{2} \mathrm{O}_{2}$}

The system of hydrogen peroxide and ozone is also commonly called the peroxone system. The peroxone system is one of the AOPs in which the production of highly reactive 
radical intermediates (e.g., $\mathrm{HO}^{\bullet}$ ) is involved. The peroxone system was first described by Staehelin and Hoigné [140], when they assumed that the reaction proceeded with the hydrogen peroxide anion (1) and preliminarily suggested that the first step of the reaction was electron transfer (2).

$$
\begin{gathered}
\mathrm{H}_{2} \mathrm{O}_{2} \rightleftharpoons \mathrm{HO}_{2}{ }^{-}+\mathrm{H}^{+} \\
\mathrm{HO}_{2}{ }^{-}+\mathrm{O}_{3} \rightarrow \mathrm{HO}_{2}{ }^{\bullet}+\mathrm{O}_{3}^{\bullet-}
\end{gathered}
$$

$\mathrm{HO}_{2}{ }^{\bullet}$ is in equilibrium with $\mathrm{O}_{2}{ }^{\bullet-}$ (Equation (3)) and it has been assumed that $\mathrm{O}_{3}{ }^{\bullet-}$ (Equation (4)) undergoes protonation, before further decomposing into $\mathrm{O}_{2}$ and $\mathrm{HO} \bullet$ (Equation (5)), while $\mathrm{O}_{2}{ }^{\bullet-}$ undergoes electron transfer with $\mathrm{O}_{3}$ to form another molecule of $\mathrm{HO}^{\bullet}\left(\right.$ via $\left._{3}{ }^{\bullet-}\right)$.

$$
\begin{gathered}
\mathrm{HO}_{2}^{\bullet} \rightleftharpoons \mathrm{O}_{2}^{\bullet-}+\mathrm{H}^{+} \\
\mathrm{O}_{3}^{\bullet-}+\mathrm{H}^{+} \rightleftharpoons \mathrm{HO}_{3}^{\bullet} \\
\mathrm{HO}_{3}^{\bullet} \rightarrow \mathrm{O}_{2}+\mathrm{HO}^{\bullet} \\
\mathrm{O}_{2}^{\bullet-}+\mathrm{O}_{3} \rightarrow \mathrm{O}_{2}+\mathrm{O}_{3}^{\bullet-}
\end{gathered}
$$

As a result, two moles of $\mathrm{H}_{2} \mathrm{O}_{2}$ and two moles of $\mathrm{O}_{3}$ should be produced from one mole of $\mathrm{H}_{2} \mathrm{O}_{2}$ (total reaction: Equation (7)) [140].

$$
\mathrm{H}_{2} \mathrm{O}_{2}+2 \mathrm{O}_{3} \rightarrow 2 \mathrm{HO}^{\bullet}+3 \mathrm{O}_{2}
$$

The peroxone system is a suitable method for generating $\mathrm{HO}^{\bullet}$ radicals. Many studies have confirmed that the peroxone system is capable of dehalogenating, degrading, and mineralizing organic and inorganic pollutants in water and wastewater [141]. Volk et al. [142] studied the effect of ozone, $\mathrm{O}_{3} / \mathrm{H}_{2} \mathrm{O}_{2}$, and catalytic ozone processes. The oxidation system that degraded the highest DOC amount was observed with $\mathrm{O}_{3} / \mathrm{H}_{2} \mathrm{O}_{2}$ $\left(0.35 \mathrm{mg}_{\text {peroxide }} \cdot \mathrm{mg}^{-1}\right.$ ozone $)$. Ozone mineralized $15 \%$, the $\mathrm{O}_{3} / \mathrm{H}_{2} \mathrm{O}_{2}$ system mineralized $18 \%$, and catalytic ozone (10 g of catalyst per $1 \mathrm{~L}$ water) mineralized $24 \%$ of the initial DOC.

Merényi et al. [143] proposed some changes in reaction mechanisms on the basis of their obtained thermo-kinetic and quantum-chemical data. They replaced the first reaction step (Equations (1) and (2)) with the formation of an adduct (Equation (8)), which subsequently decomposed into a hydroperoxyl radical and $\mathrm{HO}_{2}{ }^{\bullet}$ and $\mathrm{O}_{3}{ }^{\bullet-}$ (Equation (9)). As in the original mechanism, $\mathrm{HO}_{2}$ is in equilibrium with $\mathrm{O}_{2}{ }^{\bullet-}$ (Equation (3)), and $\mathrm{O}_{2}{ }^{\bullet-}$ is subsequently subjected to electron transfer with $\mathrm{O}_{3}$ to form $\mathrm{O}_{3}{ }^{\bullet-}$ (Equation (6)). The decomposition of $\mathrm{O}_{3}{ }^{\bullet-}$ to $\mathrm{HO}^{\bullet}$ is further assumed according to Equations (10) and (11), omitting $\mathrm{HO}_{3} \cdot$ as the original intermediate. Following the observation that the peroxone system is only $50 \%$ efficient, the decomposition of $\mathrm{HO}_{5}^{-}$(Equation (12)) was proposed as competitive for the decomposition to $\mathrm{HO}_{2}{ }^{\bullet}$ and $\mathrm{O}_{3}{ }^{\bullet-}$ (Equation (9)).

$$
\begin{gathered}
\mathrm{HO}_{2}{ }^{-}+\mathrm{O}_{3} \rightarrow \mathrm{HO}_{5}^{-} \\
\mathrm{HO}_{2}{ }^{-}+\mathrm{O}_{3} \rightarrow \mathrm{HO}_{5}{ }^{-} \\
\mathrm{O}_{3}{ }^{-} \rightleftharpoons \mathrm{O}_{2}+\mathrm{O}^{\bullet-} \\
\mathrm{O}^{\bullet-}+\mathrm{H}_{2} \mathrm{O} \rightleftarrows \mathrm{HO}+\mathrm{HO}^{-} \\
\mathrm{HO}_{5}{ }^{-} \rightarrow 2 \mathrm{O}_{2}+\mathrm{HO}^{-}
\end{gathered}
$$

Catalkaya and Kargi [144] focused on the dehalogenation, degradation, and mineralization of the diuron herbicide. At low initial concentrations of diuron, dehalogenation and degradation occurred via the mechanism of indirect ozonation; therefore, the amount of removed diuron and AOX (adsorbable organic halogens) increased with increasing $\mathrm{pH}$ (since indirect ozonation takes place in the presence of $\mathrm{HO}^{-}$ions). At high initial concentrations of diuron, the addition of hydrogen peroxide was necessary for its effective removal, which decreased with increasing $\mathrm{pH}$ since the oxidation of peroxide takes place 
preferably at low $\mathrm{pH}$. The first step in the degradation of diuron was dehalogenation, which required the presence of ozone in the absence of $\mathrm{H}_{2} \mathrm{O}_{2}$. TOC removal increased with increasing peroxide addition and decreasing diuron concentration. Alkaline $\mathrm{pH}$ was also advantageous for TOC removal efficiency. AOX removal proceeded in a manner similar to diuron degradation. Alkaline $\mathrm{pH}$ promoted efficient AOX removal because dehalogenation was performed by indirect ozonation, requiring $\mathrm{HO}^{-}$ions. High doses of peroxide caused a reduction in AOX removal rate because of high doses of peroxide as a scavenger of hydroxyl radicals produced by indirect ozonation. Optimal operating conditions varied depending on the dose of diuron. The authors observed almost complete removal of AOX and diuron.

Qiang et al. [145] proposed a mechanism for the degradation of alachlor by direct ozonation or hydroxyl radicals. Upon direct ozonation, ozone may attack the ethyl, $\mathrm{N}$ methoxymethyl, or chloroacetyl group or the benzene nucleus. Previous studies have suggested that the primary ozonation product of alachlor should be a compound with one ethyl group converted to an acetyl group. In addition to the oxidation of the arylethyl group, the cleavage of the $\mathrm{N}$-methoxymethyl group is an important feature of the environmental degradation of alachlor. The $\mathrm{N}$-dealkylation mechanism has been studied in previous work in the oxidation of atrazine by ozone [146]. In general, dehalogenation was not present during direct ozonation. The ozone molecule cannot easily remove chlorine. In the $\mathrm{O}_{3} / \mathrm{H}_{2} \mathrm{O}_{2}$ system, byproducts were generated following oxidation of the arylethyl group with $\mathrm{HO}^{\bullet}$ radicals. Similar to direct ozonation, smaller organic acids were produced during the cleavage of the benzene nucleus. The observed continuous chlorine production implies the dehalogenation of alachlor after the attack by $\mathrm{HO}^{\bullet}$ radicals. 2-Hydroxy-2',6'-diethyl- $\mathrm{N}$ (methoxymethyl) acetanilide was the expected dehalogenation product.

Wert et al. [147] applied ozonation and $\mathrm{O}_{3} / \mathrm{H}_{2} \mathrm{O}_{2}$ processes to treat effluent after a tertiary phase defined by effluent organic matter (EfOM) containing 31 organic micropollutants including endocrine disruptors, pharmaceuticals, and personal care products. The applied ozone dosage was determined upon TOC and nitrite content in the effluent. The authors compared the effectivity of direct and indirect ozone reactions on TOC removal efficiency. Kinetic data obtained from these experiments allowed identifying the micropollutants that were susceptible to ozone degradation and singled out substances such as atrazine, diazepam, ibuprofen, and isopromide which could indicate the $\mathrm{HO}^{\bullet}$ availability in the system.

\section{3. $\mathrm{O}_{3} / \mathrm{UV}$}

Ozonation alone does not always generate enough hydroxyl radicals to degrade organic pollutants. Consequently, complete mineralization does not occur. Higher concentrations of hydroxyl radicals are required for the sufficient degradation of pollutants. The combined process of ozonation with UV radiation quickly generates a large amount of hydroxyl radicals. Therefore, it has become one of the most widely used AOPs for the degradation of organic pollutants [148]. Ozone strongly absorbs UV radiation at a wavelength of $254 \mathrm{~nm}$. The formation of hydroxyl radicals is a two-step process. First, photo-induced homolysis of the ozone molecule takes place (Equation (13)).

$$
\mathrm{O}_{3}+\mathrm{h} v \rightarrow \mathrm{O}_{2}+\mathrm{O}(1 \mathrm{D})
$$

It then reacts with atomic oxygen to form hydroxyl radicals [149] (Equation (14)).

$$
\mathrm{O}(1 \mathrm{D})+\mathrm{H}_{2} \mathrm{O} \rightarrow \mathrm{H}_{2} \mathrm{O}_{2} \rightarrow 2 \mathrm{HO}^{\bullet}
$$

Hydroxyl radicals further react with organic substances. In the presence of UV radiation, the kinetics of the whole process is accelerated [148].

The oxidation of organophosphorus pesticides malathion and parathion, in aqueous solution, was studied by Beduk et al. [150] using photolytic ozonation (among other processes). They performed batch experiments $\left(c_{0}=200 \mu \mathrm{g} \cdot \mathrm{L}^{-1}\right)$ with the aim of determining 
the efficiencies of the studied processes. The $\mathrm{O}_{3} / \mathrm{UV}$ system was able to degrade both pesticides, while also leading to detoxication of the final oxidation products.

Abrile et al. [151] studied the degradation of recalcitrant reactive dye Reactive Blue 19 (RB 19) by means of ozonation and combined ozonation with UV irradiation processes with the aim of optimizing process parameters such as $\mathrm{pH}$, ozone dose, and UV irradiation intensity. The authors used response surface methodology to determine optimal operational conditions in terms of the half-time of RB 19 discoloration and further mineralization of the sample. The obtained data confirmed the fit between the model and experimental results and also proved ozone-based processes as an efficient method for the treatment of wastewater with a high content of industrial dyes.

The combination of advanced oxidation process and direct contact membrane distillation (DCMD) was investigated for a municipal wastewater treatment plant treatment effluent [152]. Average removal efficiencies of the 12 micropollutants present in the wastewater exceeded $95 \%$ with ozonation and $\mathrm{UV} / \mathrm{O}_{3}$. The concentrations of these micropollutants were below the detection limits, and an increase in the quality of the treated water was observed after the ozone-based processes were combined with DCMD. The combination of oxidation and membrane separation processes is more appropriate for wastewaters with low DOC content due to its strong impact on the permeate fluxes achieved by DCMD.

\section{4. $\mathrm{O}_{3} / \mathrm{UV} / \mathrm{H}_{2} \mathrm{O}_{2}$}

The combination of $\mathrm{O}_{3} / \mathrm{UV} / \mathrm{H}_{2} \mathrm{O}_{2}$ is more efficient than processes involving ozonation alone, $\mathrm{O}_{3} / \mathrm{H}_{2} \mathrm{O}_{2}$, or $\mathrm{UV} / \mathrm{H}_{2} \mathrm{O}_{2}$. In this process, ozone decomposes into hydroxyl radicals. UV radiation $(254 \mathrm{~nm})$ helps the ozone molecules to activate faster, and the presence of hydrogen peroxide increases the rate of the reaction. The resulting radicals attack organic pollutants and are even able to mineralize them to carbon dioxide and water. The $\mathrm{O}_{3} / \mathrm{UV} / \mathrm{H}_{2} \mathrm{O}_{2}$ system can be described by the reactions below (Equations (15)-(19)) [153].

$$
\begin{gathered}
\mathrm{O}_{3}+\mathrm{H}_{2} \mathrm{O}_{2}+\mathrm{h} v \rightarrow \mathrm{HO}^{\bullet}+\mathrm{O}_{2}+\mathrm{HO}_{2}^{\bullet} \\
\mathrm{O}_{3}+\mathrm{HO}^{\bullet} \rightarrow \mathrm{HO}_{2}^{\bullet}+\mathrm{O}_{2} \\
\mathrm{O}_{3}+\mathrm{HO}_{2}^{\bullet} \rightarrow \mathrm{HO}^{\bullet}+2 \mathrm{O}_{2} \\
\mathrm{HO}^{\bullet}+\mathrm{HO}_{2}^{\bullet} \rightarrow \mathrm{H}_{2} \mathrm{O}+\mathrm{O}_{2} \\
2 \mathrm{HO}^{\bullet} \rightarrow \mathrm{H}_{2} \mathrm{O}
\end{gathered}
$$

Zangeneh et al. [154] performed a comparative study of several AOP systems in the photo-oxidation of industrial wastewater containing linear alkyl benzene (LAB). After an analysis of the process, four independent variables were selected (initial $\mathrm{pH}$ and $\mathrm{H}_{2} \mathrm{O}_{2}$ concentration, as well as UV radiation and ozonation) as categorical factors. The efficiency of the systems was compared in terms of total COD removal and changes in $\mathrm{BOD}_{5} / \mathrm{COD}$ ratio. The maximum COD removal efficiencies were $58 \%, 53 \%, 51 \%$, and $49 \%$ for the $\mathrm{UV} / \mathrm{H}_{2} \mathrm{O}_{2} / \mathrm{O}_{3}, \mathrm{H}_{2} \mathrm{O}_{2} / \mathrm{O}_{3}, \mathrm{UV} / \mathrm{O}_{3}$, and $\mathrm{UV} \mathrm{H}_{2} \mathrm{O}_{2}$ systems, respectively, under optimal conditions ( $\mathrm{pH}=7 ; 100 \mathrm{mM} \mathrm{H}_{2} \mathrm{O}_{2}$ concentration; reaction time $\left.=180 \mathrm{~min}\right)$. A significant increase in $\mathrm{BOD}_{5} / \mathrm{COD}$ was observed for combined processes as opposed to the utilization of a single oxidant.

The UV-induced degradation and mineralization of paracetamol was investigated in a study by Bavasso [155]. Two advanced oxidation processes based on the photolysis of electrogenerated hydrogen peroxide $\left(\mathrm{H}_{2} \mathrm{O}_{2}\right)$, and ozone were compared. The $\mathrm{H}_{2} \mathrm{O}_{2}$ electrosynthesis has been performed via oxygen reduction on gas diffusion electrodes (GDEs). The effect of the main operative parameters (reagent concentration, $\mathrm{pH}$, current density, UV irradiance) was evaluated. Due to the synergistic effect, paracetamol underwent rapid degradation and extensive mineralization. Photolysis provided the fastest removal of paracetamol leading to complete removal in $10 \mathrm{~min}$ and $91.5 \%$ mineralization. The rate-determining step for hydroxyl radical production was UV irradiance. 


\subsection{Homogeneous Catalytic Ozonation}

The mechanism of catalytic ozonation is based on ozone decomposition, followed by the production of radicals (mainly $\mathrm{O}_{2}{ }^{\bullet-}, \mathrm{O}_{3}{ }^{\bullet}$, and $\mathrm{HO}^{\bullet}$ ) [156].

Catalytic ozonation may be an effective way to increase the rate of oxidation [157]. The benefits provided by the utilization of an ozone-based catalytic system have been demonstrated for the removal of organic pollutants such as atrazine, chlorobenzenes, and halocarbons $[141,158,159]$. Homogenous catalytic ozonation can be effective in the removal of pollutants from water, but the disadvantage of this technology is the addition of metallic ions to the system, which can cause the production of secondary pollution in the form of metal-containing sludge [156].

The review by Nawrocki and Kasprzyk-Hordern [160] summarized advances in catalytic ozonation process. The authors compared different experimental data with the aim of understanding and describing the reaction pathways of catalytic ozonation, which are still largely unknown. Results suggested that, even though catalytic ozonation is an AOP, not all catalytic processes utilize the reactivity of $\mathrm{HO}^{\bullet}$ radicals.

\subsection{1. $\mathrm{O}_{3} /$ Transition Metal Ions}

Transition metal ions belong to the most used homogenous catalysts in $\mathrm{O}_{3} /$ metal ion systems. These ions are $\mathrm{Fe}^{2+}, \mathrm{Mn}^{2+}, \mathrm{Ni}^{2+}, \mathrm{Co}^{2+}, \mathrm{Cd}^{2+}, \mathrm{Cu}^{2+}, \mathrm{Ag}^{+}, \mathrm{Cr}^{2+}$, and $\mathrm{Zn}^{2+}$. In these systems, metal ions are rate-determining factors that also affect the selectivity of the $\mathrm{O}_{3} /$ metal ion system and utilization of ozone [161].

Farré et al. [162] applied both homogeneous and heterogeneous ozonation (in the presence of UV) for the degradation of biorecalcitrant organic compounds. Selected compounds were pesticides such as alachlor, atrazine, chorofenvinfos, diuron, isoproturon, and pentachorophenol. The experimental solution contained $50 \mathrm{mg} \cdot \mathrm{L}^{-1}$ of each pesticide, and the $\mathrm{pH}$ was kept at acidic levels $(\mathrm{pH}=3)$. The presence of dissolved ozone in the irradiated aqueous suspension increased the $\mathrm{HO}^{\bullet}$ radical production and decreased the electron-hole recombination, subsequently increasing the efficiency of the photocatalytic process.

Psaltou et al. [163] investigated homogeneous catalytic ozonation with the addition of dissolved metal ions for the removal/degradation of small concentrations of $p$-CBA from aqueous solutions. Different transition metal ions $\left(\mathrm{Co}^{2+}, \mathrm{Fe}^{2+}, \mathrm{Mn}^{2+}, \mathrm{Ni}^{2+}\right.$, and $\left.\mathrm{Zn}^{2+}\right)$ were studied $\left(\mathrm{pH}=7 ; 0.25-1 \mathrm{mg} \mathrm{L}^{-1}\right) . \mathrm{O}_{3} / \mathrm{Co}^{2+}$ and $\mathrm{O}_{3} / \mathrm{Fe}^{2+}$ systems were the only effective catalytic ozonation processes. Accordingly, $95.5 \%$ and $92.5 \% p$-CBA degradation was determined due to the low solubility of respectively formed oxy-hydroxides $\left(\mathrm{Co}(\mathrm{OH})_{3}\right.$ and $\left.\mathrm{Fe}(\mathrm{OH})_{3}\right)$. The optimal catalyst concentration was $1 \mathrm{mg} \cdot \mathrm{L}^{-1}$, ozone concentration was $2 \mathrm{mg} \cdot \mathrm{L}^{-1}$, and $\mathrm{pH}$ was 8 . The $p$-CBA concentration dropped below the analytical detection limit of $0.025 \mu \mathrm{M}$ after only $3 \mathrm{~min}$ of reaction/oxidation time. The addition of Co(II) and $\mathrm{Fe}(\mathrm{II})$ increased the decomposition of ozone, as well as the production of hydroxyl radicals, leading to faster and more effective $p$-CBA degradation.

\subsection{2. $\mathrm{O}_{3} / \mathrm{US}$}

Ibáñez et al. [56] investigated ozone-based processes for the removal of 60 emerging MPs present in wastewater at a pilot-plant scale. MPs were determined using LC-MS/MS in WWTP influent and effluent. Results suggested that at least 30 MPs were successfully removed in the biological step of municipal WWTP. However, some antibiotics, antiinflammatory drugs, drugs of abuse, and cholesterol-lowering drugs were still present in the effluent from WWTP. Tertiary treatment by ozone was applied and resulted in a substantial decrease in MP concentration. Ultrasound and ultrasound in combination with ozone were also applied with the aim of increasing the efficiency of ozone treatment but were proven redundant with no to very low impact on the overall efficiency.

Kidak et al. [164] investigated the treatment of an antibiotic amoxicillin using mediumhigh-frequency ultrasonic (US) irradiation and/or ozonation. The ultrasonic irradiation process was carried out in a batch reactor for aqueous amoxicillin solutions at three different frequencies $(575,861$, and $1141 \mathrm{kHz})$. The highest removal was achieved at $575 \mathrm{kHz}$ 
(>99\%) with a pseudo-first-order reaction rate constant of $0.04 \mathrm{~min}^{-1}$ at $\mathrm{pH} \mathrm{10,} \mathrm{but} \mathrm{the}$ mineralization was only $10 \%$. Alkalinity and the presence of humic acids negatively affected the removal efficiency ( $50 \%$ decrease). Ozone removed amoxicillin 50 times faster than US. Coupling of ozone and US increased the rate constant several hundredfold. In the ozonation processes, humic acid did not show any significant effect because the rate constant was very high. It was concluded that the hybrid advanced oxidation system was the best option for amoxicillin removal.

\subsection{Heterogeneous Adsorptive and Catalytic Ozonation}

Heterogeneous AOPs have the advantage of a more simple separation of the product in comparison to homogeneous ones [29].

Lv et al. [165] studied the catalytic ozonation of toxic pollutants, such as 2,4-dichloroph enoxyacetic acid, 2,4-dichlorophenol, and 2,4,6-trichlorophenol, as well as the pharmaceutical phenazone, over magnetic cobalt-doped $\mathrm{Fe}_{3} \mathrm{O}_{4}$ suspensions. Magnetic cobalt-doped $\mathrm{Fe}_{3} \mathrm{O}_{4}(\mathrm{FeCo})$ was prepared by coprecipitation and further characterized by $\mathrm{X}$-ray diffraction, spectroscopy (XPS and ATR-FTIR), and cyclic voltammetry. The catalyst showed high and stable catalytic activity for the degradation of selected pesticides and pharmaceuticals. FeCo was also highly effective in the mineralization of byproducts formed in the degradation of organic pollutants. Ozone was adsorbed on the active sites at the surface of FeCo and then converted into hydroxyl radicals, which diffused quickly to the bulk solution. The introduction of Co into the catalyst enhanced the interfacial electron transfer, which resulted in higher reactivity.

Huang et al. [166] synthesized and characterized catalysts MCM-41 and iron-substituted MCM-41 (Fe/MCM-41) for $p$-chlorobenzoic acid ( $p$-CBA) removal by means of catalytic ozonation. Both catalysts provided high BET surface areas, and analyses suggested that they had a hexagonal structure. Experimental conditions for $p$-CBA were an ozone dose of $100 \mathrm{mg} \cdot \mathrm{h}^{-1}$ and a $p$-CBA initial concentration of $10 \mathrm{mg} \cdot \mathrm{L}^{-1}$ at $\mathrm{pH} 4.3$ with a catalyst dosage $1.0 \mathrm{~g} \cdot \mathrm{L}^{-1}$. TOC removal efficiency by ozonation catalyzed by Fe/MCM-41 reached $94.5 \%$ after $60 \mathrm{~min}$ reaction time, while the corresponding efficiencies were $61.5 \%$ by $\mathrm{MCM}-41 / \mathrm{O}_{3}$, $88.6 \%$ by $\mathrm{Fe}_{2} \mathrm{O}_{3} / \mathrm{O}_{3}$, and $62.3 \%$ by ozonation alone; furthermore, only $2.1 \%$ TOC was removed due to adsorption on Fe/MCM-41. Moreover, reaction kinetics were studied. Results suggested that the $\mathrm{Fe} / \mathrm{MCM}-41 / \mathrm{O}_{3}$ process followed apparent first-order kinetics with a rate constant of $0.480 \mathrm{~min}^{-1}$, while ozonation alone, MCM- $41 / \mathrm{O}_{3}$ and $\mathrm{Fe}_{2} \mathrm{O}_{3} / \mathrm{O}_{3}$ processes followed apparent second-order kinetics.

Liu et al. [167] studied the catalytic ozonation of dye Acid Red B (ARB) in the presence of $\mathrm{Fe}-\mathrm{Cu}$ oxide $(\mathrm{Fe}-\mathrm{Cu}-\mathrm{O})$ catalyst. The authors studied different experimental conditions, such as $\mathrm{pH}$ conditions (3-11), ozone flowrate $\left(3.6-30 \mathrm{mg} \cdot \mathrm{min}^{-1}\right)$, and initial dye concentration $\left(100-500 \mathrm{mg} \cdot \mathrm{L}^{-1}\right)$. The observed parameters for the determination of process efficiency were COD and color removal. Optimal condition for ARB removal were $\mathrm{pH}=6.8$ and ozone flow $=30 \mathrm{mg} / \mathrm{min}$. Under these conditions, after $60 \mathrm{~min}$. color and COD removal rates were $66 \%$ and $48 \%$, respectively, for the ozonation process. Ozonation in the presence of $\mathrm{Fe}-\mathrm{Cu}-\mathrm{O}$ catalyst, under the same experimental conditions, resulted in color and COD removal efficiencies of $90 \%$ and $70 \%$, respectively. Results suggested that the catalytic ozonation of ARB followed pseudo-first-order rate kinetics. The ARB removal mechanism was proposed as an indirect ozonation reaction combined with direct surface oxidation reactions.

Lan et al. [168] synthesized and characterized catalysts MCM-41 and iron-substituted MCM-41 (Fe/MCM-41) for $p$-chlorobenzoic acid ( $p$-CBA) removal by means of catalytic ozonation. Iron-substituted MCM-41 provided high BET surface areas, high pore volumes, and narrow pore size distribution. The efficiency of $p$-CBA catalytic ozonation was evaluated by means of $p$-CBA and TOC removal rates. In Fe/MCM-41-catalyzed ozonation, $100 \%$ removal of $p$-CBA and $91.3 \%$ TOC removal were observed after $10 \mathrm{~min}$ and $60 \mathrm{~min}$, respectively. The authors proposed the reaction mechanism as the formation of hydroxyl radicals on the $\mathrm{Fe} / \mathrm{MCM}-41$ surface. 
Gopi et al. [169] investigated the behavior of 13X zeolite-supported metal oxides in ozone catalytic oxidation (OZCO) of toluene. The activity of the catalyst was ranked in the order of metal ion used $(\mathrm{Mn}>\mathrm{Ce}>\mathrm{Cu}>\mathrm{Ag}>\mathrm{Co}$ ). Results suggested that the amount of decomposed ozone had a direct impact on degree of oxidative decomposition of toluene over the $\mathrm{Mn} / 13 \mathrm{X}$ catalyst.

Larouk et al. [170] studied the catalytic ozonation of azo-dye Orange-G (OG) in the presence of a hematite/SBA-16 mixture (HS). HS exhibited high catalytic activity and led to total discoloration of the reaction mixture in half the time compared to hematite or SBA-16 alone. The authors proposed that OG ozonation is initiated by hydroxylation and desulfonation of the aromatic rings. Assessment of the parameter interactions clearly demonstrated that a simultaneous decrease in catalyst amount and initial $\mathrm{pH}$ is beneficial in terms of reducing the ozonation time. Results showed that ozonation was triggered in the solution bulk, while adsorption was enhanced by the dissolution, diffusion, and adsorption of ozone and $\mathrm{Fe}^{3+}$ cations.

\subsection{1. $\mathrm{O}_{3}$ / Zeolite (ZEO)}

Increased process efficiency can be achieved by adsorbing pollutants and ozone onto the surface of zeolite (ZEO) or activated carbon (GAC), thereby concentrating them. As a result, the concentrations of ozone and MPs in the micropores and apparent rates can be increased compared to the bulk phase. The adsorptive ozonation process was first published by Fujita et al. [171]. They used zeolite as the adsorbent material and studied the degradation of acetaldehyde. To achieve the same residual concentration of acetaldehyde, adsorptive ozonation required a reaction time of approximately two orders of magnitude shorter compared to ozonation alone. The authors attributed the increased efficiency of the process to the adsorption of pollutants and ozone onto the surface of the zeolite, as well as their concentration and, consequently, higher reaction rates.

Valdés et al. [172] studied the effect of various catalysts on ozone decomposition in a combined process aimed at the removal of nonbiodegradable pollutants. Experiments were carried out with low-cost heterogeneous catalysts from natural sources, such as zeolite and volcanic sand. Different $\mathrm{pH}$ conditions and the presence of free-radical scavengers were compared for the effect on dissolved ozone decay. Results suggested that the studied catalysts led to an increased decay rate of ozone. Alkaline conditions inhibited the effect of free-radical scavengers on the self-decomposition of ozone molecules. Results suggested that the decomposition of ozone took place mainly on the surface of the catalyst.

\subsection{2. $\mathrm{O}_{3} /$ Activated Carbon (AC)}

Activated carbon (AC) is used not only as an adsorbent but also as a catalyst in promoting ozone oxidation. Adsorption on activated carbon and ozonation combined into a single process can offer strong synergetic effects on the treatment efficiency of contaminated groundwater and wastewater $[173,174]$.

Xing et al. [175] performed the ozonation of oxalate in the presence of activated carbon (AC) with the aim of studying the effect of different conditions (AC dosage, solution $\mathrm{pH}$, AC surface reactions) on the removal efficiency. Results of the study suggested that AC significantly enhanced the ozonation efficiency of oxalate. Higher doses of AC $\left(0.3 \mathrm{~g} \cdot \mathrm{L}^{-1}\right)$ inhibited the effect of free-radical scavengers (tert-butyl alcohol) at lower $\mathrm{pH}$ levels. AC at a dose of $0.1 \mathrm{~g} \cdot \mathrm{L}^{-1}$ also prevented the inhibition of ozone decomposition by tert-butyl alcohol. The authors suggested that $\mathrm{AC}$ can initiate, promote, or inhibit the radical reaction of ozone decomposition, as well as catalyze surface ozonation reactions. Therefore, AC-catalyzed ozonation can enhance pollution removal and ozone usage efficiency.

Gümüş and Akbal [176] studied the removal of humic acid from aqueous solution using ozone-based processes. Investigated processes were ozonation $\left(\mathrm{O}_{3}\right)$, ozonation catalyzed by iron-coated zeolite ( $\left.\mathrm{ICZ}-\mathrm{O}_{3}\right)$, and ozonation catalyzed by granular activated carbon $\left(\mathrm{GAC}-\mathrm{O}_{3}\right)$. Removal efficiency was evaluated by the removal of DOC and absorbance $\left(\mathrm{UV}_{254}\right.$, specific ultraviolet absorbance at $254 \mathrm{~nm}$ (SUVA), and absorbance at $\left.436 \mathrm{~nm}\right)$. DOC 
removal by ozonation was $21.4 \%$ at an $\mathrm{O}_{3}$ concentration of $10 \mathrm{mg} \cdot \mathrm{L}^{-1}$, $\mathrm{pH}$ equal to 6.5 , and reaction time of $60 \mathrm{~min}$. ICZ- and GAC-catalyzed ozonation led to significant increases in DOC removal of $62 \%$ and $48.1 \%$, respectively, for a catalyst dosage of $0.75 \mathrm{~g} \cdot \mathrm{L}^{-1}$. Results suggested that the ozonation process led to the destruction of unsaturated bonds in humic acid, which led to the discoloration of solution; however, the DOC removal rates were not satisfactory. Catalyzed ozonation promoted the further mineralization of humic substances and was also effective in the color removal of the solution.

Derco et al. [177] studied the $\mathrm{O}_{3} / \mathrm{ZEO}$ and $\mathrm{O}_{3} / \mathrm{GAC}$ processes with model and real wastewaters containing benzothiazole (BT) and its derivatives. Compared to ozonation alone, $10-15 \%$ higher efficiencies were achieved by the $\mathrm{O}_{3} / \mathrm{ZEO}$ process. When using combined $\mathrm{O}_{3} / \mathrm{GAC}$ process, a higher $\mathrm{BT}$ removal rate, improved COD removal efficiency, and a higher degree of mineralization were observed. The efficiency of BT mineralization was approximately threefold higher when using the $\mathrm{O}_{3} / \mathrm{GAC}$ process in comparison to ozonation alone.

When using the combined $\mathrm{O}_{3} / \mathrm{GAC}$ process, a higher $\mathrm{BT}$ removal rate, a higher $\mathrm{COD}$ removal efficiency, and a higher degree of mineralization were also achieved. Ozone reacted selectively, forming a more partially oxidized fraction and significantly higher concentrations of $\mathrm{BTSO}_{3}$. Thus, due to the more efficient partial oxidation, ozonation is more suitable for detoxification and increasing the polarity of BT decomposition products in the raw WW. On the other hand, the $\mathrm{O}_{3} /$ GAC process is more suitable as the tertiary phase of the WWTP to reach the COD effluent discharge limit values [146].

\subsection{3. $\mathrm{O}_{3}$ /Metallic Oxides}

Heterogeneous catalysts are, in comparison with homogenous catalysts, more stable and offer smaller losses upon reaction. Heterogeneous catalysts enhance ozone decomposition, can be recycled from solution, and can be reused. The efficiency of the $\mathrm{O}_{3} /$ metallic oxide process depends strongly on the catalyst, its surface parameters, and the $\mathrm{pH}$ of reaction solution, which affects the properties of active sites on the catalyst surface and ozone decomposition reactions in aqueous solutions [45].

The catalytic efficiency of metal oxides is determined by their physical and chemical properties. Physical properties include surface area, pore size, and surface charge. The main chemical properties include chemical stability and active surface sites. Some metallic oxides, such as $\mathrm{Al}_{2} \mathrm{O}_{3}, \mathrm{MnO}_{2}, \mathrm{TiO}_{2}, \mathrm{ZnO}$, and $\mathrm{FeOOH}$, exhibit excellent catalytic activity as heterogeneous catalysts in the degradation of organic pollutants in aqueous solution $[178,179]$.

In addition to the activation of ozone decomposition, metallic oxides bring another unique feature in $\mathrm{O}_{3} /$ metallic oxide processes, i.e., the promotion of interface and surface reactions. In these reactions, the main function of the catalyst is as an adsorbent material. It first adsorbs onto organic pollutants its large surface and then removes them. Second, it provides active adsorption sites where it combines with organic molecules to form complexes with lower activation energy [180].

Ormad et al. [122] studied the effect of hydrogen peroxide and titanium dioxide on ozone-based processes in the degradation of 44 organic pesticides present in natural water systematically detected in the Ebro river basin (Spain). Ozonation with $3 \mathrm{mg}_{\mathrm{ozone}} \cdot \mathrm{L}^{-1}$ led to the removal of pesticides with an efficiency of almost $23 \%$, while, for $\mathrm{O}_{3} / \mathrm{H}_{2} \mathrm{O}_{2}$ and $\mathrm{O}_{3} / \mathrm{TiO}_{2}$ systems, the degradation efficiency was lower. However, the application of the $\mathrm{O}_{3} / \mathrm{H}_{2} \mathrm{O}_{2} / \mathrm{TiO}_{2}$ process significantly improved the degradation of pesticides and achieved an average degradation efficiency of $36 \%$.

\subsubsection{Nano-Catalyst AOPs}

Recently, nanoparticles have gained attention due to their heightened reactivity in many areas, such as environmental sciences, biology, agriculture, and the pharmaceutical industry. The purpose of this section of the review is to report the important role of 
nanoparticles as nano-catalysts in ozone-based AOPs for water purification and wastewater treatment.

A previous literature review [181] investigated the potential and prospects of nanocatalysts in ozone-based AOPs for the degradation of recalcitrant pollutants. Degradation mechanisms of the nanoparticle-catalyzed AOPs were also described. The application of nanomaterials such as metal nanoparticles, zero-valent metal nanoparticles $\left(\mathrm{Fe}^{0}, \mathrm{Ag}^{0}, \mathrm{Zn}^{0}\right)$, metal oxide nanoparticles $\left(\mathrm{TiO}_{2}, \mathrm{ZnO}, \mathrm{MgO}, \mathrm{MnO}\right)$, carbon nanotubes (CNTs), nano-oxide metals fixed on membranes, and nanocomposites in water and wastewater treatment are becoming specific research subjects [182-184].

In the work of Carbajo et al. [185], a synthetic water matrix and a WWTP influent containing benzalkonium chloride $(\mathrm{BACl})$ and $\mathrm{Ni}$ oxide nanoparticles (NiO-NPs) were pretreated by ozonation. BACl was efficiently removed from the system independently of NP presence; however, NPs influenced ozone dose. BACl mineralization was limited, and byproduct formation was prevalent. The identification of some byproducts suggested possible reaction pathways of ozone-treated $\mathrm{BACl}$, where the authors indicated that both hydrophobic and hydrophilic sites were attacked by ozone, depending on the availability of reaction centers in the presence of NiO-NPs. $\mathrm{BACl}$ showed aquatic toxicity toward the bacteria Vibrio fischeri and Pseudomonas putida and the protozoan Tetrahymena thermophila, as well as microorganisms of activated sludge. Ozone pretreatment lowered the influent toxicity due to $\mathrm{BACl}$ degradation; however, $\mathrm{Ni}$ particles were released from $\mathrm{NiO}-\mathrm{NPs}$, thus increasing wastewater toxicity.

\subsubsection{Use of Multiple Ozone-Based AOPs}

Research by Čehovin et al. [186] focused on the application of selected AOPs in combination with hydrodynamic cavitation for the removal of dissolved organic carbon (DOC) in the form of humic acid dissolved in drinking water. The aim of the study was to reduce the production of disinfection byproducts mainly present in drinking water after the application of a chlorine-based disinfectant. Investigated processes were ozonation and ozone-based advanced oxidation processes, such as $\mathrm{H}_{2} \mathrm{O}_{2} / \mathrm{O}_{3}, \mathrm{H}_{2} \mathrm{O}_{2} / \mathrm{UV}$, and $\mathrm{O}_{3} / \mathrm{UV}$ in combination with hydrodynamic cavitation. The authors observed enhanced DOC removal rates up to $5-15 \%$ when combining AOPs with hydrodynamic cavitation. However, the DBP formation potential in these processes remains to be investigated.

For the assessment of feasibility of ozonation and ozone-based processes, the prices of ozone production should be considered. They depend upon the type of ozone generator, the ozone dose required for effective removal of target pollutants, and the actual price of other chemicals (hydrogen peroxide, catalysts, etc.) and energy used (UV, etc.). An average price of 0.339 EUR per $\mathrm{mg}$ of $\mathrm{O}_{3}$ produced for the optimization of the process of water treatment is highly recommended. The same is also true for waste sludge processing using ozonation [83]. Ozonation of waste sludge prior to anaerobic digestion helps to mainly improve the first step of the process, i.e., hydrolysis, to increase biogas production and methane yield. However, the increase in production of methane due to such a pretreatment could be considerable regarding the incineration of formed methane and its energetic value (heating value of $50 \mathrm{MJ} \cdot \mathrm{kg}^{-1}$ ). Due to the average energy price in EU for non-household consumers (0.135 EUR per kWh; Eurostat, 2020), the tradeoff between price of ozone production and improved energy production should be always addressed. Many authors confirmed that the optimal ozone dose for sludge solubilization is in the range of 0.05 to $0.5 \mathrm{~g} \mathrm{O}_{3} \cdot \mathrm{g}^{-1}$ of total solids, depending on the properties of the sludge and other conditions of the selected pretreatment method [83,187].

\section{Oxidation of Selected Micropollutants by Ozonation and Ozone-Based AOPs}

This section of the paper is aimed at presenting the results of ozone-based degradation, as well as transformation studies of the following groups of micropollutants:

- $\quad$ Alkylphenols (AP): 4-nonylphenol (NP), 4-t-octylphenol (4tOP), nonylphenol ethoxylate (NPEO), and octylphenol ethoxylate (OPEO) by ozonation, $\mathrm{O}_{3} / \mathrm{GAC}$, ozonation 
combined with zeolite $\left(\mathrm{O}_{3} / \mathrm{ZEO}\right)$, modified zeolite with iron $\left(\mathrm{O}_{3} / \mathrm{ZEO}_{\mathrm{Fe}}\right)$, and manganese $\left(\mathrm{O}_{3} / \mathrm{ZEO}_{\mathrm{Mn}}\right)$ processes.

- Petroleum-based substances: benzene, toluene, ethylbenzene, and xylenes (BTEX) by ozonation, $\mathrm{O}_{3} / \mathrm{UV}, \mathrm{O}_{3} / \mathrm{UV} / \mathrm{H}_{2} \mathrm{O}_{2}, \mathrm{O}_{3} / \mathrm{H}_{2} \mathrm{O}_{2}$, and $\mathrm{O}_{3} / \mathrm{UV} / \mathrm{H}_{2} \mathrm{O}_{2}$ processes.

- Organochlorine pesticides: pentachlorobenzene (PCB), hexachlorobenzene (HCB), hexachlorobutadiene (HCBD), lindane ( $\gamma$-isomer of hexachlorocyclohexane) (LIN), and heptachlor (HC) by ozonation, $\mathrm{O}_{3} / \mathrm{UV}, \mathrm{O}_{3} / \mathrm{GAC}, \mathrm{O}_{3} / \mathrm{ZEO}$, and $\mathrm{O}_{3} /$ nZVI processes.

The groups of substances selected above are environmentally relevant chemicals due to their hazardous impacts; thus, they are also listed in various legislative documents and conventions. Hexachlorobutadiene, pentachlorobenzene, hexachlorobenzene, lindane, heptachlor, 4-nonylphenol, and 4-tert-octylphenol are priority hazardous substances. Benzene is a priority substance [5]. Toluene and xylenes are relevant substances. Organochlorine pesticides are persistent substances listed by the Stockholm Convention [10,11].

All homogeneous transformation/removal processes were performed in a jet-loop reactor. A mixture of ozone and oxygen was injected into a wastewater sample through a Venturi ejector. At the same time, the ejector sucked the mixture of $\mathrm{O}_{3}$ and $\mathrm{O}_{2}$ from the reactor headspace. This alignment, together with the external circulation, should improve the efficiency of ozone utilization in the ozonation reactor. Heterogeneous ozone-based processes were carried out in a completely mixed reactor.

\subsection{Alkylphenols (AP)}

In this subsection, the results presented in our papers [188-193] regarding the removal of 4-nonylphenol (NP), 4-t-octylphenol (4tOP), nonylphenol ethoxylate (NPEO), and octylphenolethoxylate (OPEO) from an industrial wastewater by ozonation, adsorptive ozonation $\left(\mathrm{O}_{3} / \mathrm{GAC}, \mathrm{O}_{3} / \mathrm{ZEO}, \mathrm{O}_{3} / \mathrm{ZEO}_{\mathrm{Fe}}, \mathrm{O}_{3} / \mathrm{ZEO}_{\mathrm{Mn}}\right)$, and $\mathrm{O}_{3} / \mathrm{UV}$ processes are reviewed.

Alkylphenols (AP) are toxic, persistent, and endocrine-disrupting chemicals $[50,194]$. 4-Nonylphenol (4NP), 4-octylphenol (4OP), and 4-tert-octylphenol (4tOP) are the three most commonly found in the environment. The isomers of nonylphenol and octylphenol were included in the list of priority substances of the Water Framework Directive [4] and Directive 2013/39/EU [6]. As priority hazardous substances, nonylphenol isomers including 4-nonylphenol have been identified. Octylphenol including isomer 4-tert-octylphenol has the status of a priority substance. Due to their wide use, high biological stability, and estrogenic activity, alkylphenols (AP) are among the most important environmental estrogens [195].

Alkylphenol ethoxylates represent another related and important group of substances. These are generally less toxic; however, in the environment, they easily degrade to the corresponding alkylphenols. The use of alkylphenols and alkylphenol ethoxylates is currently regulated $[6,50,196,197]$.

Nonylphenol (NP) isomers are used as plasticizers and antioxidants in the rubber and plastics industries, as industrial detergents for wool, paper, textile, and pulp processing, for metal surface treatments, as pesticide formulations, and as components of various cosmetic preparations [198]. Their use is also significant in the synthesis of nonylphenol ethoxylates. Nonylphenol ethoxylates (NPEOs) are used in detergents, emulsions, pesticides, and dispersants, as well as in the paper industry as nonionic surfactants. While the toxicity of NPEOs is not as significant, their decomposition is a major source of much more toxic NPs in the environment [50].

The application of ozonation process to enhance the biodegradability of APEOs started in the late 1970s [199]. Even though ozonation itself was responsible for only a 39\% reduction in COD and a $16 \%$ reduction in TOC, it significantly enhanced the biodegradability of nonylphenol ethoxylates by changing their molecular structure. In conclusion, removals of $70 \%$ and $62.5 \%$ were achieved for COD and TOC, respectively, by biodegradation after the ozonation process, whereas the reduction without ozonation was $25 \%$ for COD and $23 \%$ for TOC. This study showed that the optimum $\mathrm{pH}$ for the degradation of APEOs by 
ozone was 9. It seems that the ozone primarily attacked the polyethoxylate chain and not the aromatic ring.

Baig et al. [200] examined the matrix effect of wastewater during the ozonation of 4-t-OP and 4-iso-NP. The obtained data indicated that the wastewater matrix significantly affected the ozonation kinetics but did not change the related reactivity scale. The ozone dosage needed for full degradation of these substances increased, but a dose of $12 \mathrm{mg} \cdot \mathrm{L}^{-1}$ was enough for sufficient degradation. Ozonation was proven to be an effective solution to treat secondary wastewaters containing the abovementioned estrogenic active substances.

Zhang et al. [201] investigated the degradation of NP and 4tOP with ozone in aqueous solutions containing acetonitrile, to improve the solubility of NP and OP. The authors carried out experiments to test the effects of initial $\mathrm{pH}, \mathrm{AP}(\mathrm{NP}$ and $4 \mathrm{tOP}$ ) concentration, and ozone dosage on removal efficiency. Complete degradation of NP and OP was achieved after 6 min of ozonation at pH 9. Experiments at pH 6.5 showed that the amount of ozone needed for degradation was higher, whereby the degradation efficiency of NP was nearly $42 \%$ with an ozone dosage of $0.13 \mathrm{mg}$ ozone $\cdot \mathrm{min}^{-1}$, whereas, with almost threefold higher ozone dosage, the degradation efficiency increased to $96 \%$. It can be concluded that a higher initial AP concentration leads to a lower AP efficiency of degradation.

Nonylphenol (NP) is used as an antioxidant, as a plastic additive, and for synthesizing nonylphenol ethoxylates (NPEOs) as nonionic surfactants in detergents, emulsifying agents, pesticide formulations, herbicides, and dispersing agents in the paper industry. As NPEOs are degraded primarily to the corresponding nonylphenols [202], they are ubiquitous in the environment. They consist of a very complex mixture of isomers [194]. Nonylphenol belongs to the group of endocrine-disrupting chemicals causing neurological, immune, reproductive, and estrogenic effects. It has been shown to be toxic toward aquatic organisms and is capable of interfering with their regulatory systems and influencing their reproduction, development, and behavior. It can persist in the environment, especially soil, for a long duration because of its highly hydrophobic nature. Nonylphenol is incorporated into water matrices via agricultural runoff, wastewater effluents, agricultural sources, and groundwater leakage from the soil [203]. There is a lack of data in the literature on the impact of nonylphenols on human health. Thus, available results on research carried out on animals are emerging. The estrogenic effect of nonylphenol on humans will follow from these results. Remediation of nonylphenol is possible using physicochemical and microbiological methods [203]. Bacteria, such as Sphingomonas, Sphingobium, Pseudomonas, Pseudoxanthomonas, Thauera, Novosphingonium, Bacillus, Stenotrophomonas, Clostridium, Arthrobacter, Acidovorax, Maricurvus, Rhizobium, Corynebacterium, Rhodococcus, Burkholderia and Acinetobacter, fungi such as Aspergillus, Pleurotus, Trametes, Clavariopsis, Phanerochaete, Bjerkandera, Fusarium and Metarhizium, yeast Candida, and mold Mucor have been reported as efficient for the degradation of NP via their metabolic pathways. However, despite the significant importance of NP and its effects on the environment, there is still a lack of studies regarding this subject.

During the ozonation of industrial WW samples containing alkylphenols and their ethoxylates in an ozonation reactor with external recirculation of the reaction mixture, octylphenol ethoxylate (OPEO) and 4-nonyphenol (NP) were, with the exception of 4tOP, easily removed/transformed. The highest treatment efficiency was achieved for OPEO (88.1-98.2\%). The efficacy of NP was lower and showed greater variability (54.-86.3\%). The highest variability of treatment efficiency was measured for NPEO (3.-92.7\%) and was significantly affected by the variability of WW composition. The lowest treatment efficiencies (10.2-22.2\%) were measured for 4tOP [188].

Subsequent experiments were aimed at comparing the performance of ozonation and $\mathrm{O}_{3} / \mathrm{GAC}$ processes and were carried out in a mechanically stirred reactor. Mean values of treatment efficiencies in the range of 3.3\% (OPEO) to $83.2 \%(\mathrm{OP})$ were observed during ozonation of municipal WW after receiving an industrial WW with AP content. The highest removal efficiency of $92.7 \%$ was observed for nonylphenol ethoxylates. Similar removal rates of OP and their ethoxylates were published by Ning et al. [189,190] according 
to the results of single components (NP, NPEO). The most stable values of treatment efficiency were characteristic for $\mathrm{OP}(82.2-84.7 \%)$. The lowest and relatively stable values of treatment efficiency were typical for OPEO (0-6.5\%) and NP (10.4-17.0\%). Under the same conditions, no significant differences were observed in the removal of NP and NPEO by ozone alone and in combination with GAC. On the other hand, according to a comparison of these time dependencies, a higher removal/transformation rate of OPEO was achieved using the combined $\mathrm{O}_{3} /$ GAC process, which was twofold faster than ozonation. The other components were removed in the first $10 \mathrm{~min}$. The lowest toxicity impact of intermediates and products of ozonation treatment on Vibrio fisheri was measured after 10 min of ozonation, which was lower in comparison to the products of the $\mathrm{O}_{3} / \mathrm{GAC}$ process. After about $30 \mathrm{~min}$, a trend of a slight decrease in toxicity was observed for both processes [191].

In another series of experiments, industrial effluents containing alkylphenols were treated by ozonation, $\mathrm{O}_{3} / \mathrm{GAC}$, and ozonation processed combined with iron/manganese modified zeolites, i.e., $\mathrm{O}_{3} / \mathrm{ZEO}_{\mathrm{Fe}}$ and $\mathrm{O}_{3} / \mathrm{ZEO}_{\mathrm{Mn}}$ [192]. A comparison of the relative treatment efficiencies of pollution indicators by the studied processes related to $\mathrm{O}_{3} / G A C$ efficiencies is illustrated in Figure 5. The final treatment efficacy values for 4tOP, 4NP, $\mathrm{NPEO}, \mathrm{COD}$, and the DOC indicator by the $\mathrm{O}_{3} / \mathrm{GAC}$ treatment were $100 \%, 86 \%, 100 \%$, $66 \%$, and $83 \%$, respectively. As expected, the highest efficiencies of COD, TOC, and AP removal were observed for the $\mathrm{O}_{3} / \mathrm{GAC}$ process. The lowest removal efficiencies were observed for the Fenton reaction and ozonation [192].

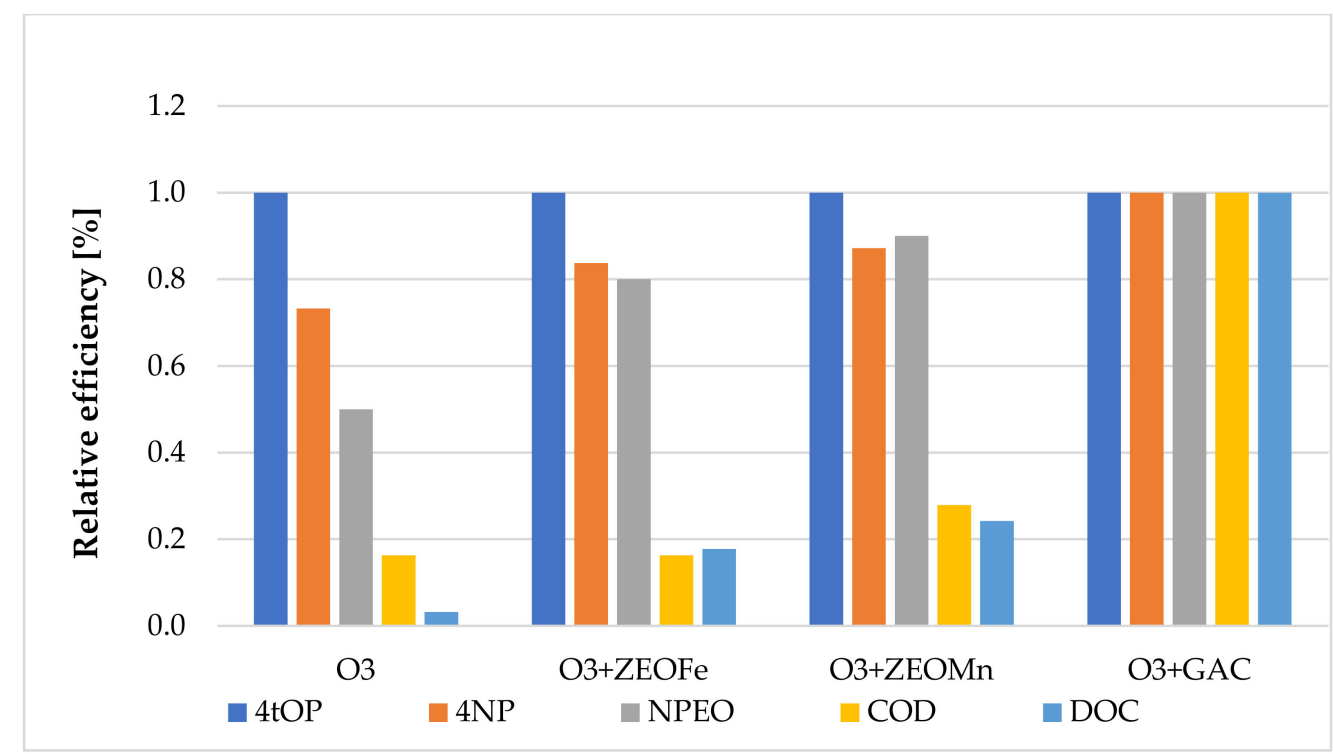

Figure 5. Relative efficiencies of several applied AOPs related to the $\mathrm{O}_{3} /$ GAC process [192].

Adsorptive ozonation with $\mathrm{O}_{3} / \mathrm{GAC}$ was the most efficient method and showed high potential for the practical use on the basis of not only the comparison of AP and APEO concentrations, as well as COD and TOC values, but also the ecotoxicity and cytotoxicity of the samples, as well as the respirometric measurements with activated sludge. Other studied methods also revealed a significant decrease in all examined pollution parameters. Adsorptive ozonation with $\mathrm{O}_{3} / \mathrm{ZEO}_{\mathrm{Mn}}$ was slightly more efficient than with $\mathrm{O}_{3} / \mathrm{ZEO}_{\mathrm{Fe}}$, but the difference between both processes and ozonation alone was not very high. All studied methods also led to a significant increase in the specific oxygen uptake rate of activated sludge microorganisms; therefore, an increase in the biodegradability of the wastewater could be assumed. The processes were efficient for the removal of the studied pollutants from wastewater and for the minimization of wastewater toxicity [193]. 


\subsection{BTEX}

In this subsection, the results presented in our papers [181-184] regarding the removal of BTEX substances from water and wastewater by ozonation, $\mathrm{O}_{3} / \mathrm{UV}, \mathrm{O}_{3} / \mathrm{H}_{2} \mathrm{O}_{2}$, and $\mathrm{O}_{3} / \mathrm{UV} / \mathrm{H}_{2} \mathrm{O}_{2}$ processes are reviewed.

BTEX substances constitute crude oil components benzene, toluene, ethylbenzene, and xylenes. These substances pose a serious threat to human health and the environment due to their toxicity, carcinogenicity, and mutagenicity. BTEX substances are often found in surface and underground water, resulting from industrial activities such as manipulation or storage of petroleum, leaching from storing units, or inappropriate waste(water) treatment methods. Treatments based on conventional WWTP processes have proven to be ineffective in oil compound elimination [204].

Despite the importance of oil for the world economy, the environmental problems related to oil production must always be well assessed, due to the composition of oil and its residues, which consist mainly of aromatic and aliphatic compounds. The toxicity of the aromatic fraction is higher than that of the aliphatic fraction. Aromatic compounds, including benzene, toluene, ethylbenzene, xylene isomers (BTEX), and phenols, are known to be more recalcitrant. Contamination from oil components can occur during the extraction process in sedimentation basins and as a result of storage tank leaks, including gasoline stations. Moreover, during its processing, a large volume of hydrocarbon-rich wastewater is generated, which, if left untreated, causes serious environmental impacts [205].

The spread of petroleum hydrocarbons affects the environment when leaked. In water, they form a thin coating on the surface, due to their hydrophobic nature [206]. These compounds usually occur at trace levels in superficial waters as a result of their volatility. However, they can be found in more elevated concentrations in groundwater, where they are considered the priority contaminants of such resources and, therefore, included as compounds to be evaluated in water analysis. The frequency of groundwater contamination with hydrocarbons, including BTEX, is increasing, demanding the development of more efficient methods to remove or minimize the damages caused by these compounds. Conventional physical treatments, in addition to high operational costs, remove the contaminants from the environment without destroying or transforming them, thereby producing an accumulation of toxic residues [207]. The application of biological processes is inadequate when the wastewater contains highly toxic refractory compounds, such as the aromatic fraction from dissolved organic compounds [205].

Petroleum substances can be a source of toxicity to the aquatic ecosystem [208]. The largest oil spills into surface and groundwater occur during oil extraction, as well as from tankers and vessels. Ozonation alone and ozonation in combination with other processes, i.e., $\left(\mathrm{O}_{3} / \mathrm{UV}, \mathrm{O}_{3} / \mathrm{H}_{2} \mathrm{O}_{2}, \mathrm{O}_{3} / \mathrm{UV} / \mathrm{H}_{2} \mathrm{O}_{2}\right)$, were investigated for the degradation of BTEX by Sumegová et al. [209]. The highest removal rates were observed during the first $5 \mathrm{~min}$ for all investigated pollutants. A longer ozonation time resulted in a very low increase in the efficiencies of studied processes. The removal efficiencies were similar for all investigated compounds. The removal efficiencies of BTEX components increased with the increase in reaction time. All BTEX components achieved removal efficiencies higher than $90 \%$ after $60 \mathrm{~min}$, with the exception of the $\mathrm{O}_{3} / \mathrm{H}_{2} \mathrm{O}_{2}$ process. This process achieved only $82 \%$ removal efficiency. The best fit of experimental degradation data of all studied pollutants was obtained using a second-order kinetic model. The results suggested that ozonation combined with UV radiation $\left(\mathrm{O}_{3} / \mathrm{UV}\right)$ is the most efficient process for the oxidation of BTEX. However, further experiments are required to improve process efficiency and to investigate the toxic impact of ozonation intermediates and products on aquatic microorganisms. Results obtained using ozone and the combined $\mathrm{O}_{3} / \mathrm{UV}$ process on model water containing BTEX components were reported by Derco et al. [210,211]. The highest removal rates were observed during the first $5 \mathrm{~min}$ of ozonation for all investigated pollutants. The highest removal efficiency (59.6\%) was achieved in the case of $p$-xylene. The lowest removal efficiency $(20 \%)$ in this reaction time was obtained for benzene. The removal efficiencies of BTX components increased with the reaction time. The removal 
efficiency of $p$-xylene reached $81.3 \%$ after $20 \mathrm{~min}$ of the process. The second highest removal efficiency $(72.2 \%)$ was observed for $o$-xylene. BTX presented removal efficiencies in the interval of $80.8 \%$ to $89.8 \%$ after $40 \mathrm{~min}$ of the ozonation process. In the case of $p$-xylene, $o$-xylene, toluene, and benzene, final removal efficiencies of $90 \%, 89.9 \%, 89.6 \%$, and $86.4 \%$, respectively, were observed. Insignificant differences in the removal rates and treatment efficiencies followed from the treatment of the investigated BTX compounds using $\mathrm{O}_{3}$ and $\mathrm{O}_{3} / \mathrm{UV}$. The best fit of experimental degradation data of all studied pollutants was obtained using a first-order kinetic model.

Results delineating the impact of $\mathrm{O}_{3}$ and $\mathrm{O}_{3} / \mathrm{UV}$ processes on a model sample of water contaminated with Natural 95 petrol were presented by Derco et al. [212]. Removal rates of the studied pollutants were comparable with those obtained by the $\mathrm{O}_{3}$ and $\mathrm{O}_{3} / \mathrm{UV}$ treatment. The removal efficiency of BTEX from wastewater contaminated by Natural 95 petrol ranged from $69.7 \%$ (ethylbenzene) to $95.5 \%$ (toluene) after $60 \mathrm{~min}$ of ozone treatment. Lower treatment efficiencies for the BTX model wastewater were observed during the first 5 min in comparison with the BTEX model wastewater. The reason for the lower removal efficiency in this experiment was the reaction of ozone with other organic petroleum compounds in the same conditions (in the presence of the same amount of $\mathrm{O}_{3}$ ). Better results were achieved with the $\mathrm{O}_{3} / \mathrm{UV}$ treatment. In the case of toluene, $p$-xylene, $m$-xylene, $o$-xylene, benzene, and ethylbenzene, final removal efficiencies of $95.9 \%, 94.9 \%, 91.1 \%$, $84.0 \%$, and $95 \%$, respectively, were observed after $60 \mathrm{~min}$ of $\mathrm{O}_{3} / \mathrm{UV}$ treatment.

\subsection{Organochlorinated Pesticides}

In this subsection, results regarding the removal of organochlorinated pesticides from water and wastewater by ozonation, $\mathrm{O}_{3} / \mathrm{UV}, \mathrm{O}_{3} / \mathrm{H}_{2} \mathrm{O}_{2}, \mathrm{O}_{3} / \mathrm{GAC}, \mathrm{O}_{3} / \mathrm{ZEO}$, and $\mathrm{O}_{3} / \mathrm{nZVI}$ processes are reviewed $[177,188,213-216]$.

Organochlorine substances are characterized by their high adsorption and bonding affinity to fats and their persistence in the environment. They are mainly used as pesticides, known to be chemically very stable and toxic compounds which are characterized by high bioaccumulation. They accumulate mainly in the adipose tissue, liver, kidney, muscle, brain, and heart [50].

Some organochlorine substances may be produced in other productions or are used as raw materials in the manufacture of other products. For example, sources of hexachlorobenzene include the production of pentachlorobenzene (PCB) carbon tetrachloride, perchlorethylene and trichlorethylene. It can occur in waste incineration, as well as in the paper and engineering industries. It is used in the production of plasticizers to produce cellulose esters, vulcanization accelerators, and flame retardants. Hexachlorobutadiene (HCBD) is used to make rubber compounds as a solvent or as a heat transfer or hydraulic fluid. It also arises as a byproduct, e.g., wastes from perchlorethylene and carbon tetrachloride production by perchlorination. It has been used and is still used in some countries in the manufacture of lubricants and as a pesticide in agriculture. It is formed as a byproduct in the industrial production of some chlorinated hydrocarbons. It can be formed in landfills during the decomposition processes of chlorine-containing waste and, to a lesser extent, during waste incineration. PCB can be formed in the production of tri- and tetrachlorethylene. It can occur in WW from oil refineries, ironworks, steel mills, pulp and paper mills, landfills, and WWTPs. It can also be released into the environment through substances that contain PCB as an admixture (e.g., the insecticide pentachloronitrobenzene, hexachlorobenzene (HCB), or some chlorinated solvents). It is also formed during the natural degradation of hexachlorobenzene and lindane. Hexachlorobenzene is used in the production of lindane [217].

Ikelhata and El-Din $[129,218]$ investigated the degradation of four main groups of pesticides by ozone-based AOPs, namely, carbamates, chlorophenoxy compounds, organochlorines, and organophosphates. They discussed the degree of pesticide degradation, reaction kinetics, identity and properties of degradation byproducts and intermediates, and possible degradation pathways. 
The removal of pesticides from industrial wastewater is an important process because of their bioresistant, bioccumulative, carcinogenic, and mutagenic nature. Suitable methods for the transformation of pesticides in aquatic environments are ozonation and ozone-based oxidation processes such as $\mathrm{O}_{3} / \mathrm{H}_{2} \mathrm{O}_{2}, \mathrm{O}_{3} / \mathrm{UV}$, and $\mathrm{O}_{3} / \mathrm{H}_{2} \mathrm{O}_{2} / \mathrm{UV}$ [218].

Pesticides also form the largest group of chemicals with the same action in the list of priority substances. Directive 2013/39/EU [6] includes the following pesticides in addition to PHS and PS: aldrin, dichlorodiphenyl-trichloroethane, dicofol, dieldrin, endrin, endosulfan, isodrin, heptachlor, hexachlorocyclohexane (lindane), hexachlorobutadiene, pentachlorobenzofosphen, pentachlorobenzene, pentachlorobenzene, dichlorvos, atrazine, simazine, terbutrin, diuron, isoproturon, trifluralin, cypermethrin, alachlor, DDT, cybutrin, quinoxyfen, aclonifen, and bifenox [6,7].

The preferred processes for their removal from wastewaters are adsorption, stripping, and membrane processes $[219,220]$. The degradation processes are dominated by photolysis, hydrolysis, chemical oxidation, dehalogenation processes, and biodegradation [53].

Adsorption to activated carbon allows the removal of many micropollutants. However, to reach equilibrium concentration for many substances, up to several hours of reaction is needed. In addition, adsorption on activated carbon is not applicable to polar substances. Compared to the degradation process ozonation, adsorption is a much slower process. Adsorption on activated carbon is relatively less energy demanding. However, the production of AC is relatively energy-intensive. Energy consumption in the production of activated carbon is higher compared to the operating costs of the ozonation process [75]. Neither of the above processes is able to completely remove organochlorine substances. Physical processes only separate the pollutants into another phase, and further processing is required for the adsorbed pesticides. Chemical oxidation leads to incomplete decomposition of pesticide molecules and, consequently, to the formation of harmful byproducts. Therefore, a combination of physical, chemical, and biological processes is usually used to remove pesticide residues and byproducts in water treatment $[9,22,24,88]$. Felsot et al. [221] proposed a combination of physical and chemical methods with biological processes as a suitable and acceptable option for the treatment of pesticide-containing effluents. Feakin et al. [222] recommended the application of biodegradation processes combined with adsorption on granular activated carbon. Reynolds et al. and Camel et al. [46,223] reported chemical oxidation, e.g., ozonation and AOPs, whereas Hollender et al. [75,94] reported ozonation in combination with detoxification on a slow sand filter or on granular coal.

Wei et al. [224] presented the results of a study aimed at removing hexachlorobenzene (HCB) in water using advanced $\mathrm{UV}, \mathrm{O}_{3}$, and $\mathrm{UV} / \mathrm{O}_{3}$ oxidation processes. The results showed that UV radiation itself does not contribute to the removal of HCB. HCB is better degraded by $\mathrm{O}_{3}$ and a combination of $\mathrm{UV} / \mathrm{O}_{3}$. During ozonation and the combination of $\mathrm{UV} / \mathrm{O}_{3}$, a higher $\mathrm{HCB}$ removal efficiency was achieved. After $40 \mathrm{~min}, \mathrm{a} 50 \% \mathrm{HCB}$ removal efficiency with an initial concentration of $0.2 \mathrm{mg} \cdot \mathrm{L}^{-1}$ was achieved at $\mathrm{pH}=3$. The rate of $\mathrm{HCB}$ removal during ozonation and the combination of $\mathrm{UV} / \mathrm{O}_{3}$ was described by pseudo-first-order kinetics.

Scientific data published during the period 2007-2018 concerning the development, optimization, and application of different types of AOPs used for the degradation of 15 priority synthetic pesticides included in the European policy in the water field defined by Directive 2013/39/EU were summarized by Vagi and Petsas [225].

The abovementioned article five selected organochlorine pesticides (HCBD, PCB, $\mathrm{HCB}, \mathrm{LIN}$, and HC) as organic contaminants of a model wastewater. The results of their examination of the ozonation, $\mathrm{O}_{3} / \mathrm{UV}$, adsorptive ozonation, and combined ozone with zero-valent iron nanoparticle (nZVI) and zeolite (ZEO) processes are presented below.

Ozonation and the combination of ozone and UV treatment processes were studied [226]. The highest removal rate was observed for heptachlor using $\mathrm{O}_{3} / \mathrm{UV}$ combination. In this case, 55\% efficiency removal was measured after $10 \mathrm{~min}$ of ozonation, while $80 \%$ treatment efficiency was observed during the same reaction time when applying the $\mathrm{O}_{3} / \mathrm{UV}$ process. Almost total removal of heptachlor was observed after $40 \mathrm{~min}$ of ozonation. On the 
other hand, very close treatment efficiency was observed when using the $\mathrm{O}_{3} / \mathrm{UV}$ process. The second highest removal efficiency was observed for hexachlorobutadiene. Ozonation was more efficient in this case, where $65 \%$ removal efficiency was measured after $10 \mathrm{~min}$ of ozonation, while only $40 \%$ treatment efficiency was observed with the combined $\mathrm{O}_{3} / \mathrm{UV}$ process during the same reaction time. In the case of pentachlorobenzene, final removal efficiencies $80 \%$ and $40 \%$ were observed after $40 \mathrm{~min}$ of ozonation and combined $\mathrm{O}_{3} / \mathrm{UV}$ processes, respectively. The lowest removal rates were observed for hexachlorobenzene with $75 \%$ efficiency removal after $40 \mathrm{~min}$ of ozonation. The best fit of the experimental degradation data of all studied pollutants was obtained using a second-order kinetic model. It can be concluded that, with the exception of $\mathrm{HC}$, ozonation is a promising procedure for the removal of investigated pollutants from aquatic environments [210]. The highest removal rates of investigated organochlorine pesticides were observed during the first 5 min of ozonation for all investigated pollutants. The highest removal efficiency $(74.5 \%)$ was achieved in the case of HCBD. The lowest removal efficiency (30\%) was obtained for HC during this reaction time. The removal efficiencies of studied chlorinated pollutants increased with the increase in reaction time, with the exception of HC. The removal efficiency of HCBD reached $87 \%$ after $20 \mathrm{~min}$ of the process. The second highest removal efficiency (73.4\%) was observed for PCB. HCBD also reached the highest removal efficiency $(90.7 \%)$ after 60 min of ozonation. In the cases of PCB, LIN, and HCB, final removal efficiencies of $85.2 \%, 80.7 \%$, and $70.2 \%$, respectively, were observed. Higher removal rates were observed with $\mathrm{O}_{3} / \mathrm{UV}$ treatment. The best fit of the experimental degradation data of all studied pollutants was obtained using second-order kinetics. The highest adsorption affinity was measured for GAC, LIN, HCBD, and PCB. On the other hand, zeolite and excess activated sludge manifested relatively high affinity to $\mathrm{PCB}$ and heptachlor $\mathrm{HC}$. The highest values of specific removal rate were observed when combined $\mathrm{O}_{3} / \mathrm{GAC}$ processes were applied, particularly for HCB, PCB, and HC [213].

The adsorption affinity of activated carbon (GAC), zeolite (ZEO), and activated sludge to the studied organochlorine priority substances was also studied [227]. The highest removal efficiency was achieved during $0.5 \mathrm{~h}$ sorption on activated sludge with maximum removal efficiencies of $99.1 \%$ for $\mathrm{HC}$ and $98.8 \%$ for $\mathrm{HCB}$. In the cases of $\mathrm{HCBD}, \mathrm{PCB}$, and LIN, the observed maximal treatment efficiencies were $98.1 \%, 95.3 \%$, and $57.6 \%$, respectively. In the case of ZEO adsorbent, a maximum removal efficiency of $93.8 \%$ over $0.5 \mathrm{~h}$ was achieved for $\mathrm{HCB}$, while the corresponding values were $92.1 \%, 83.7 \%, 72.9 \%$, and $25.8 \%$ for HC, HCBD, PCB, and LIN, respectively. Using GAC adsorbent, the following adsorption efficiencies were obtained over $3 \mathrm{~h}$ contact time: $64.5 \%$ for HCBD, $60.5 \%$ for $\mathrm{HCH}, 59.9 \%$ for $\mathrm{HCB}, 57.0 \%$ PCB, and $56 \%$ for LIN [227].

Our study also focused on research aimed at the potential of the integrated $\mathrm{O}_{3} / \mathrm{nZVI}$ process for improving the removal of selected specific synthetic substances from water $[214,215,227]$. Five organochlorine pesticides, i.e., hexachlorobutadiene (HCBD), pentachlorobenzene (PCB), hexachlorobenzene (HCB), lindane (LIN), and heptachlor (HC), in water were investigated. Efficiency and removal rates by the integrated ozonation and nZVI $\left(\mathrm{O}_{3} / \mathrm{nZVI}\right)$ process were evaluated. The effect of ozonation and nZVI treatments on the same components was also determined and used as a reference for comparison. The results illustrated the potential of the integrated oxidation/reductive $\mathrm{O}_{3} /$ nZVI process for the removal of the investigated pesticides, listed by the Stockholm Convention as persistent organic pollutants in water and wastewater. The commercial suspension of Nanofer nZVI particles showed very promising efficiencies for the removal of all studied organochlorine pesticides. With the exception of PCB $(81.0 \%)$, removal efficiencies of more than $94 \%$ were observed after $30 \mathrm{~min}$ of the process. The highest performance of this treatment process was represented by the $99.9 \%$ efficiency of LIN removal, which is usually very problematic even with AOPs. Ozonation alone after $3 \mathrm{~min}$ of the process showed removal efficiencies over $92 \%$ for all studied pesticides, with the exception of LIN and PCB $(67.5 \%$ and $9.3 \%$ removal efficiencies after 15 min of ozonation, respectively). Integrated $\mathrm{O}_{3} / \mathrm{nZVI}$ resulted in an improvement in removal efficiencies for the majority of pollutants in comparison 
to ozone alone. The process effectiveness was based on a comparison of second-order kinetic constants used for the rate of process evaluation. The corresponding values using the $\mathrm{O}_{3} / \mathrm{nZVI}$ integrated process were two orders higher for HCBD in comparison with the nZVI process and one order higher for $\mathrm{PCB}, \mathrm{HCB}, \mathrm{HC}$, and LIN in comparison with the ozonation process. It can be concluded that the integrated $\mathrm{O}_{3} / \mathrm{nZVI}$ process is a promising procedure for the removal of investigated pollutants from aquatic environments. This study showed the great potential of this integrated process for the removal/degradation of pesticides, and it needs to be further developed, especially for the investigation of the impact of products/intermediates on aquatic life [216].

Results following an investigation of the ozonation, $\mathrm{O}_{3} / \mathrm{UV}$, adsorptive ozonation, and combined ozone with zero-valent iron nanoparticle (nZVI) and zeolite (ZEO) processes were presented in the work of Derco et al. [215]. Five selected organochlorine pesticides, i.e., hexachlorobutadiene (HCBD), pentachlorobenzene (PCB), hexachlorobenzene (HCB), lindane (LIN), and heptachlor (HC), in water were investigated. Three of these are specified as priority hazardous substances, while four of the pesticides are listed by the Stockholm Convention as persistent organic pollutants. Process removal efficiency exceeding $92 \%$ for all studied pesticides after 3 min of ozonation was achieved, with PCB (50.8\% removal efficiency) and LIN (no removal) being the only exceptions. Slightly higher removal rates and efficiencies were measured when using the $\mathrm{O}_{3} / \mathrm{UV}$ process. However, the problem regarding the low removal efficiencies of LIN and $\mathrm{HCBD}$ also remained unsolved when using this process. The adsorptive $\mathrm{O}_{3} / \mathrm{GAC}$ and $\mathrm{O}_{3} / \mathrm{ZEO}$ ozonation processes provided high removal rates and efficiencies for all pollutants, again except for LIN. A significant reduction in reaction time resulted from these processes in comparison to $\mathrm{O}_{3}$ or $\mathrm{O}_{3} / \mathrm{UV}$ processes. High removal efficiencies were measured for LIN, PCB, and $\mathrm{HC}$ within about 5 min with nZVI. The highest differences were observed for the combined $\mathrm{GAC} / \mathrm{O}_{3}$ process in comparison with adsorption on GAC [215].

In a paper by Derco at al. [214], results of ozonation, adsorptive ozonation, and combined ozone with zero-valent iron nanoparticle processes were presented. Five selected organochlorine pesticides were used as organic contaminants of model water. High removal efficiencies were observed using the ozonation process (over $90 \%$ after $60 \mathrm{~min}$ ), except for LIN and HCBD. The highest removal rates and efficiencies were measured using the $\mathrm{O}_{3} / \mathrm{UV}$ process. However, the problem of low removal efficiencies for LIN and HCBD remained unsolved for this process. Adsorptive $\mathrm{O}_{3} / \mathrm{GAC}$ and $\mathrm{O}_{3} / \mathrm{ZEO}$ ozone-based processes provided high removal rates and efficiencies for all pollutants, except for LIN. A significant reduction in reaction time for these processes, compared to the $\mathrm{O}_{3}$ or $\mathrm{O}_{3} / \mathrm{UV}$ systems, was also observed. High removal efficiencies were measured for LIN, PCB, and $\mathrm{HC}$ within about $5 \mathrm{~min}$ of the nZVI process. However, very low removal efficiencies were observed for HCBD and HCB with this process under the same reaction conditions. Moreover, the $\mathrm{O}_{3} /$ nZVI process was characterized by a significant reduction of the reaction time when compared with the ozonation processes. The results suggest that nZVI and $\mathrm{O}_{3} /$ nZVI processes have the highest potential to intensify the degradation and removal of organochlorine pollutants [214].

\section{Conclusions}

The aim of this review article was to present up-to-date trends in the research and application of ozone-based processes for the removal of micropollutants from wastewater. Priority substances, micropollutants, and emerging pollutants, as well as processes and technologies for their transformation and elimination with a focus on ozonation and advanced ozone-based oxidation processes, were briefly specified. Ozone-based processes appear to be an efficient and promising technology for removing micropollutants from water and wastewater. Various substances could be removed with high efficiency and reaction rate.

Ozonation and ozone-based processes show their treatment potential mainly when applied as part of tertiary wastewater treatment. The advantage of ozonation is that it can 
lead to complete mineralization of organic substances or to transformation into more polar compounds, thus resulting in increased efficiency of biological treatment. Ozonation of excess sludge also increases the removal of micropollutants absorbed into the sludge.

For ozone-resistant compounds, advanced ozone-based oxidation processes, e.g., $\mathrm{O}_{3} / \mathrm{H}_{2} \mathrm{O}_{2}$ or $\mathrm{O}_{3} / \mathrm{UV}$, can be used for the oxidation. The combined $\mathrm{O}_{3} / \mathrm{GAC}$ and $\mathrm{O}_{3} /$ zeolite processes show high intensification potential. This literature review revealed the potential of nanocatalysts in advanced ozone-based oxidation processes for the removal of micropollutants. The application of metal nanoparticles, metal oxide nanoparticles, carbon nanotubes of nanocomposites, and nanoxide metals attached to membranes represents a huge potential in the field of water and wastewater treatment.

In AOPs, much of the oxidative capacity is lost due to the wastewater matrix and hydroxyl radical scavengers. The preferred application of ozone-based processes is water treatment due to the low content of organic substances. Ozonation and ozone-based AOPs are promising tertiary technologies to significantly reduce the toxicity and micropollutant emissions of wastewater. However, the overall benefits of ozone-based processes should be assessed, including the impact of degradation products on the aquatic environment.

The review also focused on selected alkylphenols, petroleum substances, and organochlorine pesticides. The selectivity of ozone for the removal of alkylphenols and their ethoxylates depends on the type and composition of the wastewater. During the ozonation of real industrial wastewater discharged into the municipal sewerage system, high values of NP and NPEO removal efficiency were measured. During the ozonation of municipal wastewater from the outlet of the biological stage of the WWTP, low efficiency was observed for alkylphenols and their ethoxylates, as well as 4tOP. When using the $\mathrm{O}_{3} / \mathrm{GAC}$ process, no significant differences were observed in the removal of NP and NPEO compared to ozonation alone. However, for OPEO, a faster removal rate and a significantly faster onset of the removal process were measured.

The $\mathrm{O}_{3}$ and $\mathrm{O}_{3} / \mathrm{UV}$ processes enable high efficiency in removing BTX/BTEX components from the aqueous environment. In the case of model samples containing Natural 95 petrol, lower removal rates and efficiencies were measured compared to BTEX model water, in addition to higher initial speeds, as well as overall removal efficiency.

Ozone showed the highest affinity for HCBD, HC, and HCB. The lowest removal rate was observed for LIN. There were no significant changes in concentration after this time. It can be concluded that, in addition to $\mathrm{HC}$, ozonation is a promising procedure for the removal of investigated pollutants from the aquatic environment.

With regard to organochlorine substances, the potential for intensification of the combined adsorption ozonation $\left(\mathrm{O}_{3} / \mathrm{GAC}\right)$ process is considerable compared to ozone alone. The comparison of processes with nZVI (iron nanoparticles), $\mathrm{O}_{3}$, and $\mathrm{O}_{3} / \mathrm{nZVI}$ revealed higher reaction rates of iron nanoparticles compared to other processes, with significant selective affinity for LIN in particular. Higher values of reaction rates were recorded for $\mathrm{O}_{3} / \mathrm{nZVI}$ compared to ozonation alone, indicating the catalytic effect of iron oxides and other components of nZVI particles. In this context, however, it is necessary to mention the relatively high costs associated with the price of this reactant.

The results of our research show the possibility of using an integrated process of transformation/degradation of alkylphenols adsorbed onto activated sludge, which increases the biodegradability of sludge and biogas production following ozone application.

Author Contributions: Conceptualization, J.D. (Ján Derco), A.Ž.G., and J.D. (Jozef Dudáš); methodology, J.D. (Ján Derco), A.Ž.G., and J.D. (Jozef Dudáš); software, O.Č.; validation, J.D. (Ján Derco), A.Ž.G., and O.Č.; formal analysis, J.D. (Ján Derco), A.Ž.G., O.Č., and J.D. (Jozef Dudáš); investigation, J.D. (Jozef Dudáš), O.Č., L.S., and K.Š.; resources, J.D. (Ján Derco); data curation, J.D. (Ján Derco); writing —original draft preparation, J.D. (Ján Derco), A.Ž.G., O.Č., and J.D. (Jozef Dudáš); writingreview and editing, J.D. (Ján Derco), A.Ž.G., and J.D. (Jozef Dudáš); visualization, O.Č. and J.D. (Ján Derco); supervision, J.D. (Ján Derco); project administration, J.D. (Ján Derco); funding acquisition, J.D. (Ján Derco) and A.Ž.G. All authors have read and agreed to the published version of the manuscript. 
Funding: This work was supported by the Slovak Research and Development (SRDA) under contract no. APVV-0656-12 and Slovenian Research Agency ARRS (Research Program Chemical Engineering P2-0191).

Acknowledgments: The work was partially accomplished in the framework of the National Scholarship Program of the Slovak Republic for a scholarship stay of A.Ž.G. in Slovakia (ID 29291 (2020) and ID 25614 (2019), SAIA).

Conflicts of Interest: The authors declare no conflict of interest.

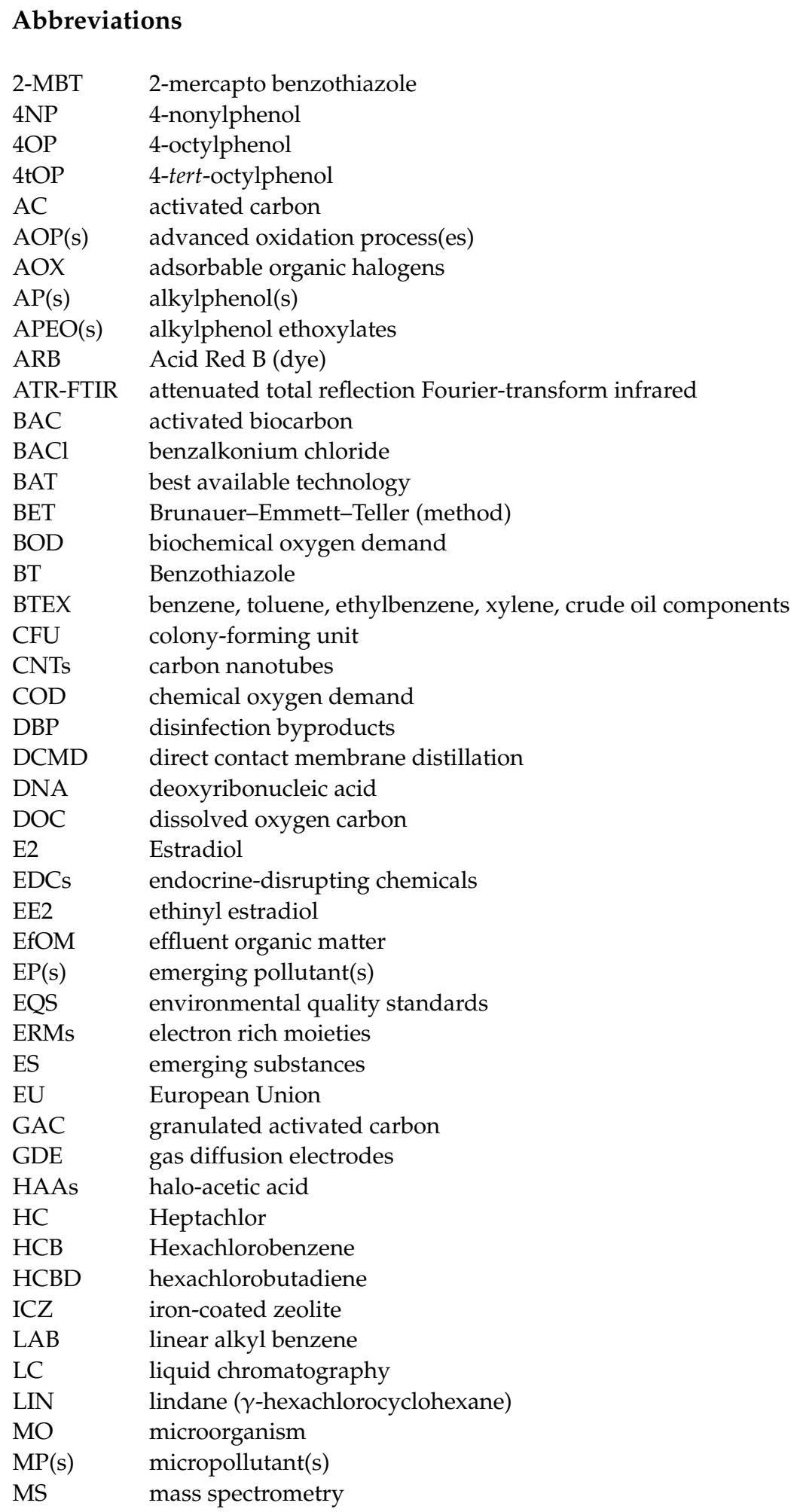




$\begin{array}{ll}\text { NDMA } & \text { N-nitrosodimethylamine } \\ \text { NPEO(s) } & \text { nonylphenol ethoxylate(s) } \\ \text { NP } & \text { 4-nonylphenol } \\ \text { NPs } & \text { nanoparticles } \\ \text { nZVI } & \text { nano zero-valent iron } \\ \text { OG } & \text { Orange-G (dye) } \\ \text { OPEO } & \text { octylphenol ethoxylate } \\ \text { OZCO } & \text { ozone catalytic oxidation } \\ \text { PAH } & \text { polycyclic aromatic hydrocarbons } \\ \text { PCB } & \text { pentachlorobenzene } \\ \text { p-CBA } & \text { p-chlorobenzoic acid } \\ \text { PE } & \text { population equivalent } \\ \text { PHS } & \text { priority hazardous substances } \\ \text { PS } & \text { priority substances } \\ \text { QFM } & \text { Quench Flow Module } \\ \text { RB 19 } & \text { Reactive Blue 19 (dye) } \\ \text { RNA } & \text { ribonucleic acid } \\ \text { SS } & \text { suspended solids } \\ \text { SSF } & \text { slow sand filtration } \\ \text { SUVA } & \text { specific ultraviolet absorbance } \\ \text { TCC } & \text { total cell counts } \\ \text { TEQ } & \text { toxic equivalent concentrations } \\ \text { TF } & \text { trickling filtration } \\ \text { TOBr } & \text { total organic bromine } \\ \text { TOC } & \text { total organic carbon } \\ \text { US } & \text { ultrasonic } \\ \text { UV } & \text { ultraviolet } \\ \text { WFD } & \text { Water Framework Directive } \\ \text { WW } & \text { wastewater } \\ \text { WWTP } & \text { wastewater treatment plant } \\ \text { XPS } & \text { X-ray photoelectron spectroscopy } \\ \text { ZEO } & \text { zeolite(s) } \\ \text { ZEOFe } & \text { iron-modified zeolite } \\ \text { ZEOMn } & \text { manganese-modified zeolite } \\ & \end{array}$

\section{References}

1. Baronti, C.; Curini, R.; D’Ascenzo, G.; Di Corcia, A.; Gentili, A.; Samperi, R. Monitoring natural and synthetic estrogens at activated sludge sewage treatment plants and in a receiving river water. Environ. Sci. Technol. 2000, 34, 5059-5066. [CrossRef]

2. Barbosa, M.O.; Moreira, N.F.F.; Ribeiro, A.R.; Pereira, M.F.R.; Silva, A.M.T. Occurrence and removal of organic micropollutants: An overview of the watch list of EU Decision 2015/495. Water Res. 2016, 94, 257-279. [CrossRef]

3. Ribeiro, A.R.; Pedrosa, A.; Moreira, N.F.R.; Pereira, M.F.R.; Silva, A.M.T. Environmental friendly method for urban wastewater monitoring of micropollutants defined in the Directive 2013/39/EU and Decision 2015/495/EU. J. Chromatogr. A 2015, 1418, 140-146. [CrossRef]

4. European Parliament, Council of the European Union. Directive 2000/60/EC of the European Parliament and of the Council of 23 October 2000 establishing a framework for com-munity action in the field of water policy. Off. J. Eur. Communities 2020, 327, 1-73.

5. European Parliament, Council of the European Union. Decision No. 2455/2001/EC of the European Parliament and of the Council establishing the list of priority substances in the field of water policy and amending Directive 2000/60/EC. Off. J. Eur. Union 2001, 331, 1-5.

6. European Parliament, Council of the European Union. Directive 2013/39/EU of the European Parliament and of the Council of 12 August 2013 amending Directives 2000/60/EC and 2008/105/EC as regards priority substances in the field of water policy. Off. J. Eur. Union 2013, 226, 1-17.

7. Ribeiro, A.R.; Nunes, O.C.; Pereira, M.F.R.; Silva, A.M.T. An overview on the advanced oxidation processes applied for the treatment of water pollutants defined in the recently launched Directive 2013/39/EU. Review. Environ. Int. 2015, 75, 33-51. [CrossRef] [PubMed]

8. European Action on Hazardous Substances, Micropollutants and Pharmaceuticals in Water. Available online: https://www. aquastrategy.com/article/european-action-hazardous-substances-micropollutants-and-pharmaceuticals-water (accessed on 23 February 2006).

9. Fuerhacker, M. EU Water Framework Directive and Stockholm Convection. Can we reach the targets for priority substances and persistent organic pollutants? Environ. Sci. Pollut. Res. 2009, 16, 92-97. [CrossRef] 
10. United Nations Environment Program. Stockholm Convention Stockholm Convention on Persistent Organic Pollutants; United Nations Environment Program: Stockholm, Sweden, 2001.

11. Stockholm Convention. Governments Unite to Step-Up Reduction on Global DDT Reliance and Add Nine New Chemicals under International Treaty; United Nations Environment Program: Geneva, Switzerland, 2009.

12. Luo, Y.; Guo, W.; Ngo, H.H.; Nghiem, L.D.; Hai, F.I.; Zhang, J.; Liang, S.; Wang, X.C. A review on the occurrence of micropollutants in the aquatic environment and their fate and removal during wastewater treatment. Sci. Total Environ. 2014, 473-474, 619-641. [CrossRef] [PubMed]

13. Bourgin, M.; Beck, B.; Boehler, M.; Borowska, E.; Fleiner, J.; Salhi, E.; Teichler, R.; von Gunten, U.; Siegrist, H.; McArdell, C.S. Evaluation of a full-scale wastewater treatment plant upgraded with ozonation and biological post-treatments: Abatement of micropollutants, formation of transformation products and oxidation by-products. Water Res. 2018, 129, 486-498. [CrossRef]

14. The Swedish Environmental Protection Agency. Advanced Wastewater Treatment for Separation and Removal of Pharmaceutical Residues and Other Hazardous Substances: Needs, Technologies, and Impacts; Naturvårdsverket: Stockholm, Sweden, 2018; ISSN 0282-7298, ISBN 978-91-620-6803-5.

15. Chu, L.; Wang, J.; Wang, B.; Xing, X.-H.; Yan, S.; Sun, X.; Jurick, B. Changes in biomass activity and characteristics of activated sludge exposed to low ozone dose. Chemosphere 2009, 77, 269-272. [CrossRef] [PubMed]

16. Geissen, V.; Mol, H.; Klumpp, E.; Umlauf, G.; Nadal, M.; van der Ploeg, M.; van de Zee, S.E.A.T.M.; Ritsema, C.J. Emerging pollutants in the environment: A challenge for water resource management. Int. Soil Water Conserv. Res. 2015, 3, 57-65. [CrossRef]

17. Heberer, T. Occurrence, fate, and removal of pharmaceutical residues in the aquatic environment: A review of recent research data. Toxicol. Lett. 2002, 131, 5-17. [CrossRef]

18. Norman. Network of Reference Laboratories, Research Centers and Related Organizations for Monitoring of Emerging Environmental Substances. Available online: http:/ / www.norman-network.net (accessed on 25 February 2019).

19. Das, S.; Ray, N.M.; Wan, J.; Khan, A.; Chakraborty, T.; Ray, M.B. Micropollutants in Wastewater: Fate and removal processes. In Physico-Chemical Wastewater Treatment and Resource Recovery; InTech: London, UK, 2017; pp. 74-107. [CrossRef]

20. Hollender, J.; Zimmermann, S.G.; Koepke, S.; Krauss, M.; McArdell, C.S.; Ort, C.; Singer, H.; Gunten, U.V.; Siegrist, H. Elimination of organic micropollutants in a municipal wastewater treatment plant upgraded with a full-scale post-ozonation followed by sand filtration. Environ. Sci. Technol. 2009, 43, 7862-7869. [CrossRef] [PubMed]

21. Ternes, T.A. Occurrence of drugs in German sewage treatment plants and rivers. Water Res. 1998, 32, 3245-3260. [CrossRef]

22. Fromme, H.; Küchler, T.; Otto, T.; Pilz, K.; Müller, J.; Wenzel, A. Occurrence of phthalates and bisphenol A and F in the environment. Water Res. 2002, 36, 1429-1438. [CrossRef]

23. Kreuzinger, N. (Ed.) Occurrence of highly discussed pollutants in the stretch of the Austrian Danube related to the Catchment Area. In Proceedings of the SETAC Europe 12th Annual Meeting, Vienna, Austria, 12-16 May 2002.

24. Eggen, R.I.; Hollender, J.; Joss, A.; Schärer, M.; Stamm, C. Reducing the discharge of micropollutants in the aquatic environment: The benefits of upgrading wastewater treatment plants. Environ. Sci. Technol. 2014, 48, 7683-7689. [CrossRef]

25. Schüth, P.D.C. Demonstrating Managed Aquifer Recharge as a Solution to Water Scarcity and Drought: An EU FP7 Project. Available online: http:/ / www.marsol.eu/files/marsol_d14-1_list-ofmicropollutants (accessed on 17 January 2021).

26. Gerly, H. Relevant Studies Related to the Presence of Micropollutants in the Environment 18 May 2016. Available online: http:/ / micropollutants.com/About-micropollutants (accessed on 14 May 2020).

27. Gottschalk, C.; Libra, J.; Saupe, A. Ozonation of Water and Waste Water: A Practical Guide to Understanding Ozone and Its Application; Wiley-VCH: Weinheim, Germany, 2000; ISBN 9783527301782. [CrossRef]

28. Alvares, A.B.C.; Diaper, C.; Parsons, S.A. Partial Oxidation by Ozone to Remove Recalcitrance from Wastewaters-A Review. Environ. Technol. 2001, 22, 409-427. [CrossRef] [PubMed]

29. Poyatos, J.M.; Muñio, M.M.; Almecija, M.C.; Torres, J.C.; Hontoria, E.; Osorio, F. Advanced Oxidation Processes for Wastewater Treatment: State of the Art. Water Air Soil Pollut. 2010, 205, 187. [CrossRef]

30. Hussain, M.; Mahtab, M.S.; Farooqi, I.H. The applications of ozone-based advanced oxidation processes for wastewater treatment: A review. Adv. Environ. Res. 2020, 9, 191-214. [CrossRef]

31. Parsons, S. Advanced Oxidation Processes for Water and Wastewater Treatment; IWA Publishing: London, UK, 2004 ; ISBN 1843390175.

32. Hoigné, J.; Bader, H. Rate constants of reactions of ozone with organic and inorganic compounds in water-I. Non-Dissociating organic compounds. Water Res. 1983, 17, 173-183. [CrossRef]

33. Hoigné, J.; Bader, H. Rate constants of reactions of ozone with organic and inorganic compounds in water-II. Dissociating organic compounds. Water Res. 1983, 17, 185-194. [CrossRef]

34. Hoigné, J.; Bader, H. Rate constants of reactions of ozone with organic and inorganic compounds in water-III. Inorganic compounds and radicals. Water Res. 1985, 19, 993-1004. [CrossRef]

35. Ahn, K.-H.; Yeom, I.T.; Park, K.Y.; Maeng, S.K.; Lee, Y.; Song, K.-G.; Hwang, J.H. Reduction of sludge by ozone treatment and production of carbon source for denitrification. Water Sci. Technol. 2002, 46, 121-125. [CrossRef] [PubMed]

36. Lee, J.W.; Cha, H.-Y.; Park, K.Y.; Song, K.-G.; Ahn, K.-H. Operational strategies for an activated sludge process in conjunction with ozone oxidation for zero excess sludge production during winter season. Water Res. 2005, 39, 1199-1204. [CrossRef] [PubMed]

37. Lee, Y.; von Gunten, U. Oxidative transformation of micropollutants during municipal wastewater treatment: Comparison of kinetic aspects of selective (chlorine, chlorine dioxide, ferrate VI, and ozone) and non-selective oxidants (hydroxyl radical). Water Res. 2010, 44, 555-566. [CrossRef] [PubMed] 
38. Qiang, Z.; Nie, Y.; Ben, W.; Qu, J.H.; Zhang, H.Q. Degradation of endocrine-disrupting chemicals during activated sludge process. Water Res. 2013, 41, 2341-2348. [CrossRef]

39. Da Silva, L.M.; Jardim, W.F. Trends and strategies of ozone application in environmental problems. Química Nova 2006, 29, 310-317. [CrossRef]

40. Sánchez-Polo, M.; von Gunten, U.; Rivera-Utrilla, J. Efficiency of activated carbon to transform ozone into 'OH radicals: Influence of operational parameters. Water Res. 2005, 39, 3189-3198. [CrossRef]

41. Arslan-Alaton, I. The effect of pre-ozonation on the biocompatibility of reactive dye hydrolysates. Chemosphere 2003, 51, 825-833. [CrossRef]

42. Chiang, Y.-P.; Liang, Y.-Y.; Chang, C.-N.; Chao, A.C. Differentiating ozone direct and indirect reactions on decomposition of humic substances. Chemosphere 2006, 65, 2395-2400. [CrossRef] [PubMed]

43. Nakano, Y.; Okawa, K.; Nishijima, W.; Okada, M. Ozone decomposition of hazardous chemical substance in organic solvents. Water Res. 2003, 37, 2595-2598. [CrossRef]

44. Tsai, T.-Y.; Okawa, K.; Nakano, Y.; Nishijima, W.; Okada, M. Decomposition of trichloroethylene and 2,4-dichlorophenol by ozonation in several organic solvents. Chemospehere 2004, 57, 1151-1155. [CrossRef]

45. Kasprzyk-Hordern, B. Catalytic ozonation and methods of enhancing molecular ozone reactions in water treatment. Appl. Catal. B Environ. 2003, 46, 639-669. [CrossRef]

46. Camel, V.; Bermond, A. The use of ozone and associated oxidation processes in drinking water treatment. Review article. Water Res. 1998, 32, 3208-3222. [CrossRef]

47. Von Gunten, U. Ozonation of drinking water: Part I. Oxidation kinetics and product formation. Water Res. 2003, 37, 1443-1467. [CrossRef]

48. Audenaert, W.T.M.; Callewaert, M.; Nopens, I.; Cromphout, J.; Vanhoucke, R.; Dumoulin, A.; Dejans, P.; Van Hulle, S.W.H Full-scale modelling of an ozone reactor for drinking water treatment. Chem. Eng. J. 2010, 157, 551-557. [CrossRef]

49. Beltrán, F.J. Ozone Reaction Kinetics for Water and Wastewater System; Lewis Publishers: Boca Raton, FL, USA, 2004; ISBN 9781135463076. [CrossRef]

50. Soares, A.; Guieyesse, B.; Jefferson, B.; Cartmell, E.; Lester, J.N. Nonylphenol in the environment: A critical review on occurrence, toxicity and treatment in wastewaters. Environ. Int. 2008, 34, 1033-1049. [CrossRef]

51. Oller, I.; Malato, S.; Sánchez-Pérez, J.A. Combination of Advanced Oxidation Processes and biological treatments for wastewater decontamination-A review. Sci. Total Environ. 2009, 409, 4141-4166. [CrossRef]

52. Žgajnar Gotvajn, A.; Zagorc-Koncan, J.; Derco, J.; Almásiová, B.; Kassai, A. Oxidative Pretreatment of Fresh and Mature Landfill Leachate. J. Adv. Oxid. Technol. 2009, 12,71-80. [CrossRef]

53. Kralchevska, R.; Premru, A.; Tišler, T.; Milanova, M.; Todorovsky, D.; Pintar, A. UV-and visible-light assisted photocatalytic oxidation of a pesticide over $\mathrm{TiO}_{2}$ catalysts modified with neodymium and nitrogen. In Proceedings of the CD ROM of Full Texts of 19th International Congress of Chemical and Process Engineering CHISA, Prague, Czech Republic, 28 August-1 September 2010.

54. Gogate, P.R.; Pandit, A.B. A review of imperative technologies for wastewater treatment I: Oxidation technologies at ambient conditions. Adv. Environ. Res. 2004, 8, 501-551. [CrossRef]

55. Schaar, H.; Clara, M.; Gans, O.; Kreuzinger, N. Micropollutant removal during biological wastewater treatment and a subsequent ozonation step. Environ. Pollut. 2010, 158, 1399-1404. [CrossRef] [PubMed]

56. Ibáňez, M.; Gracia-Lor, E.; Bijlsma, L.; Morales, E.; Pastor, L.; Hernández, F. Removal of emerging contaminants in sewage water subjected to advanced oxidation with ozone. J. Hazard. Mater. 2013, 260, 389-398. [CrossRef]

57. Grandclément, C.; Seyssiecq, I.; Piram, A.; Wong-Wah-Chung, P.; Vanot, G.; Tiliacos, N.; Roche, N.; Doumenq, P. From the conventional biological wastewater treatment to hybrid processes, the evaluation of organic micropollutant removal: A review. Water Res. 2017, 111, 297-317. [CrossRef]

58. Lopez, A.; Ricco, G.; Mascolo, G.; Tiravanti, G.; Di Pinto, A.C.; Passino, R. Biodegradability enhancement of refractory pollutants by ozonation: A laboratory investigation on an azo-dyes intermediate. Water Sci. Technol. 1998, 38, 239-245. [CrossRef]

59. Ledakowicz, S.; Solecka, M. Biodegradation of textile wastewater. Inz. Chem. Proces. 1999, 20, 157-175.

60. Ledakowicz, S.; Miller, J.S.; Olejnik, D. Oxidation of PAHs in water solutions by ultraviolet radiation combined with hydrogen peroxide. Int. J. Photoenergy 1999, 1, 55-60. [CrossRef]

61. Greenens, D.; Bixio, B.; Thoeye, C. Combined ozone-activated sludge treatment of landfill leachate. Water Sci. Technol. 2001, 44, 359-365. [CrossRef]

62. Zenaitis, M.G.; Sandhu, H.; Duff, S.J.B. Combined biological and ozone treatment of log yard run-off. Water Res. 2002, 36, 2053-2061. [CrossRef]

63. Boncz, M.A.; Bruning, H.; Rulkens, W.H. Innovative reactor technology for selective oxidation of toxic organic pollutants in wastewater by ozone. Water Sci. Technol. 2003, 47, 17-24. [CrossRef]

64. Chaturapruek, A.; Visvanathan, C.; Ahn, K.-H. Ozonation of Membrane Bioreactor Effluent for Landfill Leachate Treatment. Environ. Technol. 2005, 26, 65-73. [CrossRef]

65. Tizaoui, C.; Bouselmi, L.; Mansouri, L.; Ghrabi, A. Landfill leachate treatment with ozone and ozone/hydrogen peroxide systems. J. Hazard. Mater. 2007, 140, 316-324. [CrossRef] [PubMed] 
66. Bila, D.M.; Montalvão, A.F.; Silva, A.C.; Dezotti, M. Ozonation of a landfill leachate: Evaluation of toxicity removal and biodegradability improvement. J. Hazard. Mater. 2005, 117, 235-242. [CrossRef]

67. Kurniawan, T.A.; Lo, W.; Chan, G.Y.S. Physico-chemical treatments for removal of recalcitrant contaminants from landfill leachate. J. Hazard. Mater. 2005, 129, 80-100. [CrossRef] [PubMed]

68. Derco, J.; Gulyásová, A.; Horňák, M. Influence of Ozonation on Biodegradability of Refractory Organics in a Landfill Leachate. Chem. Pap. 2002, 56, 41-44.

69. Poelmans, S.; Nagels, M.; Mignot, M.; Dewil, R.; Cabooter, D.; Dries, J. Effect of ozonation as pre-treatment and polishing step on removal of ecotoxicity and alkylphenol ethoxylates from tank truck cleaning wastewater. J. Water Process Eng. 2020, $37,101441$. [CrossRef]

70. Park, K.-Y.; Choi, S.-C.; Lee, S.-H.; Kweon, J.-H.; Song, J.-H. Comparison of formation of disinfection by-products by chlorination and ozonation of wastewater effluents and their toxicity to Daphnia magna. Environ. Pollut. 2016, 215, 314-321. [CrossRef] [PubMed]

71. Wu, Q.-Y.; Zhou, Y.-T.; Li, W.; Zhang, X.; Du, Y.; Hu, H.-Y. Underestimated risk from ozonation of wastewater containing bromide: Both organic byproducts and bromate contributed to the toxicity increase. Water Res. 2019, 162, 43-52. [CrossRef] [PubMed]

72. Kharel, S.; Stapf, M.; Miehe, U.; Ekblad, M.; Cimbritz, M.; Falas, P.; Nilsson, J.; Sehlén, R.; Bester, K. Ozone dose dependent formation and removal of ozonation products of pharmaceuticals in pilot and full-scale municipal wastewater treatment plants. Sci. Total Environ. 2020, 731, 139064. [CrossRef]

73. Nie, Y.; Qiang, Z.; Zhang, H.; Ben, W. Fate and seasonal variation of endocrine-disrupting chemicals in a sewage treatment plant with A/A/O process. Sep. Purif. Technol. 2012, 84, 9-15. [CrossRef]

74. Deblonde, T.; Cossu-Leguille, T.C.; Hartemann, P. Emerging pollutants in wastewater: A review of the literature. Int. J. Hyg. Environ. Health 2011, 214, 442-448. [CrossRef] [PubMed]

75. Hollender, J.; Escher, B. Eliminating micropollutants: Efficiency assessment. EAWAG News 2009, 67e, 28-30.

76. Zhang, J.; Zhang, J.; Tian, Y.; Li, N.; Kong, L.; Sun, L.; Yu, M.; Zuo, W. Changes of physicochemical properties of sewage sludge during ozonation treatment: Correlation to sludge dewaterability. Chem. Eng. J. 2016, 301, 238-248. [CrossRef]

77. Braguglia, C.M.; Gagliano, M.C.; Rossetti, S. High frequency ultrasound pretreatment for sludge anaerobic digestion: Effect on floc structure and microbial population. Bioresour. Technol. 2012, 110, 43-49. [CrossRef] [PubMed]

78. Saktaywin, W.; Tsuno, H.; Nagare, H.; Soyama, T.; Weerapakkaroon, J. Advanced sewage treatment process with excess sludge reduction and phosphorus recovery. Water Res. 2005, 39, 902-910. [CrossRef]

79. Yan, S.-T.; Zheng, H.; Li, A.; Zhang, X.; Xing, X.-H.; Chu, L.-B.; Ding, G.; Sun, X.-L.; Jurcik, B. Systematic analysis of biochemical performance and the microbial community of an activated sludge process using ozone-treated sludge for sludge reduction. Bioresour. Technol. 2009, 100, 5002-5009. [CrossRef]

80. Zhang, G.; Yang, J.; Liu, H.; Zhang, J. Sludge ozonation: Disintegration, supernatant changes and mechanisms. Bioresour. Technol. 2009, 100, 1505-1509. [CrossRef]

81. Babatunde, A.O.; Zhao, Y.Q. Constructive Approaches toward Water Treatment Works Sludge Management: An International Review of Beneficial Reuses. Crit. Rev. Environ. Sci. Technol. 2006, 37, 129-164. [CrossRef]

82. Cui, R.; Jahng, D. Nitrogen control in AO process with recirculation of solubilized excess sludge. Water Res. 2004, 38, 1159-1172. [CrossRef]

83. Boševski, I.; Žgajnar Gotvajn, A. The impact of single step ozonation of antibiotics-contaminated waste sludge to biogas production. Chemosphere 2021, 271, 1-8. [CrossRef]

84. Müller, J.A. Pretreatment processes for the recycling and reuse of sewage sludge. Water Sci. Technol. 2000, 42, 167-174. [CrossRef]

85. Park, K.Y.; Ahn, K.-H.; Maeng, S.K.; Hwang, J.H.; Kwon, J.H. Feasibility of sludge ozonation for stabilization and conditioning. Ozone Sci. Eng. 2003, 25, 73-80. [CrossRef]

86. Wang, Q.; Wei, W.; Gong, Y.; Yu, Q.; Li, Q.; Sun, J.; Yuan, Z. Technologies for reducing sludge production in wastewater treatment plants: State of the art. Sci. Total Environ. 2017, 587-588, 510-521. [CrossRef]

87. Kosowski, P.; Szostek, M.; Pieniążek, R.; Antos, P.; Skrobacz, K.; Piechowiak, T.; Żaczek, A.; Józefczyk, R.; Balawejder, M. New Approach for Sewage Sludge Stabilization with Ozone. Sustainability 2020, 12, 886. [CrossRef]

88. Marce, M.; Palacios, O.; Bartolomé, A.; Caicach, J.; Baig, S.; Esplugas, S. Application of Ozone on Activated Sludge: Micropollutant Removal and Sludge Quality. Ozone Sci. Eng. 2017, 39, 319-332. [CrossRef]

89. Xu, H.-L.; Tay, J.-H. Anaerobic granulation with methanol-cultured seed sludge. J. Environ. Sci. Health Part A Toxic/Hazard. Subst. Environ. Eng. 2002, 37, 85-94. [CrossRef] [PubMed]

90. Ried, A.; Mielcke, J.; Wieland, A.; Schaefer, S.; Sievers, M. An overview of the integration of ozone systems in biological treatment steps. Water Sci. Technol. 2007, 55, 253-258. [CrossRef]

91. Derco, J.; Melicher, M.; Kassai, A. Removal of Selected Benzothiazoles with Ozone. In Municipal and Industrial Waste Disposal; Intech: Rijeka, Croatia, 2012; pp. 135-160. ISBN 978-953-51-0501-5.

92. Gu, L.; Zhang, X.; Lei, L.; Liu, X. Concurrent removal of humic acid and o-dichlorobenzene in drinking water by combined ozonation and bentonite coagulation process. Water Sci. Technol. 2009, 60, 3061-3068. [CrossRef]

93. Chys, M.; Demeestere, K.; Ingabire, A.S.; Dries, J.; van Langenhove, H.; van Hulle, S.W.H. Enhanced treatment of secondary municipal wastewater effluent: Comparing (biological) filtration and ozonation in view of micropollutant removal, unselective effluent toxicity, and the potential for real-time control. Water Sci. Technol. 2017, 76, 236-246. [CrossRef] 
94. Hollender, J. Cytostatics in the Aquatic Environment: Analysis, Occurrence, and Possibilities for Removal; No. RWTH-CONV-114084; Lehrstuhl für Hygiene und Umweltmedizin: Aachen, Germany, 2009.

95. Stalter, D.; Magdeburg, A.; Oehlmann, J. Comparative toxicity assessment of ozone and activated carbon treated sewage effluents using an in vivo test battery. Water Res. 2010, 44, 2610-2620. [CrossRef] [PubMed]

96. Wang, S.; Ma, J.; Liu, B.; Jiang, Y.; Zhang, H. Degradation characteristics of secondary effluent of domestic wastewater by combined process of ozonation and biofiltration. J. Hazard. Mater. 2008, 150, 109-114. [CrossRef] [PubMed]

97. Bernal-Martínez, A.; Carrère, H.; Patureau, D.; Delgenès, J.P. Combining anaerobic digestion and ozonation to remove PAH from urban sludge. Process Biochem. 2005, 40, 3244-3250. [CrossRef]

98. Vranitzky, R.; Lahnsteiner, J. Ozone treatment of organic micro-pollutants in sewage sludge. Water Sci. Technol. 2010, 61, 2923-2930. [CrossRef]

99. Ak, M.S.; Muz, M.; Komseli, O.T.; Gökçay, C.F. Enhancement of bio-gas production and xenobiotics degradation during anaerobic sludge digestion by ozone treated feed sludge. Chem. Eng. J. 2013, 230, 499-505. [CrossRef]

100. Nie, Y.; Qiang, Z.; Ben, W.; Liu, J. Removal of endocrine-disrupting chemicals and conventional pollutants in a continuousoperating activated sludge process integrated with ozonation for excess sludge reduction. Chemosphere 2014, 105, 133-138. [CrossRef] [PubMed]

101. Bundschuh, M. The Challenge: Chemical and ecotoxicological characterization of wastewater treatment plant effluents. Environ. Toxicol. Chem. 2014, 33, 2407. [CrossRef] [PubMed]

102. Huber, M.M.; GÖbel, A.; Joss, A.; Hermann, N.; LÖffler, D.; McArdell, C.S.; Ried, A.; Siegrist, H.; Ternes, T.A.; von Gunten, U. Oxidation of Pharmaceuticals during Ozonation of Municipal Wastewater Effluents: A Pilot Study. Environ. Sci. Technol. 2005, 39, 4290-4299. [CrossRef] [PubMed]

103. Ternes, T.A.; Stüber, J.; Herrmann, N.; McDowell, D.; Ried, A.; Kampmann, M.; Teiser, B. Ozonation: A tool for removal of pharmaceuticals, contrast media and musk fragrances from wastewater? Water Res. 2003, 37, 1976-1982. [CrossRef]

104. Wert, E.C.; Rosario-Ortiz, F.L.; Snyder, S.A. Using ultraviolet absorbance and color to assess pharmaceutical oxidation during ozonation of wastewater. Environ. Sci. Technol. 2009, 43, 4858-4863. [CrossRef]

105. Zucker, I.; Mamane, H.; Cikurel, H.; Jekel, M.; Hübner, U.; Avisar, D. A hybrid process of biofiltration of secondary effluent followed by ozonation and short soil aquifer treatment for water reuse. Water Res. 2015, 84, 315-322. [CrossRef]

106. Zucker, I.; Lester, Y.; Avisar, D.; Hübner, U.; Jekel, M.; Weinberger, Y.; Mamane, H. Influence of Wastewater Particles on Ozone Degradation of Trace Organic Contaminants. Environ. Sci. Technol. 2015, 49, 301-308. [CrossRef] [PubMed]

107. Zagorc-Koncan, J.; Derco, J.; Žgajnar Gotvajn, A. Applicability of Fenton's reactions in treatment of fresh and mature landfill leachate. In Proceedings of the XIth International Waste Management and Landfill Symposium, S. Margheritadi Pula, Cagliari, Sardinia, Italy, 1-5 October 2007; pp. 695-696.

108. Bertanza, G.; Pedrazzani, R.; Papa, M.; Mazzoleni, G.; Steimberg, N.; Caimi, L.; Montani, C.; Dilorenzo, D. Removal of BPA and NPnEOs from Secondary Effluents of Municipal WWTPs by Means of Ozonation. Ozone Sci. Eng. 2009, 32, 204-208. [CrossRef]

109. Rodríguez, A.; Muñoz, I.; Perdigón-Melón, J.A.; Carbajo, J.B.; Martínez-Bueno, M.J.; Fernández-Alba, A.R.; García-Calvo, E.; Rosal, R. Environmental optimization of continuous flow ozonation for urban wastewater reclamation. Sci. Total Environ. 2012, 437, 68-75. [CrossRef]

110. Suarez, S.; Dodd, M.C.; Omil, F.; von Gunten, U. Kinetics of triclosan oxidation by aqueous ozone and consequent loss of antibacterial activity: Relevance to municipal wastewater ozonation. Water Res. 2007, 41, 2481-2490. [CrossRef] [PubMed]

111. Chys, M.; Audenaert, W.T.M.; Vangrinsven, J.; Bauwens, M.; Mortier, S.T.F.C.; Van Langenhove, H.; Nopens, I.; Demesteere, K.; Van Hulle, S.W.H. Dynamic validation of online applied and surrogate-based models for tertiary ozonation on pilot-scale. Chemosphere 2018, 196, 494-501. [CrossRef] [PubMed]

112. Chys, M.; Demesteere, K.; Nopens, I.; Audenaert, W.T.M.; Van Hulle, S.W.H. Municipal wastewater effluent characterization and variability analysis in view of an ozone dose control strategy during tertiary treatment: The status in Belgium. Sci. Total Environ. 2018, 625, 1198-1207. [CrossRef] [PubMed]

113. Rivas, J.; Gimeno, O.; Beltrán, F. Wastewater recycling: Application of ozone based treatments to secondary effluents. Chemosphere 2009, 74, 854-859. [CrossRef] [PubMed]

114. Balbanič, D.; Hermosilla, D.; Merayo, N.; Krivograd Klemenčič, A.; Blanco, Á. Comparison of different wastewater treatments for removal of selected endocrine-disruptors from paper mill wastewaters. J. Environ. Sci. Health Part A 2012, 47, 1350-1363. [CrossRef] [PubMed]

115. Zimmermann, S.G.; Wittenwiler, M.; Hollender, J.; Krauss, M.; Ort, C.; Siegrist, H.; von Gunten, U. Kinetic assessment and modeling of an ozonation step for full-scale municipal wastewater treatment: Micropollutant oxidation, by-product formation and disinfection. Water Res. 2011, 45, 605-617. [CrossRef]

116. Zucker, I.; Avisar, D.; Mamane, H.; Jekel, M.; Hübner, U. Determination of oxidant exposure during ozonation of secondary effluent to predict contaminant removal. Water Res. 2016, 100, 508-516. [CrossRef]

117. Lopez, A.; Benbelkacem, H.; Pic, J.-S.; Debellefontaine, H. Oxidation Pathways for Ozonation of Azo Dyes in a Semi-Batch Reactor: A Kinetic Parameters Approach. Environ. Technol. 2004, 25, 311-321. [CrossRef] [PubMed]

118. Rodriguez, E.M.; Fernandez, G.; Klamerth, N.; Maldonado, M.I.; Alvarez, P.M.; Malato, S. Efficiency of different solar advanced oxidation processes on the oxidation of bisphenol A in water. Appl. Catal. B Environ. 2010, 95, 228-237. [CrossRef] 
119. Lee, C.O.; Howe, K.J.; Thomson, B.M. Ozone and biofiltration as an alternative to reverse osmosis for removing PPCPs and micropollutants from treated wastewater. Water Res. 2012, 46, 1005-1014. [CrossRef]

120. Žgajnar-Gotvajn, A.; Zagorc-Končan, J.; Derco, J. Optimisation of Fenton process for the pretreatment of heavily polluted industrial landfill leachate. In Proceedings of the Conference: Wastewater 2006, Tatranské Zruby, Slovakia, 18-20 October 2006.

121. Andreozzi, R.; Caprio, V.; Insola, A.; Marotta, R. Advanced oxidation processes (AOP) for water purification and recovery. Catal Today 1999, 53, 51-59. [CrossRef]

122. Ormad, M.P.; Miguel, N.; Claver, A.; Matesanz, J.M.; Ovelleiro, J.L. Pesticides removal in the process of drinking water production. Chemosphere 2008, 4, 97-106. [CrossRef]

123. Ormad, M.P.; Miguel, N.; Lanao, M.; Mosteo, R.; Ovelleiro, J.L. Effect of Application of Ozone and Ozone Combined with Hydrogen Peroxide and Titanium Dioxide in the Removal of Pesticides from Water. Ozone Sci. Eng. 2010, 32, 25-32. [CrossRef]

124. Žgajnar Gotvajn, A.; Derco, J.; Vrabel', M.; Kassai, A. Improvement of biotreatability of environmentally persistent antibiotic Tiamulin by $\mathrm{O}_{3}$ and $\mathrm{O}_{3} / \mathrm{H}_{2} \mathrm{O}_{2}$ oxidation processes. Environ. Technol. 2021. [CrossRef]

125. Psaltou, S.; Zouboulis, A. Catalytic Ozonation and Membrane Contactors-A Review Concerning Fouling Occurrence and Pollutant Removal. Water 2020, 12, 2964. [CrossRef]

126. Ribeiro, A.R.; Moreira, N.F.F.; Puma, G.L.; Silva, A.M.T. Impact of water matrix on the removal of micropollutants by advanced oxidation technologies. Chem. Eng. J. 2019, 363, 155-173. [CrossRef]

127. Wang, J.; Tian, Z.; Huo, Y.; Yang, M.; Zheng, X.; Zhang, Y. Monitoring of 943 organic micropollutants in wastewater from municipal wastewater treatment plants with secondary and advanced treatment processes. J. Environ. Sci. 2018, 67, 309-317. [CrossRef]

128. Macova, M.; Escher, B.I.; Reungoat, J.; Carswell, S.; Chue, K.L.; Keller, J.; Mueller, J.F. Monitoring the biological activity of micropollutants during advanced wastewater treatment with ozonation and activated carbon filtration. Water Res. 2010, 44, 477-492. [CrossRef]

129. Sánchez-Polo, M.; Salhi, E.; Rivera-Utrilla, J.; von Gunten, U. Combination of Ozone with Activated Carbon as an Alternative to Conventional Advanced Oxidation Processes. Ozone Sci. Eng. 2006, 28, 237-245. [CrossRef]

130. Comninellis, C.; Kapalka, A.; Malato, S.; Parsons, S.A.; Poulios, I.; Mantzavinos, D. Advanced oxidation processes for water treatment: Advances and trends for R\&D. J. Chem. Technol. Biotechnol. 2008, 83, 769-776. [CrossRef]

131. Bui, X.T.; Vo, T.P.T.; Ngo, H.H.; Guo, W.S.; Nguyen, T.T. Multicriteria assessment of advanced treatment technologies for micropollutants removal at large-scale applications. Sci. Total Environ. 2016, 563-564, 1050-1067. [CrossRef]

132. Jin, X.; Peldszus, S.; Huck, P.M. Reaction kinetics of selected micropollutants in ozonation and advanced oxidation processes. Water Res. 2012, 46, 6519-6530. [CrossRef]

133. Hoigné, J.; Bader, H. The role of hydroxyl radical reactions in ozonation processes in aqueous solutions. Water Res. 1976, 10, 377-386. [CrossRef]

134. Bader, H.; Hoigné, J. Determination of ozone in water by the indigo method. Water Res. 1981, 15, 449-456. [CrossRef]

135. Kuosa, M. Modeling Reaction Kinetics and Mass Transfer in Ozonation in Water Solutions. Ph.D. Thesis, Lappeenranta University of Technology, Lappeenranta, Finland, 2018.

136. Beltrán, F.J.; García-Araya, J.F.; Acedo, B. Advanced oxidation of atrazine in water-I. Ozonation. Water Res. 1994, $28,2153-2164$. [CrossRef]

137. Begum, A.; Gautam, S.K. Endosulfan and lindane degradation using ozonation. Environ. Technol. 2012, 33, 943-949. [CrossRef]

138. Almomani, F.; Shawaqfah, M.; Bhosale, R.; Kumar, A. Removal of emerging pharmaceuticals from wastewater by ozone-based advanced oxidation processes. Environ. Prog. Sustain. Energy 2016, 35. [CrossRef]

139. Usharani, R.K.; Muthukumar, M.; Kadirvelu, K. Effect of $\mathrm{pH}$ on the Degradation of Aqueous methylparathion in Wastewater by Ozonation. Int. J. Environ. Res. 2012, 6, 557-564. [CrossRef]

140. Staehelin, J.; Hoigné, J. Decomposition of ozone in water: Rate of initiation by hydroxide ions and hydrogen peroxide. Environ. Sci. Technol. 1982, 16, 676-681. [CrossRef]

141. Khuntia, S.; Sinha, M.K.; Saini, B. An approach to minimize the ozone loss in a series reactor: A case of peroxone process. J. Environ. Chem. Eng. 2018, 6, 6916-6922. [CrossRef]

142. Volk, C.; Roche, P.; Joret, J.-C.; Paillard, H. Comparison of the effect of ozone, ozone-hydrogen peroxide system and catalytic ozone on the biodegradable organic matter of a fulvic acid solution. Water Res. 1997, 31, 650-656. [CrossRef]

143. Merényi, G.; Lind, J.; Naumov, S.; von Sonntag, C. Reaction of Ozone with Hydrogen Peroxide (Peroxone Process): A Revision of Current Mechanistic Concepts Based on Thermokinetic and Quantum-Chemical Considerations. Environ. Sci. Technol. 2010, 44, 3505-3507. [CrossRef] [PubMed]

144. Catalkaya, E.; Kargi, F. Advanced Oxidation and Mineralization of Simazine Using Fenton's Reagent. J. Hazard. Mater. 2009, 168, 688-694. [CrossRef] [PubMed]

145. Qiang, Z.; Liu, C.; Dong, B.; Zhang, Y. Degradation mechanism of alachlor during direct ozonation and $\mathrm{O}_{3} / \mathrm{H}_{2} \mathrm{O}_{2}$ advanced oxidation process. Chemosphere 2010, 78, 517-526. [CrossRef] [PubMed]

146. Acero, J.L.; Stemmler, K.; von Gunten, U. Degradation Kinetics of Atrazine and Its Degradation Products with Ozone and OH Radicals: A Predictive Tool for Drinking Water Treatment. Environ. Sci. Technol. 2000, 34, 591-597. [CrossRef]

147. Wert, E.C.; Rosario-Ortiz, F.L.; Snyder, S.A. Effect of ozone exposure on the oxidation of trace organic contaminants in wastewater. Water Res. 2009, 43, 1005-1014. [CrossRef] 
148. Peyton, G.R.; Glaze, W.H. Destruction of pollutants in water with ozone in combination with ultraviolet radiation. 3. Photolysis of aqueous ozone. Environ. Sci. Technol. 1988, 22, 761-767. [CrossRef]

149. Gottschalk, C.; Libra, J.A.; Saupe, A. Ozonation of Water and Waste Water: A Practical Guide to Understanding Ozone and Its Applications, 2nd ed.; Wiley-VCH Verlag GmbH \& Co. KGaA: Weinheim, Germany, 2009; ISBN 978-3-527-31962-6.

150. Beduk, F.; Aydin, M.E.; Aydin, S. Degradation of Malathion and Parathion by Ozonation, Photolytic Ozonation, and Heterogeneous Catalytic Ozonation Processes. Clean Soil Air Water 2012, 40, 179-187. [CrossRef]

151. Abrile, M.G.; Fiasconaro, M.L.; Lovato, M.E. Optimization of Reactive Blue 19 dye removal using ozone and ozone/UV employing response surface methodology. SN Appl. Sci. 2020, 2, 995. [CrossRef]

152. Kumar, R.V.; Barbosa, M.O.; Ribeiro, A.R.; Morales-Torres, S.; Pereira, M.F.R.; Silva, A.M.T. Advanced oxidation technologies combined with direct contact membrane distillation for treatment of secondary municipal wastewater. Process Saf. Environ. Prot. 2020, 140, 111-123. [CrossRef]

153. Hassanshahi, N.; Karimi-Jashni, A. Comparison of photo-Fenton, $\mathrm{O}_{3} / \mathrm{H}_{2} \mathrm{O}_{2} / \mathrm{UV}$ and photocatalytic processes for the treatment of gray water. Ecotoxicol. Environ. Saf. 2018, 161, 683-690. [CrossRef] [PubMed]

154. Zangeneh, H.; Zinatizadeh, A.A.L.; Feizy, M. A comparative study on the performance of different advanced oxidation processes $\left(\mathrm{UV} / \mathrm{O}_{3} / \mathrm{H}_{2} \mathrm{O}_{2}\right)$ treating linear alkyl benzene (LAB) production plant's wastewater. J. Ind. Eng. Chem. 2014, 20, 1453-1461. [CrossRef]

155. Bavasso, I.; Poggi, C.; Petrucci, E. Enhanced degradation of paracetamol by combining UV with electrogenerated hydrogen peroxide and ozone. J. Water Process Eng. 2020, 34, 101102. [CrossRef]

156. Beltrán, F.J.; Rivas, F.J.; Montero-de-Espinosa, R. Iron type catalysts for the ozonation of oxalic acid in water. Water Res. 2005, 39, 3553-3564. [CrossRef] [PubMed]

157. Fontainer, V.; Farines, V.; Albet, J.; Baig, S.; Molinier, J. Study of catalyzed ozonation for advanced treatment of pulp and paper mill effluents. Water Res. 2006, 40, 303-310. [CrossRef]

158. Ma, J.; Graham, N.J.D. Degradation of atrazine by manganese-catalysed ozonation: Influence of humic substances. Water Res. 1999, 33, 785-793. [CrossRef]

159. Cooper, C.; Burch, R. An Investigation of Catalytic Ozonation for the Oxidation of Halocarbons in Drinking Water Preparation. Water Res. 1999, 33, 3695-3700. [CrossRef]

160. Nawrocki, J.; Kasprzyk-Hordern, B. The efficiency and mechanisms of catalytic ozonation. Appl. Catal. B Environ. 2010, 99, 27-42. [CrossRef]

161. Pines, D.S.; Reckhow, D.A. Effect of dissolved cobalt(II) on the ozonation of oxalic acid. Environ. Sci. Technol. 2002, 36, 4046-4051. [CrossRef]

162. Farré, M.J.; Franch, M.I.; Malato, S.; Ayllón, J.A.; Peral, J.; Domènech, X. Degradation of some biorecalcitrant pesticides by homogeneous and heterogeneous photocatalytic ozonation. Chemosphere 2005, 58, 1127-1133. [CrossRef] [PubMed]

163. Psaltou, S.; Karapatis, A.; Mitrakas, M.; Zouboulis, A. The role of metal ions on p-CBA degradation by catalytic ozonation. J. Environ. Chem. Eng. 2019, 7, 103324. [CrossRef]

164. Kidak, R.; Dogan, S. Medium-high frequency ultrasound and ozone based advanced oxidation for amoxicillin removal in water. Ultrason. Sonochem. 2018, 40, 131-139. [CrossRef]

165. Zhang, T.; Ma, J. Catalytic ozonation of trace nitrobenzene in water with synthetic goethite. J. Mol. Catal. A Chem. 2008, 279, 82-89. [CrossRef]

166. Huang, R.; Lan, B.; Chen, Z.; Yan, H.; Zhang, Q.; Bing, J.; Li, L. Catalytic ozonation of p-chlorobenzoic acid over MCM-41 and Fe loaded MCM-41. Chem. Eng. J. 2012, 180, 19-24. [CrossRef]

167. Liu, X.; Zhou, Z.; Jing, G.; Fang, J. Catalytic ozonation of Acid Red B in aqueous solution over a Fe-Cu-O catalyst. Sep. Purif. Technol. 2013, 115, 129-135. [CrossRef]

168. Lan, B.; Huang, R.; Li, L.; Yan, H.; Liao, G.; Wang, X.; Zhang, Q. Catalytic ozonation of p-chlorobenzoic acid in aqueous solution using Fe-MCM-41 as catalyst. Chem. Eng. J. 2013, 219, 346-354. [CrossRef]

169. Gopi, T.; Swetha, G.; Chandra Shekar, S.; Krishna, R.; Ramakrishna, C.; Saini, B.; Rao, P.V.L. Ozone catalytic oxidation of toluene over 13X zeolite supported metal oxides and the effect of moisture on the catalytic process. Arab. J. Chem. 2019, 12, 4502-4513. [CrossRef]

170. Larouk, S.; Ouargli, R.; Shahidi, D.; Olhund, L.; Shiao, T.C.; Chergui, N.; Sehili, T.; Roy, R.; Azzouz, A. Catalytic ozonation of Orange-G through highly interactive contributions of hematite and SBA-16-To better understand azo-dye oxidation in nature. Chemosphere 2017, 168, 1648-1657. [CrossRef] [PubMed]

171. Fujita, H.; Izumi, J.; Sagehashi, M.; Fujii, T.; Sakoda, A. Adsorption and decomposition of water-dissolved ozone on high silica zeolites. Water Res. 2004, 38, 159-165. [CrossRef]

172. Valdés, H.; Farfán, V.J.; Manoli, J.A.; Zaror, C.A. Catalytic ozone aqueous decomposition promoted by natural zeolite and volcanic sand. J. Hazard. Mater. 2009, 165, 915-922. [CrossRef]

173. Valdés, H.; Zaror, C.A. Heterogeneous and homogeneous catalytic ozonation of benzothiazole promoted by activated carbon: Kinetic approach. Chemosphere 2006, 65, 1131-1136. [CrossRef] [PubMed]

174. Qu, X.; Zheng, J.; Zhang, Y. Catalytic ozonation of phenolic wastewater with activated carbon fiber in a fluid bed reactor. J. Colloid Interface Sci. 2007, 309, 429-434. [CrossRef] 
175. Xing, L.; Xie, Y.; Minakata, D.; Cao, H.; Xiao, J.; Crittenden, J.C. Activated carbon enhanced ozonation of oxalate attributed to HO oxidation in bulk solution and surface oxidation: Effect of activated carbon dosage and pH. J. Environ. Sci. 2014, 26, $2095-2105$. [CrossRef]

176. Gümüş, D.; Akbal, F. A comparative study of ozonation, iron coated zeolite catalyzed ozonation and granular activated carbon catalyzed ozonation of humic acid. Chemosphere 2017, 174, 218-231. [CrossRef]

177. Derco, J.; Melicher, M.; Dudáš, J.; Kecskés, J. Investigation of ozone based processes for removal of benzothiazoles. In Proceedings of the IOA World Congress 2015 on Ozone and Advanced Oxidation Leading-Edge Science and Technologies, Barcelona, Spain, 28 June-3 July 2015; ISBN 979-10-92607-02-4.

178. Sui, M.; Sheng, L.; Lu, K.; Tian, F. FeOOH catalytic ozonation of oxalic acid and the effect of phospate binding on its catalytic activity. Appl. Catal. B Environ. 2010, 96, 94-100. [CrossRef]

179. Leitner, N.K.V.; Delanoe, F.; Acedo, B.; Legube, B. Reactivity of various $\mathrm{Ru} / \mathrm{CeO}_{2}$ catalysts during ozonation of succinic acid aqueous solutions. New J. Chem. 2000, 24, 229-233. [CrossRef]

180. Legube, B.; Vel Leitner, N.K. Catalytic ozonation: A promising advanced oxidation technology for water treatment. Catal. Today 1999, 53, 61-72. [CrossRef]

181. Dang, T.T.; Manh, D.V.; Tuyen, T.V. Nano-Catalysts in Ozone-Based Advanced Oxidation Processes for Wastewater Treatment. Curr. Pollut. Rep. 2020, 6, 217-229. [CrossRef]

182. Lu, H.; Wang, J.; Stoller, M.; Wang, T.; Bao, Y. An overview of nanomaterials for water and wastewater treatment. Adv. Mater. Sci. Eng. 2016, 2016, 4964828. [CrossRef]

183. Lekota, M.W.; Dimpe, K.M.; Nomngongo, P.N. MgO-ZnO/carbon nanofiber nanocomposite as an adsorbent for ultrasoundassisted dispersive solid-phase microextraction of carbamazepine from wastewater prior to high-performance liquid chromatographic detection. J. Anal. Sci. Technol. 2019, 10. [CrossRef]

184. Mahadik, S. Applications of nanotechnology in water and waste water treatment. AADYA-J. Manag. Technol. 2017, 7, 187-191.

185. Carbajo, J.B.; Petre, A.L.; Rosal, R.; Berná, A.; Letón, P.; García-Calvo, E.; Perdigón-Melón, J.A. Ozonation as pre-treatment of activated sludge process of a wastewater containing benzalkonium chloride and $\mathrm{NiO}$ nanoparticles. Chem. Eng. J. 2016, 283, 740-749. [CrossRef]

186. Čehovin, M.; Medic, A.; Scheideler, J.; Mielcke, J.; Ried, A.; Kompare, B.; Žgajnar Gotvajn, A. Hydrodynamic cavitation in combination with the ozone, hydrogen peroxide and the UV-based advanced oxidation processes for the removal of natural organic matter from drinking water. Ultrason. Sonochem. 2017, 37, 394-404. [CrossRef] [PubMed]

187. Zhen, G.; Lu, X.; Kato, H.; Zhao, Y.; Li, Y.-Y. Overview of pretreatment strategies for enhancing sewage sludge disintegration and subsequent anaerobic digestion: Current advances, full-scale application and future perspectives. Renew. Sustain. Energy Rev. 2017, 69, 559-577. [CrossRef]

188. Derco, J.; Dudáš, J.; Valičková, M.; Šimovičová, K.; Murínová, S. Removal of alkylphenols from real wastewater using O3 and O3/GAC. In Proceedings of the 7th European Meeting on Chemical Industry and Environment, Tarragona, Spain, 10-12 June 2015; pp. 623-624, ISBN 978-84-8424-367-0.

189. Ning, B.; Graham, N.J.D.; Zhang, Y. Degradation of octylphenol and nonylphenol by ozone-Part I: Direct reaction. Chemosphere 2007, 68, 1163-1172. [CrossRef] [PubMed]

190. Ning, B.; Graham, N.J.D.; Zhang, Y. Degradation of octylphenol and nonylphenol by ozone-Part II: Indirect reaction. Chemosphere 2007, 68, 1173-1179. [CrossRef] [PubMed]

191. Derco, J.; Dudáš, J.; Valičková, M.; Sumegová, L.; Murínová, S. Removal of Alkylphenols from Industrial and Municipal Wastewater. Chem. Biochem. Eng. Q. 2017, 31, 173-178. [CrossRef]

192. Urminská, B.; Derco, J.; Šimkovič, K.; Devaux, A. Utilization of ozonation and adsorption ozonization in the treatment of industrial waste water containing alkylphenols (In Slovak). In Proceedings of the 10th Biennial Conference with the Inter-national Participation of Waste Water, Štrbské Pleso, Slovakia, 17-19 October 2018; Association of Wastewater Treatment Experts of the Slovak Republic: Bratislava, Slovakia, 2018; pp. 172-176, ISBN 978-84-8424-367-0.

193. Urminská, B.; Derco, J.; Bony, S.; Devaux, A.; Šimkovič, K.; Čižmárová, O. Use of ozonation and adsorptive ozonation for the industrial wastewater treatment. In Proceedings of the 46th International Conference of the Slovak Society of Chemical Engineering, Tatranské Matliare, Slovakia, 20-23 May 2019; Slovak Society of Chemical Engineering: Bratislava, Slovakia, 2019; p. 77.

194. Boehme, R.M.; Andries, T.; Dötz, K.H.; Thiele, B.; Guenther, K. Synthesis of defined endocrine-disrupting nonylphenol isomers for biological and environmental studies. Chemosphere 2010, 80, 813-821. [CrossRef] [PubMed]

195. Guenther, K.; Heinke, V.; Thiele, B.; Kleist, E.; Prast, H.; Raecker, T. Endocrine disrupting nonylphenols are ubiquitous in food. Environ. Sci. Technol. 2002, 36, 1676-1680. [CrossRef]

196. European Parliament, Council of the European Union. Directive 2003/53/EC of the European parliament and of the council of 18 June 2003 amending for the 26th time Council Directive 76/769/EEC relating to restrictions on the marketing and use of certain dangerous substances and preparations (nonylphenol, nonylphenol ethoxylate and cement). Off. J. Eur. Union 2003, L 178, 24-28.

197. U.S. Environmental Protection Agency. Nonylphenol (NP) and Nonylphenol Ethoxylates (NPEs) Action Plan; [RIN 2070-ZA09]; U.S. Environmental Protection Agency: Washington, DC, USA, 2010.

198. Dulov, A.; Dulova, N.; Trapido, M. Photochemical degradation of nonylphenol in aqueous solution: The impact of $\mathrm{pH}$ and hydroxyl radical promoters. J. Environ. Sci. 2013, 25, 1326-1330. [CrossRef] 
199. Narkis, N.; Schneider-Rotel, M. Evaluation of ozone induced biodegradability of wastewater treatment plant effluent. Water Res. 1980, 14, 929-939. [CrossRef]

200. Baig, S.; Hansmann, G.; Paolini, B. Ozone oxidation of oestrogenic active substances in wastewater and drinking water. Water Sci. Technol. 2008, 58, 451-458. [CrossRef]

201. Zhang, Y.; Zhou, X.; Lin, Y.; Zhang, X. Ozonation of nonylphenol and octylphenol in water. Fresenius Environ. Bull. 2008, 21, 731-735. [CrossRef]

202. Ahel, M.; Giger, W.; Koch, M. Behaviour of alkylphenol polyethoxylate surfactants in the aquatic environment-I. Occurrence and transformation in sewage treatment. Water Res. 1994, 28, 1131-1142. [CrossRef]

203. Bhandari, G.; Bagheri, A.R.; Bhatt, P.; Bilal, M. Occurrence, potential ecological risks, and degradation of endocrine disrupter, nonylphenol, from the aqueous environment. Chemosphere 2021, 275, 130013. [CrossRef]

204. Mohammadi, L.; Rahdar, A.; Bazrafshan, E.; Dahmardeh, H.; Susan, M.A.B.H.; Kyzas, G.Z. Petroleum Hydrocarbon Removal from Wastewaters: A Review. Processes 2020, 8, 447. [CrossRef]

205. Mota, A.L.N.; Albuquerque, L.F.; Beltrame, L.; Chiavone-Filho, O.; Machulek, A.; Nascimento, C.A.O. Advanced oxidation processes and their application in the petroleum industry: A review. Braz. J. Pet. Gas 2009, 2, 122-142. [CrossRef]

206. Wang, Z.D.; Brown, C.E. Environmental Forensic Investigation: Chapter 3: Chemical fingerprinting of petroleum hydrocarbons. In Methods in Environmental Forensics; CRC Press: New York, NY, USA, 2008; pp. 43-114. ISBN 9780849350078.

207. Mazzeo, D.E.C.; Levy, C.E.; de Angelis, D.; Marin-Morales, M.A. BTEX biodegradation by bacteria from effluents of petroleum refinery. Sci. Total Environ. 2010, 408, 4334-4340. [CrossRef] [PubMed]

208. Wiszniowski, J.; Ziembińska-Buczyńska, A.; Ciesielski, S. Effect of petroleum organic compounds in synthetic wastewater on treatment performance and microbial community structures in membrane biological reactor (MBR). J. Biotechnol. 2010, 150, 277-278. [CrossRef]

209. Sumegová, L.; Derco, J.; Šimovičová, K.; Luptáková, A.; Kecskés, J. Comparison of BTEX degradation with ozone based processes. In Proceedings of the 41st International Conference of Slovak Society of Chemical Engineering, Tatranské Matliare, Slovakia, 26-30 May 2014; AXIMA Graphic design and Printing Services: Bratislava, Slovakia, 2014; pp. 224-230, ISBN 978-80-89475-13-1.

210. Derco, J.; Dudáš, J.; Šilhárová, K.; Valičková, M.; Melicher, M.; Luptáková, A. Removal of Selected Micropollutants by Ozonation. In Proceedings of the Chemical Engineering Transactions: 15th Conference on Process Integration, Modelling and Optimisation for Energy Saving and Pollution Reduction, Prague, Czech Republic, 25-29 August 2012; pp. 1315-1320.

211. Derco, J.; Šimovičová, K.; Dudáš, J.; Valíčková, M. Removal of BTX Contaminants with O3 and O3/UV Processes. In PhysicoChemical Wastewater Treatment and Resource Recovery, 1st ed.; InTech: Rijeka, Croatia, 2017; pp. 3-18, ISBN 978-953-51-3129-8. [CrossRef]

212. Derco, J.; Králik, M.; Dudáš, J.; Balážová-Pijáková, I.; Šimovičová, K. The Prevention, Removal and Assessment of Oil Substances on Aquatic Environments. In Petroleum Refining and Oil Well Drilling: Problems, Processes and Industry Prospects, 1st ed.; Nova Science Publishers: New York, NY, USA, 2017; pp. 161-221, ISBN 978-1-53612-124-7.

213. Derco, J.; Valičková, M.; Šilhárová, K.; Dudáš, J.; Luptáková, A. Removal of selected chlorinated micropollutants by ozonation. Chem. Pap. 2013, 67, 1585-1593. [CrossRef]

214. Derco, J.; Dudáš, J.; Valičková, M.; Šimovičová, K.; Kecskés, J. Removal of micropollutants by ozone based processes. Chem. Eng. Process.-Process Intensif. 2015, 94, 78-84. [CrossRef]

215. Derco, J.; Dudáš, J.; Gotvajn Žgajnar, A.; Šimkovič, K.; Urminská, B. Removal of Selected Specific Substances by Ozone Based Processes. In Proceedings of the CUTTING Edge 2015, Scientific Conference, Ljubljana, Slovenia, 22 September 2015; Fakulteta za Kemijo in Kemijsko Tehnologijo: Ljubjana, Slovenia, 2015; ISBN 978-961-6756-62-4.

216. Derco, J.; Dudáš, J.; Valičková, M.; Šilhárová, K.; Sumegová, L. Removal of micropollutants by ozone-based processes. In Proceedings of the CHISA 2014-21st International Congress of Chemical and Process Engineering, Prague, Czech Republic, 23-27 August 2014; ISBN 978-80-02-02555-9.

217. Pannu, R.; Kumar, D. Process optimization of $\gamma$-Hexachlorocyclohexane degradation using three novel Bacillus sp. Strains. Biocatal. Agric. Biotechnol. 2017, 11, 97-107. [CrossRef]

218. Ikehata, K.; El-Din, M.K. Aqueous Pesticide Degradation by Ozonation and Ozone-Based Advanced Oxidation Processes: A Review (Part II). Ozone Sci. Eng. 2005, 27, 173-202. [CrossRef]

219. Jones, O.A.H.; Green, P.G.; Voulvoulis, J.N.L. Questioning the excessive use of advanced treatment to remove organic micropollutants from wastewater. Environ. Sci. Technol. 2007, 41, 5085-5089. [CrossRef]

220. Cases, V.; Alonso, V.; Argandoña, V.; Rodriguez, M.; Prats, D. Endocrine disrupting compounds: A comparison of removal between conventional activated sludge and membrane bioreactors. Desalination 2011, 272, 240-245. [CrossRef]

221. Felsot, A.S.; Racke, K.D.; Hamilton, D.J. Disposal and Degradation of Pesticide Waste. Rev. Environ. Contam. Toxicol. 2003, 177. [CrossRef]

222. Feakin, S.J.; Gubbins, B.; McGhee, I.; Shaw, L.J.; Burns, R.G. Inoculation of granular activated carbon with s-triazine-degrading bacteria for water treatment at pilot-scale. Water Res. 1995, 29, 1681-1688. [CrossRef]

223. Reynolds, G.; Graham, N.; Perry, R.; Rice, R.G. Aqueous Ozonation of Pesticides: A Review. Ozone Sci. Eng. 1989, 11, $339-382$. [CrossRef]

224. Wei, D.Y.; Jia, X.S.; Lu, G.Y.; Liu, G.L. Kinetics and mechanism analysis of the degradation of hexachlorbenzene in water by advanced oxidation process. Huan Jing Ke Xue 2008, 29, 1277-1283. (In Chinese) 
225. Vagi, M.C.; Petsas, A.S. Recent advances on the removal of priority organochlorine and organophosphorus biorecalcitrant pesticides defined by Directive 2013/39/EU from environmental matrices by using advanced oxidation processes: An overview (2007-2018). Engineering 2020, 8, 102940. [CrossRef]

226. Derco, J.; Valičková, M.; Šilhárová, K.; Dudáš, J.; Melicher, M.; Luptáková, A. Removal of selected micropollutants by ozonation. In Proceedings of the 39th International Conference of Slovak Society of Chemical Engineering, Tatranské Matliare, Bratislava, Slovakia, 21-25 May 2012; pp. 475-481, ISBN 978-80-89475-04-9.

227. Valičková, M.; Derco, J.; Šimovičová, K. Removal of selected pesticides by adsorption. Acta Chim. Slovaca 2013, 6, 25-28. [CrossRef] 